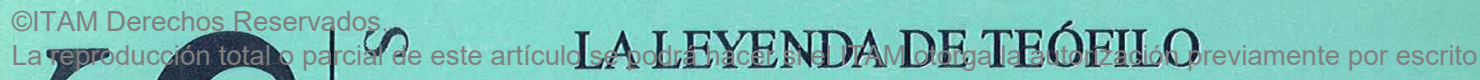

$\varangle$
$\simeq 4$
-1
-1
-1

Luis Astey

LA PROPUESTA AGRARIA DE

CARRANZA Y LOS SONORENSES

Manta García Ugante

ENTREVISTA A EDUARDO MILÁN

$\varangle$ Edruardo Aguilas

SEGURIDAD NACIONAL:

RELACIONES EE. UU. - MÉXICO

(1821-1867)

Ranil Figueroa

NOTAS DE : Enrique Aguayo, Émile Noulet, Ignacio Díaz de la Serna y Marcela Cinta.

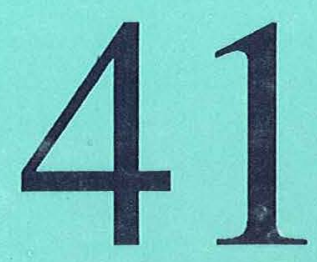

VERANO 1995

INSTITUTO TECNOLÓGICO AUTÓNOMO DE MÉXICO 


\section{E S T U D I O S}

FILOSOFÍA * HISTORIA * LETRAS

\section{1}

VERANO 1995

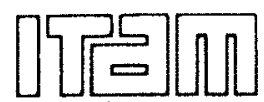




\section{E S T U D I O S}

\section{FILOSOFÍA * HISTORIA * LETRAS}

Publicación trimestral del Departamento Académico de Estudios Generales del Instituto Tecnológico Autónomo de México

$$
41
$$

VERANO 1995

\section{DIRECTOR}

Julián Meza

\section{JEFE DE REDACCIÓN}

Alberto Sauret

\section{SECRETARIO DE REDACCIÓN \\ Juan Carlos Geneyro}

ADMINISTRADOR

Patricio Sepúlveda

\section{CONSEJO EDITORIAL}

\section{Departamento Académico de Estudios Generales}

Margarita Aguilera, Luis Astey, José Barba, Ignacio Díaz de la Serna, Antonio Díez, Carlos de la Isla, Raúl Figueroa, Marta Eugenia Garcia Ugarte', Juan Carlos Mansur

Carlos McCadden, Milagros Mier, José Manuel Orozco, Julia Sierra, Reynaldo Sordo

\section{Departamento Académico de Estudios Internacionales}

Rafael Fernández de Castro, Blanca Heredia, Jesús Velasco, Stéphan Sberro

\section{Centro de Lenguas}

Claudia Albarrán, Antonio Canizales, Luz Elena Gutiérrez de Velasco, Nora Pasternac, María de Teresa de Zubiaurre 


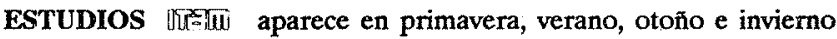

Precio por ejemplar: N\$20.00 M.N. D.F., Extranjero 10 dis.

Suscripclón anual (4 números): N\$ 70.00 M.N. en el D.F.

NS 80.00 M.N. interior de la República; 35 dls. en el extranjero

\section{Correspondencia:}

Instituto Tecnológico Autónomo de México

Departamento Académico de Estudios Generales

Río Honđo No. 1, Tizapán, San Angel

01000, México D.F.

Tels.: 6284000 exts. 3900 y 3903

\section{ISSN 0185-6383}

Licitud de titulo No. 2512

Licitud de contenido No. 1607

Diseño: Annie Hasselkus

Distribución: El Equilibrista - Centro de Distribución

Interamericano S.A. de C.V., Botticelli 52, Mixcoac, C.P. 03910.

México, D.F., Tels.: 5633140 Fax: 5638607

Tipografía en laser: Ma. Esther Sedano (ITAM)

Formación, negativos, impresión y acabado: Cuicatl Ediciones de México, S.A. de C.V.; Gral. Gómez Pedraza No. 13 San Miguel Chapultepec.

C.P. 11850 Tel. 2712239 y Fax 5532165. 


\section{ÍNDICE}

\section{TEXTOS}

LA LEYENDA DE TEÓFILO

Luis Astey

Respuesta

Manuel Alcalá

LA PROPUESTA AGRARIA DE VENUSTIANO CARRANZA Y LOS SONORENSES (1915-1929)

Marta Garcia Ugarte

ENTREVISTA A EDUARDO MILÁN

LA SEGURIDAD NACIONAL NORTEAMERICANA: LAS RESPUESTAS MEXICANAS (1821-1867)

\section{NOTAS}

EL CONCEPTO DE PERSONA EN LA FILOSOFÍA DE MAURICIO BEUCHOT 
ÍNDICE

EXÉGESIS DE UN POEMA DE MALLARMÉ Émile Noulet

NOTA SOBRE SCHILLER (LA HERENCIA LIBERAL Y ROMÁNTICA) Ignacio Díaz de la Serna JEAN GENET: COMEDIANTE Y MÁRTIR

\section{RESEÑAS}

LUIS ASTEY, Dramas Litúrgicos del Occidente Medieval Guillermo Schmidhuber de la Mora EDGARDO ENRÍQUEZ FRÖEDEN, En el nombre de una vida 


\section{LA LEYENDA DE TEÓFILO*}

Luis Astey**

1. Si, desbordando en cierta medida las acepciones que al respecto registra el Diccionario de la Real Academia Española en su edición más reciente, se acepta entender por tópico un área retórica definida pero vacía y susceptible de ser intelectual y emotivamente llenada conforme a la subjetividad de quien se lo proponga, este discurso de no merecido ingreso a la Academia Mexicana se halla constituido por tres tópicos fundamentales.

2. El primero se cumple, apropiadamente, con admiración y respeto. En efecto, Don Octaviano Valdés, nacido en 1901, fue ordenado presbítero a la edad de 26 años tras la correspondiente preparación en el Seminario Conciliar de la ciudad de México y en el Colegio Pío Latino y la Universidad Gregoriana de la ciudad de Roma -preparación que lo condujo a obtener los doctorados en Filosofía y en Teología; en 1951 fue designado canónigo de la Catedral Metropolitana en México y a partir de 1953 desempeñó varios cargos para el correspondiente Arzobispado: desde Vicecanciller Secretario de la Mitra hasta Protonotario Apostólico y Coordinador de ésta así como Vicario General de aquél (1978). En 1956 había recibido la dignidad de Prelado Doméstico de Su Santidad el Papa. Y ésá su brillante trayectoria en el orden de lo eclesiástico, sin duda causante de numerosas tareas administrativas, no le fue obstáculo sino al parecer estímulo tanto para su ejercicio de la convivencia y amistad

* Discurso leído por su autor el martes 7 de febrero de 1995 en la sede de la Academia Mexicana correspondiente de la Española, durante la ceremonia por la que fue incorporado a ésta como Miembro de Número. Al final se incluye la respuesta al discurso, a cargo del Mtro. Manuel Alcalá, miembro de dicha Academia.

** Departamento Académico de Estudios Generales, ITAM. 


\section{LUIS ASTEY}

-muestra de ello la "Tertulia dominical del Padre Valdés", de 1932 a 1991 semanalmente celebrada en su casa - como para su al mismo tiempo diversa y unitaria dedicación académica. Diversa en sus modos de manifestarse: poesía (El pozo de Jacob: 1933; Bajo el ala del ángel: 1952), novela (La cabellera de Berenice: 1968); ensayo (El prisma de Horacio: 1937; ángel María Garibay: 1985); traducción (Por los campos de México: 1942, 1950 y 1973); biografía relatada con técnica de novela (El padre Tembleque: 1945 y 1973); enseñanza (cátedras de Griego, de Filosofía y de Arte Sacro a lo largo de 35 años: 1929-1964), presencia (desde 1956) en esta corporación, de la que además fue séptimo censor. Son ejemplos. Dedicación unitaria, en cambio, por el espíritu que la presidió, continua y auténticamente religioso.

Dado ese curso de su vida y según las ideas de la fe que profesaba, hace casi ya cuatro años (murió el 29 de mayo de 1991) Don Octaviano Valdés debe de hallarse en perpetua felicidad y gloria. Que así sea.

3a. El segundo tópico, el que ha dado título al discurso, cae bajo la conocida y sabia sentencia del Qohélet (Eclesiastés en la Septuaginta y en otras traducciones): "Lo que fue, eso será y lo que ha sido hecho, eso será hecho, y nada hay nuevo bajo el sol" (I, 9), aun cuando, como ha de verse, en cierto sentido intenta eludirla. Admítase pasar a él.

3b. En su lengua de origen, el griego, de la leyenda de Teófilo, compuesta en la segunda mitad del siglo VII o ya en el VIII, se conservan, cada una con sus propias variantes, dos versiones. La más tardía y más extensa de ellas, que en los colofones de tres manuscritos se atribuye a sí mismo alguien que dice tener por nombre Eutiquiano y haber sido familiar del protagonista, clérigo y escribano en su iglesia y testigo presencial de los hechos, en el siglo IX fue traducida al latín por un diácono de Nápoles llamado a su vez Paulus, quien dirigió la obra a Carlos el Calvo, último de los emperadores carolingios. Con fundamento directo o indirecto en esa traducción, hasta el año de 1500 la leyenda conoció entonces difusión y amplio desarrollo en el ámbito cultural de Occidente. Así lo manifiestan, entre otros testimonios (plásticos algunos de ellos), variados y numerosos textos literarios narrativos o dramáticos o líricos, en prosa o en verso, escritos en la mayor parte de las lenguas ahí y entonces en uso: nuevamente latín, italiano, francés, español, galaicoportugués, anglosajón, inglés, holandés, bajo y alto alemán, islandés, sueco. Textos de los que, por diversas razones es preciso destacar por lo 
menos los siguientes. En latín, la quinta leyenda de Hrotsvitha de Gandersheim ("Caída y conversión del vicario Teófilo"), del siglo X, por ser la más antigua versificación del relato, e igualmente la sección en que éste es incorporado por el dominico genovés Jacobo de la Vorágine al capítulo 189 " "De la concepción de la bienaventurada virgen María": 8 de diciembre) de su Leyenda áurea (c. 1264), pues dado el propósito de recopilar y difundir lo más conocido a que ésta obedece, tal incorporación constituye la mejor prueba de la aceptación de aquél por el estrato eclesiástico. En francés, el Miracle de Théophile (1260) de Rutebeuf porque en su verso 653, aunque casi al final del drama y no en la voz del vicario sino en la de su obispo, se introduce por primera vez la idea, tan repetida posteriormente, de que el pacto con el Diablo es puesto por escrito con la propia sangre: "Lo escribió con su sangre, otra tinta no hizo entrar en él". Así como, sin que sea necesario especificar porqués en español el "Milagro de Teófilo" en los Milagros de Nuestra Señora (c. 1250?) de Gonzalo de Berceo, el 'Enjienplo de Theófilo' en el capítulo 82 ("Muestra cómo las mujeres de los reyes deben haber también [=tan bien] los bienes del alma como los del cuerpo") en la segunda redacción de los Castigos e documentos (c. 1292) del rey Sancho IV y la narración que bajo la máxima "Quien a la Virgen sirve con devoción / de sus pecados le gana el perdón" incluye Clemente Sánchez de Vercial en su Libro de los exenplos por A.B.C. (c. 1400-1421) más, en galaico-portugués, la tercera cantiga (1257?), "Como Santa Maria fez cobrar a Theophilo a carta que fezera como Demo, u se tornou seu vassalo", de Alfonso $\mathrm{X}$ el Sabio. Y, trascendiendo el término cronológico antes señalado, es asimismo indispensable poner de relieve un punto que desde las últimas décadas del siglo XIX ha sido reconocido en muchas ocasiones por especialistas en el tema (Th. Zahn: 1882, R. Petsch: 1908, C. Plenzat: 1926, L. Radermacher: 1927, PH. M. Palmer y R.P: More: 1936, por nombrar algunos): la relación histórico-literaria del Fausto de Goethe con la leyenda, que se halla testimoniada por la actancia en él de la Mater gloriosa como centro y culminación de "lo eterno femenino que nos atrae hacia lo alto" - actancia que, por otra parte, no se encuentra ni en el anónimo Libro popular del doctor Fausto que el impresor Johann Spies publicó en Frankfurt en 1587 y que fue el más difundido de los tratamientos iniciales del respectivo material ni en ninguna de las dos elaboracio- 


\section{LUIS ASTEY}

nes (1604 y 1616) de La trágica historia del doctor Fausto de Christopher Marlowe, primer drama de alto nivel que se ocupa de esa historia.

Tanto en trabajos de esos y de otros especialistas como en la introducción a cualquiera de las ediciones más o menos eruditas de todas las obras mencionadas, o de otras que desarrollan asuntos similares - El mágico prodigioso de Calderón de la Barca, por ejemplo-, es posible hallar datos y consideraciones acerca de la leyenda de Teófilo. De ordinario las mismas consideraciones y los mismos datos. Para evitar repetirlos una vez más, se sustituyen aquí por una traducción al español - tal vez la primera que se ha hecho- de la traducción de Paulus, cuya quizá todavía no agotada función seminal para una rama de la literatura de Occidente sí conviene en este momento reitèrar. Para dicha traducción al español se toma como base la edición del texto latino que ofrecen los Acta sanctorum de los Bolandistas (Febrero, vol. I, p. 483-489; Amberes, 1658), obra que, afortunadamente, se conserva en el Fondo de Origen de la Biblioteca Nacional de México.

\section{3c. De Teófilo arrepentido:}

un milagro de Santa María.

Autor: Eutiquiano.

\section{Traductor: Paulus, diácono de Nápoles.}

\section{Capítulo I}

Alejamiento de Teófilo de la vida virtuosa. Cristo y Santa María negados con juramento.

(1) Sucedió que, antes de que se realizase la incursión de la execrable raza de los persas en el estado romano, en una ciudad denominada Adana, perteneciente al segundo distrito de Cilicia, vivía un vicario de la santa iglesia de Dios, de nombre Teófilo, sobresaliente por sus costumbres y modo de vida, quien con serenidad y absoluta moderación razonablemente gobernaba tanto los asuntos atañederos a la iglesia como el propio redil de Cristo, de modo tal que a causa de ésa su afortunada mesura el obispo descansaba en él para cualquier acto administrativo 
relacionado con la iglesia o con la totalidad del pueblo. Por lo que todos, desde el más grande hasta el más pequeño, dábanle gracias y lo amaban. Pues a los huérfanos, a los desnudos y a los indigentes con pertinencia suministraba lo adecuado.

(2) Ocurrió entonces que, habiéndolo llamado Dios, el obispo de dicha ciudad llegó al fin de su vida, e inmediatamente todos los eclesiásticos y el pueblo entero, profesando afecto al vicario y reconociendo su diligencia, de común acuerdo decretaron que fuera hecho obispo y dirigieron sin demora el solemne decreto al obispo metropolitano. Éste, recibido aquély reconocidas las virtudes del varón designado, asintió a lo decidido por los solicitantes y ordenó compareciese el vicario. Éste, sin embargo, tras de recibida la carta del obispo metropolitano, de inmediato rehusó a viajar, rogando a todos que no lo compelieran a ser hecho obispo sino que les bastara con que fuese vicario, y afirmando y declarando solemnemente no ser merecedor de un cargo de tan gran honra. No obstante, como el pueblo lo apremiara, tomado por debajo del brazo fue conducido hasta el obispo metropolitano y recibido con gozo. La consagración era inminente. Pero él entonces, postrado en el suelo, abrazando los pies del obispo suplicaba que nada de eso se ejecutase en él, proclamándose completamente inmerecedor del rango episcopal y consciente sin reservas de sus propios pecados. Y luego de que durante mucho tiempo estuvo inmóvil en el suelo y humillado así a los pies del obispo, se le concedió un lapso de tres días para que reflexionara. Ahora bien, después del tercer día, llamándolo ante sí el obispo comenzó a exhortarlo y a elogiar su pericia. Pero él se declaraba indigno de ascender los peldaños de sitial tan eminente. Por lo cual, viendo tal persistencia suya en la obstinación y que de ninguna manera quería dar su consentimiento, el obispo lo despidió y promovió a otro hombre, digno, para que ejerciera el cargo episcopal de aquella iglesia.

(3) Más tarde, consagrado ya el obispo y cuando hubieron retornado a su propia ciudad, algunos clérigos lo incitaron a que, removiendo al anterior, nombrase vicario a otro miembro de la iglesia. Hecho lo cual, el que había sido separado de su cargo precedente sólo se ocupaba de la atención de su casa. Ahora bien, el astuto adversario y envidioso enemigo del género humano, al ver a ese varón vivir modestamente y dedicarse a ejecutar buenas acciones, comenzó a hacer latir su corazón con pensamientos depravados, haciendo entrar en él los celos por el vicariato y la 


\section{LUIS ASTEY}

envidia de la ambición, y lo encaminó hacia esas abominables e inicuas deliberaciones con la que no la divina sino la humana gloria deseara y, más que la celeste, apeteciera una transitoria dignidad, todo ello a grado tal que demandase los auxilios de los hechiceros.

(4) Residía por entonces en la misma ciudad cierto nefandísimo hebreo, operador de todo tipo de artes diabólicas, quien, con sus artificios para hacer negar la fe, a muchos había ya sumergido en el foso infernal de la perdición. En tanto, encendido de inane gloria, el infelicísimo vicario había caído en revolver dentro de sí, confusa y obstinadamente, la avidez por este mundo, y ardía con el deseo de la ambición. Por lo cual con rapidez acudió de noche al susodicho hebreo y, llamando a su puerta, solicitaba acceso. En consecuencia, viéndolo abatido así, aquel hebreo odioso a Dios lo invitó al interior de la casa y le dijo: " $\measuredangle A$ causa de qué has venido a mí?" Y él, cayẹndo humillado ante sus pies, decía: "Te lo ruego, ayúdame, porque mi obispo ha ejercido injuria contra mí y me ha llevado a la ruina con eso." Le respondió el execrable hebreo: "Mañana por la noche, a esta hora, ven a mí, y te conduciré a mi señor y él te ayudará en lo que quieras." Aquél entonces, oyendo esto con alegría, actuó así y a media noche vino a él. El nefando hebreo, por su parte, lo condujo al circo de la ciudad y le dijo: "De cualquier cosa que vieres u oyeres no te horrorices, y no hagas para ti el signo de la cruz."

12 Habiéndolo prometido él solemnemente, de pronto le mostró unos entes vestidos de blanco, con una multitud de candelabros y dando grandes gritos, y su príncipe sentado en medio de ellos: eran en verdad el Diablo y sus ministros. Ahora bien, sujetando el desdichado judío la mano del vicario, lo condujo a la infame asamblea. Y el Diablo le dijo: "¿Por qué has traído hasta nosotros a este hombre?" Respondió: "Juzgado sin justicia por su obispo, y habiéndome solicitado vuestra ayuda, señor mío, lo he traído." Dijo entonces aquél: "¿Qué clase de ayuda he de prestar a un hombre que sirve a su Dios? Más si desea ser mi siervo y ser contado entre nuestros militantes, lo auxiliaré de tal modo que pueda hacer más que anteriormente e imperar sobre todos, el obispo inclusive." Vuelto hacia él, dijo el hebreo al infeliz vicario: "¿Oíste lo que te dijo?" Él respondió: "Lo he oído, y cualquier cosa que me pida la haré en tanto que me auxilie." Y comenzó a besar los pies del príncipe y a rogarle. Dijo el Diablo al hebreo: "Que niegue al hijo de María y a clla misma, porque me son odiosos, y que ponga por escrito que los niega absolutamente, y 


\section{LA LEYENDA DE TEÓFILO}

cualquier cosa que quisiere la obtendrá en tanto que los siga negando." Entonces Satanás se introdujo en el vicario y éste dijo: "Niego a Cristo y a su madre." Y haciendo un pacto autógrafo puso cera en él y lo selló con su propio anillo, y se retiraron ambos con gran gozo por su perdición.

(5) Ahora bien, al día siguiente, con todo honor vuelto a llamar de su retiro el vicario, el obispo - movido, pienso, por la Divina Providencia-, expulsado vergonzosamente aquél a quien él mismo promoviera, otra vez instituyó al primero como vicario y delante de todo el clero y del pueblo le confirió autoridad para la administración de la santa iglesia y sobre las posesiones que le correspondían así como sobre la multitud entera. Y fue privilegiado doblemente de cuanto lo fuese antes y de nuevo sublimado en honor, a grado tal que el obispo en voz alta declaró que había pecado al rebajar a tan idónea y perfecta persona y promover a un inútil y menos idóneo. Nuevamente provisto de poder, comenzó a dar órdenes y a enaltecerse por encima de todos el propio vicario, obedeciéndolo todos con miedo y temblor y sirviéndolo durante poco tiempo. Mas con frecuencia el execrable hebreo se dirigía ocultamente al vicario y le decía: "¿Has visto de qué modo de mí y de mi señor obtuviste beneficio y rápido remedio en lo que impetraste?" Y él: "Lo confieso y en verdad doy gracias por tu cooperación."

\section{Capítulo II}

Arrepentimiento de Teófilo.

Esperanza de perdón obtenida

de la virgen madre de Dios.

(6) Y cuando hubo permanecido breve tiempo en tal jactancia y en el foso profundo de su negación, el creador de todo y redentor nuestro, Dios, quien no quiere la muerte de los pecadores sino su conversión y vida, recordando su anterior manera de vivir y el modo como administrar la santa iglesia de Dios y que a las viudas, a los huérfanos y a los indigentes abasteciera óptimamente, no despreció a su creatura sino le dio la conversión del arrepentimiento. Y vuelto en sí de arrogancia y negación tan grandes, recuperada la mesura comenzó a hacer humildes sus propios 


\section{LUIS ASTEY}

pensamientos y a afligirse por los actos que había ejecutado, dedicándose a los ayunos y oraciones y noches de vela y revisando muchas cosas en su mente. Y considerándose privado de la salvación, atormentado, meditando en el suplicio del eterno incendio y en la muerte eterna del alma, en el fuego inextinguible, en el crujir de dientes y en el gusano que no muere, con temor poniendo ante sí mismo todas esas cosas, aterrado y con gemido y amargas lágrimas dijo: "Oh, miserable de mí, ¿qué hice y qué he realizado? ¿A dónde me dirigiré ahora, colmado de suntuosidad, para hacer salvar mi alma? ¿A dónde iré yo, infeliz pecador, que negué a mi Cristo y a su santa madre y me hice siervo del Diablo mediante la nefanda garantía de un pacto autógrafo? ¿Qué hombre piensas que lo pueda sustraer de la mano del Diablo devastador y, así, ayudarme? ¿Qué necesidad tuve de conocer a ese nefando e incinerable hebreo? ..." (En verdad, poco tiempo antes el hebreo había sido condenado por la ley y por el juez) “...¿Qué, entonces? Así son recompensados quienes, abandonando al Dios y señor, acuden al Diablo. ¿De qué me aprovechan lo temporalmente ventajoso y la altivez de este vano mundo? Ay de mí, miserable y presuntuoso pecador, ¿de qué modo he sido atrapado? Ay de mí, miserable pecador, ¿de qué modo he perdido la luz e ingresado a las tinieblas? Me hallaba bien mientras fui apartado de la administración; ¿por qué deseé, a causa de una gloria vana y una vacua reputación,

14 entregar mi alma miserable a la gehena? ¿Qué auxilio pediré, yo que de cualquier auxilio he sido defraudado por el Diablo? Yo soy el culpable de este asunto, yo soy el autor de la perdición de mi alma, yo soy quien he traicionado mi propia salvación. Ay de mí, ignoro de qué manera he sido arrebatado de mí mismo. Ay de mí, iqué haré; a quién iré; qué responderé en el día del juicio, cuando todas las cosas aparecerán abiertas y desnudas? ¿Qué diré en aquella hora en que los justos serán coronados y, en cambio, seré condenado yo? ¿O con qué seguridad compareceré ante el tribunal regio y terrible? ¿A quién rogaré, a quién imploraré en esa tribulación? ¿O a quién llamaré en aquella necesidad, cuando todos estarán ocupados de lo suyo y no de lo de otros? ¿Quién tendrá misericordia de mí? ¿Quién vendrá en mi socorro, quién me protegerá, quien me dará su patrocinio? Nadie, ciertamente; ahí nadie ayuda sino todos dan cuenta de sí mismos. iAy, miserable alma mía, de qué manera fuiste aprisionada, de qué manera has sido deshecha, de qué manera has sido engañada y demolida, en qué clase de ruina te has 


\section{LA LEYENDA DE TEÓFILO}

derrumbado, en qué naufragio te has sumergido, por qué lodo has sido envuelta! ¿En qué puerto te refugiarás ahora? ¿A qué remedio has de acudir? iAy de mí, miserable, que, atrapado y sumergido en el abismo, no me puedo levantar!

(7) Y mientras durante largo tiempo dentro de sí debatía con su alma estas cosas y tales simientes de salvación eterna estaban siendo sembradas en su ánimo, Dios, único misericordioso y compasivo, que no desprecia a su creatura sino la sostiene, lo cercó con otro pensamiento. Dijo el vicario: "Aun cuando sé que al Hijo de Dios, nacido de la santa e inmaculada siempre virgen madre María, señor nuestro Jesucristo, y a ella, los he negado por mediación de aquel hebreo que conocí en mala hora, iré, no obstante, a esa misma santa y gloriosa, resplandeciente madre de Dios, a ella sola recurriré con toda mi alma y corazón y haré sin cesar oraciones y ayunos en su venerable templo, hasta que mediante ella encuentre misericordia para el día del juicio." Y a continuación decía: "Pero ignoro con qué labios intentaré impetrar su benignidad, pues sé ciertamente que he pecado contra ella. ¿Y con qué preámbulo iniciaré mi confesión? ¿Confiando en qué estado de mi corazón y en qué condición de mi conciencia intentaré mover mi lengua impía y mis mancillados labios? ¿Y por cuáles pecados, miserable yo, en primer término buscaré remisión? Que si osare hacer esto con imprudencia, un fuego descendido del cielo me consumirá, porque ya no soporta el mundo los males que yo, miserabilísimo, he obrado. Ay, miserable alma, levántate de las tinieblas que te han envuelto, invoca, prosternándote, a la madre de nuestro señor Jesucristo, porque verdaderamente ella tiene potestad para imponer a esta culpa una penitencia saludable."

(8) Y pensando esto dentro de sí, vigorosamente animado y dejados los abrumadores tropiezos de este mundo, con toda diligencia y resuelta voluntad delante de todos se prosternó en el santo y venerable templo de la inmaculada y gloriosa siempre virgen María, de día y de noche, presentándole sin cesar peticiones y plegarias y pasando el tiempo en ayunos y noches de vela con el fin de, retirado ya de tantos crímenes, ser redimido de ellos y liberado del pernicioso engañador y dragón maligno así como de la negación que había hecho, practicando durante cuarenta días con sus noches ayunos y oraciones en solicitud de perdón a nuestra protectora, la madre del Señor salvador nuestro. 


\section{LUIS ASTEY}

(9) Y, en verdad, después del cumplimiento de esos días, en medio de la noche claramente apareció el universal auxilio y dispuesta protección de los cristianos que están atentos a ella, verdadero refugio de quienes a ella se acogen, senda de los extraviados y redención de los cautivos, verdadera luz para quienes minan en las tinieblas, refugio de los afligidos y consuelo de los atribulados, la señora nuestra y verdadera madre de Dios, diciéndole: "¿Por qué así, hombre, sin razón y fastidiosamente persistes en suplicar que te ayude, hombre que has negado a mi Hijo, salvador del mundo, y a mí? ¿O de qué modo puedo proponer a Él que te perdone las malas acciones que has cometido? ¿Con qué ojos miraré al rostro a ese misericordiosísimo Hijo mío, a quien tú has negado, y me atreveré a rogarle por ti? ¿Con qué confianza puedo suplicarle cuando tú has apostatado de Él? ¿O de qué manera me presentaré ante el terrible tribunal y osaré abrir mi boca y solicitar su benevolencia clementísima? $Y$, en verdad, no soporto ver que mi Hijo sea denigrado injuriosamente. Concedo, hombre, que los pecados que cometiste contra mí puedan encontrar cierta indulgencia por cuanto que amo piadosamente a la estirpe de los cristianos y más aún a aquellos que con recta fe y conciencia limpia acuden a mi templo. A éstos de todas las maneras posibles los acepto y los ayudo y los estrecho entre mis brazos y los abrigo entrañablemente. Mas no soporto ni oír ni ver a quienes vilipendian a mi Hijo,

16 porque necesitan de muchos combates y trabajos y arrepentimientos de corazón para poder alcanzar su benignidad. Pues en verdad es misericordioso, pero extremadamente justo y santo juez."

(10) Ahora bien, el varón, respondiéndole, le dijo: "Sí, Señora mía siempre bendita, sí, Señora que eres protección del género humano, sí, Señora que eres puerto y sostén de quienes se refugian en ti, sé, Señora, sé que mucho he pecado contra ti y contra Aquél que nació de ti, nuestro Señor, y que no soy digno de obtener misericordia. Pero tomo ejemplo de quienes anteriormente pecaron contra tu Hijo, señor nuestro, y mediante arrepentimiento merecieron el perdón de sus pecados, y por eso me atrevo a acercarme a ti. En verdad, si no fue por el arrepentimiento, ¿cómo los ninivitas fueron salvados? De no ser por el arrepentimiento, Rahab, la prostituta, no hubiese alcanzado salvación. Si no fue por el arrepentimiento, icómo David, habiendo caído en el abismo de la fornicación y del homicidio tras de obtener el don de la profecía y de recibir el testimonio del Señor y el reino, al manifestar su arrepentimiento con 


\section{LA LEYENDA DE TEÓFILO}

su palabra mereció no sólo el perdón de sus grandes pecados sino asimismo de nuevo el don de la profecía? Si no fue por el arrepentimiento, ¿cómo el bienaventurado Pedro, príncipe de los apóstoles, primero entre los discípulos, columna de la Iglesia, quien recibió de Dios las llaves del reino de los cielos, habiendo negado al señor Cristo no una ni dos sino tres veces, llorando amargamente después de ello obtuvo el perdón de tan graves pecados y, adquiriendo más grande honor, fue hecho pastor del divino y racional aprisco? Si no fue por el arrepentimiento, ¿cómo Él acogió a Zaqueo, preeminente entre los publicanos y los calumniadores? Si no fue por el arrepentimiento, ¿cómo el bienaventurado Pablo se convirtió de perseguidor en vaso de elección? Si no fue por el arrepentimiento, ¿cómo este apóstol hubiera ordenado perdonar a aquel corintio que fornicó, diciendo: 'No sea que lo atrape Satanás'? Si no fue por el arrepentimiento, ¿cómo aquél que tantas maldades cometía, Cipriano, quien en verdad hendía a las preñadas y se implicaba en ignominias de toda clase, con vigor fortalecido por santa Justina, acogiéndose al arrepentimiento no sólo recibió la remisión de tantas perversidades sino también fue agraciado con la palma del martirio? Por lo que asimismo yo, pecador, confiado en el indicio de tantos, me acerco, suplicando a tu benigna misericordia, para que me tiendas tu protectora mano derecha y te dignes concederme el perdón de mis pecados. Por tu hijo, el señor nuestro Jesucristo, contra quien yo, miserable, pequé."

(11) Y cuando de este modo él declaraba, la santa y venerable señora nuestra, madre de Dios, única casta, única santa en alma y en cuerpo, única en tener facultad para hablar delante de Aquél a quien ella engendró, delante de Cristo, consolación de los atribulados, compasión para los afligidos, vestimenta para los desnudos, báculo de la ancianidad, sólida protección de quienes acuden a ella, quien con sus santas entrañas da calor a todos los cristianos, le dijo: "Confiesa ante mí, hombre, que aquél Hijo a quien yo di a luz y negaste tú es el Cristo, hijo del Dios viviente, que ha venido a juzgar a los vivos y a los muertos, y yo rogaré por ti y te apoyaré." Y respondió el vicario: "¿Y cómo me atreveré, Señora mía siempre bendita, yo, infeliz e indigno y que tengo la boca mancillada y sucia, que negué a tu Hijo, señor nuestro, y que he sido atrapado por los vanos deseos de este mundo? Y no eso únicamente, sino que lo que tenía para remedio de mi alma, quiero decir la venerable cruz y el santo bautismo que recibí, lo manché mediante el acta de amarguí- 


\section{LUIS ASTEY}

sima negación que he firmado." Y le dijo la santa e inmaculada madre de Dios siempre virgen María: "Tú solamente acércate a Él y confiésalo, porque Él es misericordioso y aceptará las lágrimas de tu arrepentimiento y del de aquellos que limpia y sinceramente se acerquen a Él. En verdad a causa de eso Él, siendo Dios, se dignó tomar carne de mí, sin mengua de su deidad; para hacer salvo al género humano."

(12) Entonces el bienaventurado varón, con reverencia y palabra adecuadas, inclinado el rostro y gimiendo confesó: "Creo en el señor nuestro Jesucristo y lo adoro y enaltezco, persona de la Santa Trinidad, hijo del viviente Dios, inefablemente nacido del Padre antes de los siglos y, verdadero Dios, en tiempos muy recientes descendido del cielo y por el Espíritu Santo encarnado en ti, santa e inmaculada virgen María, y que vino al mundo para salvación del género humano. Confieso que Él es el verdadero Dios y verdadero hombre que a causa de nosotros pecadores se dignó sufrir y ser escupido y abofeteado y extendió los brazos sobre el madero vivificante, entregando su vida, como buen pastor, por nosotros pecadores. Y que fue sepultado y resucitó y ascendió al cielo en la carne que recibió de ti, Castísima, y en su santa gloria ha de venir a juzgar a los vivos y a los muertos, sin necesidad de acusador sino acusándonos o excusándonos nuestra conciencia de las mismas obras que serán juzgadas, y poniendo el fuego a prueba cuál haya sido la obra de cada uno. Estas realidades las confieso con mi alma, mi cuerpo y mi corazón, las profeso, les doy culto y las adoro. Y con esta mi impetratoria garantía, dada con todo el esfuerzo de mi mente, preséntame, santa e inmaculada virgen madre de Dios, ante tu Hijo el señor nuestro, y no rechaces ni desprecies mi plegaria por haber sido arrebatado, abatido y atrapado, sino librame de las iniquidades que me aprisionan y de la tempestuosa turbulencia que me posee, pues me hallo despojado de la gracia del Espíritu Santo." Y cuando hubo dicho esto, la santa madre de Dios, esperanza y sostén de los cristianos, redención de los extraviados y senda verdadera de quienes a ella acuden, manantial para los indecisos, la que intercede por los pecadores, alivio de los pobres y mediadora entre los hombres y Dios, admitiendo eso como suficiente disculpa de él, le dijo: "He aquí que yo, creyéndote a causa del bautismo que recibiste mediante mi hijo Jesucristo y a causa de la excesiva compasión que hacia vosotros los cristianos tengo, me acercaré a Él y arrojada a sus pies le rogaré por ti, en la medida en que él te acepte." 


\title{
LA LEYENDA DE TEÓFILO
}

\author{
Capítulo III \\ Los pecados perdonados. \\ Devuelto el pacto autógrafo. \\ Muerte de Teófilo.
}

(13) Y cuando esta visión se hubo mostrado y la mañana se hubo hecho, se retiró de él la inmaculada virgen madre de Dios. Y durante tres días más el vicario, orando y golpeando con fuerza su rostro contra el piso, permaneciendo sin alimento en el mismo venerable templo y regando con lágrimas el sitio, no se retiraba de él y dirigía continuamente la mirada hacia la clara luz e inefable rostro de la gloriosa madre de Dios, aguardando de ella esperanza de salvación. por lo que una vez más la única protección, el consuelo único de quienes a ella acuden, la única blanca oblea glorificante, la que fue nutrida en el santo de los santos, apareció ante él con risueño rostro y ojos de alegría, diciéndole con sosegada voz: "Hombre de Dios, es suficiente tu arrepentimiento, el que has mostrado ante el Dios creador y el Salvador de todo. Acepta el Señor tus lágrimas y asiente a tus peticiones a causa de mí, siempre y cuando hacia Cristo, hijo del viviente Dios, observes todo eso en tu corazón hasta el día de tu muerte." Y respondió él: "Sí, Señora mía, acataré y no dejaré de lado tus palabras porque a ti tengo, después de Dios, por protección y patrocinio, $\mathrm{y}$, confiando en tu ayuda, no desatenderé lo que prometí y he confesado. Sé, en verdad, sé que no hay para los hombres otra protección sino solamente tú, siempre bendita. Pues, ¿quién, inmaculada virgen Señora mía, ha esperado en ti y ha sido confundido? ¿O qué hombre ha pedido la omnipotencia de tu ayuda y ha sido abandonado? Por lo que ruego también yo, pecador y presuntuoso, a la perenne fuente de tu benignidad extender sobre mí, errado y engañado, las entrañas de tu misericordia, pues me hallo sumergido en el cieno. Ordena por ello que pueda recuperar la execrable acta de negación y nefanda garantía firmada para aquél que me engañó, el Diablo, porque esto es lo que intensamente hace temblar a mi misérrima alma."

(14) Así pues, de nuevo lamentándose mucho y derramando copiosas lágrimas, el antedicho varón, requiriendo a la esperanza única de todos y salvación de las almas nuestras, oraba a la santa y siempre virgen María. 


\section{LUIS ASTEY}

Y luego de tres días más, como si fuera en una visión ella le presentó el acta de garantía, provista del sello de cera, tal como lo otorgó él —esto es, la garantía apostática. Y al levantarse del sueño encontró el acta sobre su pecho el ya mencionado vicario y, lleno de álegría por lo sucedido, comenzó a temblar de tal modo que las articulaciones de todos sus miembros se distendieron.

(15) En verdad al día siguiente, como fuese día del Señor, habiendo entrado en la santa católica iglesia, después de la lectura del santo Evangelio se lanzó a los pies del santísimo obispo y minuciosamente todo lo relató: lo que fue realizado por execrable y pernicioso hechicero hebreo, en su propia arrogancia y negación, la redacción del pacto autógrafo motivada por la inane gloria de este mundo, en seguida su confesión a Dios y al señor nuestro Jesucristo y su arrepentimiento mediante milagros, y luego el indefectible manantial de la inmaculada madre de Dios, por quien recibió en devolución el autógrafo pacto de pésima negación. Y tendiendo al santísimo obispo el documento sellado, lo entregó en sus manos, y simultáneamente se asombraron todos, clérigos y laicos, mujeres y niños. $\mathrm{Y}$ él pidió que con toda claridad y delante de todos fuera leído el muy inicuo y espantoso pacto autógrafo. Y el pueblo entero supo lo que le había ocurrido y de qué modo le había sido devuelta el acta de negación.

20 (16) Por lo que también el obispo clamó y dijo: "Venid, todos los fieles, glorifiquemos a Jesucristo, nuestro verdadero señor. Venid todos, mirad estos pasmnsos milagros. Venid, amados de Cristo, y mirad a quien no quiere la muerte del pecador sino su conversión y vida eterna. Venid, padres míos, mirad la eficacia del arrepentimiento. Venid, mirad las lágrimas que lavan los pecauos. Venid, queridísimos, mirad las lágrimas que borran las cicatrices de las acciones inicuas y hacen ver el alma más blanca que la nieve. Venid, mirad las lágrimas que vuelan llevando al alma hacia el Señor. Venid, mirad las lágrimas que obtienen la remisión de los pecados. Venid, cristianos todos, contemplad las lágrimas que extinguen la cólera de Dios. Venid, observad cuán eficaces son los gemidos del alma y la contricción de los corazones. ¿Quién no quedará admirado, hermanos, de la inefable tolerancia de Dios? ¿Quién no quedará estupefacto de la inenarrable compasión y caridad de Dios hacia nosotros pecadores? Durante cuarenta días ayunó el legislador Moisés, y recibió las tablas escritas por Aquél: este hermano nuestro permaneció 
en ayuno durante cuarenta días en el venerable templo de la gloriosa virgen María, y volvió a recibir la anterior gracia que por negar perdiera. Por lo tanto, al mismo tiempo que él también nosotros demos gloria al Dios nuestro, que tan misericordiosamente respondió al arrepentimiento de quien en Él buscó refugio por intervención de la inmaculada siempre virgen María, la que entre los hombres y Dios es puente, verdadera esperanza de los desesperados y refugio de los afligidos, la que atempera la maldición de la naturaleza humana, la que es verdadera puerta a que todos los pecadores llamamos y se abre, y la que a Aquél a quien ella engendró, al Señor nuestro, lleva nuestras peticiones y recibe de Él el perdón de nuestros pecados. Acuérdate por tanto asimismo de nosotros, santa madre de Dios, que estamos atentos a ti y en ti nos refugiamos, y no abandones desválido al aprisco sino suplica por él a Dios misericordioso e intercede para que sea conservado en prosperidad y sin oprobio. Pues todos los cristianos esperamos en ti y a ti acudimos y hacia ti de día y de noche levantamos nuestros ojos, y a ti verdaderamente y a quien tomó carne de ti, el señor nuestro Jesucristo, rendimos honor y glorificamos. ¿Y qué más diré o hablaré, o qué clase de alabanza o gloria ofreceremos a nuestro señor Dios omnipotente Jesucristo, quien de ti nació? Ciertamente, Señor, excelsas son tus obras y no hay lengua que baste para expresar la grandeza de tus milagros. Excelsas verdaderamente son tus obras, y de hecho adecuada esta sentencia del Evangelio: 'Traed la mejor ropa y ponédsela, dadle un anillo para su mano y calzado para sus pies y traed un ternero cebado y matadlo, y alegrémonos mientras comemos, porque este hermano nuestro estaba muerto y ha resucitado, había desaparecido y fue hallado."”

(17) Y después de que el vicario se hubo levantado, el obispo le pidió quemar la nefandísima acta, lo que fue hecho. Y el pueblo, al ver consumido por el fuego el execrable pacto autógrafo y denegatoria garantía, se puso a clamar durante largo tiempo y entre muchísimas lágrimas: "Kyrie eleison". Y haciendo con la mano una señal para que callasen, dijo el obispo: "Paz a vosotros", y procedió a celebrar los ritos de la misa. Y tras el cumplimiento de los sagrados misterios y la recepción del alimento sacro, al punto refulgió como el sol el rostro del vicario venerable, $y$, viendo la súbita transfiguración del varón, todos glorificaban grandemente a Dios, único que hace milagros tan magníficos. 


\section{LUIS ASTEY}

(18) Y después de regresar al venerable templo de la madre de Dios, la que lo liberó de su error execrable, y de comer parcamente, decaído de cuerpo desfalleció en el mismo lugar en donde se halla sepultado y en donde asimismo contempló aquella feliz visión, quedando como clavado en ese sitio. Y luego de tres días, tras de dar el ósculo a los hermanos, de distribuir lo suyo entre los indigentes y disponer así óptimamente de ello y de haber glorificado a Dios con su confesión, puso su alma bienaventurada en las manos del Hijo de Dios y de la inmaculada siempre virgen María y se encaminó hacia el Señor, de quien es la gloria hoy y siempre por los siglos de los siglos. Amén.

3d. Expuesta ya la leyenda, aun cuando sea en traducción de traducción, tal vez procedería tanto contextualizarla como examinar los elementos que la constituyen: tiempos, ambientes, personajes, acciones, parlamentos, ideas, estilo, etcétera, y, como resultado de ambas operaciones, poner de manifiesto su significado cultural ë ideológico o, cuando menos, algunos aspectos de él —así por ejemplo las implicaciones de la problemática del poder en los estratos divino, humano y diabólico o el sentido de la estereotipada representación del judío como ente maligno, cristiana y medieval, desde luego, aunque por desgracia no exclusivamente. Otra conocida y sabia sentencia, ahora de Horacio: "Sé breve" (Epístola a los Pisones, v. 335), hasta el momento no muy bien observada

22 en este discurso, con toda sensatez advierte que sería impropio desarrollar esa temática en la actual ocasión.

4. Pero queda un tópico más, en el que lo emotivo de nuevo predomina: hacer constar el debido agradecimiento a la Academia Mexicana, no en cuanto corporación abstracta sino como conjunto de las distinguidas personas que actualmente la integran, por la designación con que me ha favorecido, y en particular a Don Manuel Alcalá Anaya, a Don José G. Moreno de Alba y a Don Roberto Moreno de los Arcos, quienes propusieron que eso así fuese. $\mathrm{Y}$, por otra parte, agradecer también a todos los presentes el haber escuchado estas palabras. 
LA LEYENDA DE TEÓFILO

\section{COMPLEMENTO BIBLIOGRÁFICO}

\section{Leyenda de Teófilo}

\section{A. Textos griegos:}

L. Radermacher (ed.), "Theophilus", en Griechischen Quellen zur Faustsage (Viena y Leipzig, 1927; Sitzungsberichte der Akademie der Wissenschaften in Wien: Philologisch-historische Klasse, 206-4), 151219. Versión de Eutiquiano: p. 182-218.

B. Traducción de Paulus:

J. Bollandus y G. Henschenius (eds.), "Miraculum S. Marie de Theophilo penitente auctore Eutychiano, intérprete Paulo Diacono Neapoleos", en Acta Sanctorum Frebruarius (1658, Amberes,), 483-9.

C. Algunas reelaboraciones:

1. Hrotsvithae opera, ed. K. Strecker (1930, 2a., Leipzig, Bibliotheca Scriptorum Graecorum et Romanorum Teubneriana, 1850), 67-80.

2. Santiago de la Vorágine, La leyenda dorada II, trad. J.M. Macías (1984, 2a., Madrid,), 850-861. Leyenda de Teófilo: p. 854.

3. Rutebeuf, Le miracle de Théophile, Ed. G. Frank, 1949, 2a., París, Les Classiques Francais du Moyen Age, 49.

4. Gonzalo de Berceo, Los milagros de Nuestra Señora, ed. B. Dutton (1971, Londres; Obras completas, II), 211-47.

5. Castigos é documentos del rey Don Sancho, ed. P. de Gayangos, en Escritores en prosa anteriores al siglo XV (1860, Madrid; Biblioteca de Autores Españoles, 51), 214-7. 'Enjienplo': p. 215.

6. C. Sánchez de Vercial, Libro de los exenplos por A.B.C., ed. J.E. Keller (1961, Madrid: Consejo Superior de Investigaciones Científicas, Clásicos Hispánicos, II v), 201-2.

7. Alfonso X, Cantigas de Santa María I, ed. W. Mettman (1959, Coimbra; Acta Universitatis Conimbrigensis), 9-10. 


\section{LUIS ASTEY}

\section{II: Leyenda de Fausto}

A. Precedentes y estudios

1. Th. Zahn, Cyprian von Antiochen und die deutsche Faustsage, 1882, Erlangen.

2. R. Petsch, Theophilus: mittelniederdeutsches Drama in drei Fassungen, 1908, Heidelberg, Germanische Bibliothek, II 2.

3. C.Plenzat, Die Theophiluslegende in den Dichtungen des Mittelalters, 1926, Berlín, Germanische Studien.

4. L. Radermacher, op. cit.

5. Ph. M. Palmer y R.P. More, The sources of the Faust tradition: from Simon Magus to Lessing, 1936, Nueva York.

B. Textos modernos

1a. Historia von D. Johann Faustus, dem weitbeschreyten Zauberer und Schwarkkünstler, 1587, Frankfurt.

1b. El libro popular del doctor Fausto, Trad. M. Oeste de Bopp, Revisión: O. Zorrilla y C. Tercero, 1984, México.

2a. Ch. Marlowe, Works, ed. C.F.T. Brooke (1957, Oxford), 139-229.

2b. Id., La trágica historia del doctor Fausto, Trad. M. Cohen, 1983,

24 Barcelona, Icaria Literaria, 21.

3a. J.W. von Goethe, Faust: eine Tragödie, 1947, Berlín.

3b. Id., Fausto, Trad. J. Roviralta B.; ed. M.J. González y M.A. Vega, 1987, Madrid, Cátedra: Letras Universales, 77.

\section{El mágico prodigioso}

1. Texto: P. Calderón de la Barca, El mágico prodigioso, Ed. B.W. Wardropper, 1988, México, Rei: Letras Hispánicas, 217.

2. Estudio: Ch. Dédéyan, "Un sujet parallèle: El mágico prodigioso", en Le thème de Faust dans la littérature européenne II (1954, París), 145-226. 
RESPUESTA

\title{
RESPUESTA AL DISCURSO DE INGRESO DE DON LUIS ASTEY A LA ACADEMIA MEXICANA DE LA LENGUA
}

\author{
Mtro. Manuel Alcalá*
}

\section{I}

Honró durante treinta y cinco años la silla número XXXVI Monseñor Octaviano Valdés. Humanista y gran conocedor de la literatura latina, cultivó también la poesía y la novela. De ello se han percatado ustedes por la memoria que de él ha traído para nosotros don Luis Astey. Su primera formación fue la del jurista. Obtuvo, en efecto, su licenciatura en Derecho y Ciencias Sociales en la Universidad Autónoma de Guadalajara, con título de la Universidad Nacional Autónoma de México. Su formación de jurista la corona con su vocación de humanista. Pero no exclusivamente en el campo de la literatura clásica latina, como su predecesor. Su terreno es otro y muy amplio.

Con una beca de la Alianza Francesa de México hizo estudios sobre literaturas antiguas del Cercano Oriente y sobre el drama latino medieval. Ello fue en la Facultad de Letras de la Universidad de París - Sorbona-y en la École Pratique des Hautes Études.

Su interés por el antiguo mundo del Cercano Oriente lo llevó a Madrid con una beca del Instituto de Cultura Hispánica. En la Villa del Oso y el Madroño hizo una investigación dirigida sobre antigua literatura mesopotámica. Ello fue en el Instituto Benito Arias Montano del Consejo Superior de Investigaciones Científicas.

En la Harvard Graduate School, con beca de la Fundación Rockefeller, hizo una investigación dirigida sobre literatura clásica griega.

* Miembro de la Academia Mexicana correspondiente de la Española. 


\section{MANUEL ALCALÁ}

Esa amplia y sólida preparación da sus frutos en la docencia, en la investigación y en diversas publicaciones. También las bibliotecas le deben mucho.

\section{II}

A sus veinticuatro años empieza su consagración a la docencia como profesor de tiempo completo en el Departamento de Humanidades del Instituto Tecnológico y de Estudios Superiores de Monterrey de septiembre de 1945 a julio de 1973. En esos mismos años fue profesor de Literatura Griega Clásica en la Facultad de Filosofía y Letras de la Universidad de Nuevo León. Pero en ella empezó su enseñanza en septiembre de 1951.

Desde mediados de 1973 lo tenemos en la ciudad de México dedicado siempre a la docencia en tres instituciones: la Facultad de Filosofía y Letras de la Universidad Nacional Autónoma de México, el Departamento de Estudios Generales del Instituto Tecnológico Autónomo de México y El Colegio de México.

En la primera fue profesor de asignatura (Literatura medieval) de septiembre de 1973 a julio de 1988, en la Licenciatura de Letras Hispánicas. Y desde septiembre de 1981 lo es en la División de Estudios de Posgrado. En el segundo se desempeña como profesor de tiempo completo y ha dado cursos de Historia de las Ideas. En el Centro de Estudios Lingǘ́sticos y Literarios de El Colegio de México profesa diversos cursos, principalmente de Literatura Medieval.

\section{III}

Por lo que atañe a la investigación, lo vemos en El Colegio de México desde septiembre de 1977 como Investigador de proyecto en el Centro de Estudios Lingüísticos y Literarios. Desde julio de 1988 en el mencionado Instituto Tecnológico Autónomo de México tiene derecho a dedicar a la investigación el sesenta por ciento del tiempo. Desde esa misma fecha hasta junio de 1991 estuvo en el Sistema Nacional de Investigadores, en el nivel II. Pasó al nivel III en julio de 1991 y sigue en él. Los temas de investigación son en Literatura y en Filología. 


\section{RESPUESTA}

Por lo que a bibliotecas de refiere, fue Director de la Biblioteca del Instituto Tecnológico y de Estudios Superiores de Monterrey de enero de 1961 a agosto de 1973.

También está empeñado en otras actividades.

Desde 1984 es Coordinador de la "Biblioteca Novohispana" en el Centro de Estudios Lingüísticos y Literarios de El Colegio de México. Es Miembro del Consejo de Redacción de la Nueva Revista de Filología de dicho Colegio, y también forma parte del Consejo Editorial de la Revista Estudios, publicada por el Departamento de Estudios Generales del Instituto Tecnológico Autónomo de México.

\section{IV}

Por lo que a sus publicaciones concierne, ellas son o bien originales, o bien traducciones directamente de textos mesopotámicos, griegos o latinos, o ya ediciones de temas medievales, todas ellas acompañadas de notas e introducciones.

De sus publicaciones originales, señalo Procedimientos de edición para la "Biblioteca Novohispana" que publicó El Colegio de México en 1985.

Por su interés en los temas mesopotámicos y del Cercano Oriente, señalo las cuatro siguientes: El poema de la creación "Enuma elish" que se publicó en Monterrey en 1961 al cobijo de Arte A.C. y de la Asociación de Estudiantes de Arquitectura del Instituto de Estudios Superiores de Monterrey. Ese mismo año y en Monterrey también la revista Humanitas publica, en sus páginas 299 a 323, "El mito acadio de Zu y dos documentos afines". Siempre en Humanitas de Monterrey —páginas 237 a 256-, "Algunos textos sumeroacadios de la creación". Cultiva afanoso el tema de su primera publicación, Enuma elish cuya traducción publica en 1989 la Universidad Autónoma Metropolitana.

Menciono sus dos publicaciones en el terreno del mundo griego. La primera apareció en Monterrey y en 1967, en las páginas 45-119 del número I de Cuadernos de humanidades. Se intitula "La teogonía hesiódica". La segunda, todavía inconclusa, "Sofistas, dioses y literatura", se ha venido publicando en Estudios de la ciudad de México, número 2, 1985, páginas 77-83; número 3, páginas 91-104 y número 4 de 1986, páginas 49-84. 


\section{MANUEL ALCALÁ}

Pero son más numerosas sus publicaciones —once hasta ahorasobre la literatura latina medieval. Entre ellas descuellan las dedicadas a la monja Rosvitha de Gandersheim. La Sor Juana Inés de la Cruz del siglo X, me atrevo a decir. En el número I de 1966 de los Cuadernos de Investigación Humanística de Monterrey, y en las páginas 175-202, publica "Rosvitha de Gandersheim", Dulcidio (Dulcitius). En la colección Poesía en el Mundo de Monterrey y en 1969 sale de la imprenta Rosvitha de Gandersheim, "Calímaco". Finalmente en 1990 publica en traducción suya y con notas Los seis dramas de la misma monja. Fue una coedición del Fondo de Cultura Económica y el Instituto Tecnológico Autónomo de México.

Me quedan todavía por mencionar ocho publicaciones sobre temas medievales:

"Sponsus": un drama medieval latino-romántico. Colección Poesía en el mundo número 46, 1967, Monterrey. Hay segunda edición de 1969.

"El Danielis ludus de la Catedral de Beauvais", en Humanitas de Monterrey, número 10, 1959, p. 307-325.

El "Ludus de Nativitate" de Benediktbeuern. Colección Poesía en el Mundo, número 80, 1970, Monterrey.

Dramas latinos medievales del ciclo de Navidad, 1970, Monterrey: Instituto Tecnológico y de Estudios Superiores de Monterrey. Es el número 4 de la Serie Letras de las publicaciones de dicho Instituto.

"Peregrinus": Tres versiones, Colección Poesía en el Mundo, número 91, 1971, Monterrey.

Una edición del "Pergamino Vindel", Colección Poesía en el Mundo, número 130, 1978, Monterrey.

El Ordo Virtutum de Hildegard von Bingen", en las páginas 17-52 del tomo II: Literatura del libro Reflexiones Lingüísticas y Literarias editado por R. Olea Franco y J. Valender. 1992, El Colegio de México, Estudios de Lingüística y Literatura, XXI.

Dramas litúrgicos del Occidente medieval, 1992, en Coedición de El Colegio de México, CONACYT y el Instituto Tecnológico Autónomo de México. 
RESPUESTA

Y ahora acaba de ilustrarnos y deleitarnos con su discurso. El glosarlo sería impertinencia mía, pues quitaría el buen sabor que nos ha quedado. No dejo de admirar el perfecto equilibrio de los tres tópicos que lo constituyen.

En el segundo nos ha dado una excelente visión del nacimiento y amplia difusión de la leyenda de Teófilo en el mundo occidental. A propósito del papel de la Mater gloriosa en el Fausto de Goethe ha acuñado, como buen lingüista, la voz actancia. Lo hizo partiendo del francés actante, término del crítico teórico estructuralista francés Greimas. Divide éste al personaje, sea de teatro o de novela en acteur y en actante. El primero es el personaje caracterizado mediante la palabra; el segundo, mediante la acción. Claro que hay personajes que son a la vez acteurs y actantes.

En el tercer tópico nos ha ofrecido su excelente traducción de la versión latina que dan los Acta Sanctorum. Son ellos una recopilación de vidas de santos en la que trabajan desde el siglo XVII los beneméritos Bolandistas. Pudo manejar — nos ha dicho-esa rara edición de 1658 en el rico Fondo de Origen de la Biblioteca Nacional de México.

\section{VI}

Su amplio y sólido humanismo, su buen conocimiento de nuestra lengua, amén de otros méritos, le abrieron las puertas de nuestra Casa como académico electo. Esta noche, por el docto discurso que acabamos de escucharle, es ya académico de número. Y en ese discurso, parte medular ha sido su versión de la leyenda de Teófilo. Versión en la que en excelente español ha conservado el candoroso encanto del latín de la traducción de los Bolandistas.

Por todo ello, me es grato dar a don Luis Astey la bienvenida a nuestra Academia, con el beneplácito y el aplauso de sus colegas. 


\section{LA PROPUESTA}

AGRARIA DE

VENUSTIANO

CARRANZA Y LOS

SONORENSES

(1915-1929)*

Marta García Ugarte**

$\mathcal{H}_{1}$ estudio de la legislación agraria emitida durante los gobiernos de Venustiano Carranza y los sonorenses Álvaro Obregón y Plutarco Elías Calles (1917-1929) muestra que el proyecto de fraccionar las haciendas, o de modificar la estructura de la tenencia de la tierra en México, estuvo sujeto a modificaciones radicales según las presiones sociales (políticas, económicas y militares) propias del momento histórico que se tratare. En cambio, el proyecto de modernización de la producción agrícola elaborado en la última etapa del porfiriato (1904) prácticamente se mantuvo estable hasta la época del general Calles y Cárdenas.

Es de destacar que tanto el Porfirio Díaz de 1904, como Obregón, Calles y Cárdenas, concentraron su atención en fortalecer la agricultura capitalista de exportación. Es decir, aquella que, por la situación económica de los propietarios y la calidad del suelo, podía introducir innovaciones tecnológicas que permitieran incrementar la productividad. Por otra parte, la mayoría de los sectores sociales involucrados en la definición de la política

* Trabajo presentado en la Conferencia Anual (No. 37) de la Western Social Science Association, Land Grand Section, celebrada en Oakland (CA), Estados Unidos, del 26 al 29 de abril de 1995.

** Departamento Académico de Estudios Generales, ITAM. 


\section{MARTA GARCÍA UGARTE}

agrícola gubernamental coincidían en las estrategias y objetivos necesarios para impulsar el desarrollo económico del sector agropecuario.

Las diferencias notables se registraron en torno al principio, sostenido por algunos, de que era imposible impulsar el desarrollo de la agricultura si antes no se efectuaba una transformación radical de la tenencia de la tierra: la hacienda era, se aseguraba, improductiva. Así, antes de que se iniciara el movimiento político de Francisco I. Madero en 1910, la Secretaría de Fomento porfirista empezó a reconocer la necesidad de crear la pequeña propiedad o propiedad de familias. Se debatía entonces la forma de llevar a cabo esa transformación puesto que se esperaban resistencias, explicables, de los grandes propietarios. Las opiniones se dividieron una vez más en torno a la forma de lograr ese fraccionamiento: violenta o moderada.

En ese punto de la discusión, se desencadenaron los hechos revolucionarios que llevaron a Francisco I. Madero a la presidencia de la República. Acontecimientos que pusieron, aún cuando Madero se encontraba distante de un proyecto agrario radical, las demandas de los viejos pueblos indios, que encabezaba Emiliano Zapata, de lograr la restitución de las tierras de sus mayores que habían sido usurpadas por las haciendas. Demanda que se tradujo, en oposición a Madero, en el Plan de Ayala de 1912.

32 Entonces, se retomó el debate agrario que había quedado suspendido en el tiempo. Manuel Bonilla, quien accedió a la dirección de la Secretaría de Fomento en el último trimestre de 1912, asumió la propuesta porfirista de "avanzada": impulsar la pequeña propiedad a través del sistema de "producción familiar" y fomentar un fraccionamiento natural del latifundio mediante políticas arancelarias y productivas que condujeran a la baja el valor de la propiedad raíz. Pero este programa se quedó en suspenso porque, como comenta Fernando González Roa, "se escucharon los primeros cañonazos de la ciudadela". Es decir, la revuelta encabezada por Victoriano Huerta, conocida como decena trágica, que culminó con los asesinatos de Madero y Pino Suárez.

El gobernador de Coahuila, Venustiano Carranza, emitió el Plan de Guadalupe, el 6 de marzo de 1913, que desconocía al presidente usurpa-

${ }^{1}$ Fernando González Roa, El aspecto agrario de la Revolución Mexicana, 1919, México, Poder Ejecutivo Federal, Departamento de Aprovisionamientos Generales, Dirección de Talleres Gráficos, p. 229. 


\section{PROPUESTA AGRARIA DE VENUSTIANO CARRANZA}

dor y a cualquier otro que proviniera del cuartelazo de febrero, y también a los gobiernos estatales que hubieran aceptado su dominio: la Revolución, en su etapa constitucionalista, se había iniciado. En su proceso, el proyecto agrario porfirista entroncaría con el proyecto de restitución de tierras de Emiliano Zapata, y también con la Ley del 6 de enero de 1915 de Venustiano Carranza y la emitida por Francisco Villa.

Antes de entrar en materia, cabe señalar que los proyectos agrarios revolucionarios, y después las legislaciones de los sonorenses y la cardenista, de cobertura nacional, tuvieron un efecto diferente en las entidades federativas. Efectos que, por otra parte, permiten sopesar más objetivamente las pretensiones y propósitos del proyecto agrario mexicano. En esa razón, este trabajo sigue la forma como la legislación agraria se fue entretejiendo con las vicisitudes políticas nacionales y la estructura socio-económica del estado de Querétaro.

\section{Las propuestas agrarias revolucionarias}

En Querétaro no se tenía ninguna intención de fraccionar las haciendas. Esta afirmación es válida aún cuando el hacendado Julián Malo Juvera, quien se había sumado a las filas constitucionalistas en 1914 y al villismo en 1915, había publicado en enero de 1915 un "Proyecto de ley para el fraccionamiento de terrenos". En honor de Malo Juvera, ése fue el único documento agrario queretano antes de 1923 que postulaba el fraccionamiento de la hacienda. Malo Juvera, entonces villista, proponía una expropiación en base al valor que el propietario otorgara a sus terrenos y una "venta" de los lotes a todos los mexicanos "honrados y laboriosos". En su propuesta el fraccionamiento de las haciendas sería un negocio particular, ya fuera que estuviera en manos de los dueños de los terrenos o de compañías formadas ex-profeso para el fraccionamiento. ${ }^{2}$

El proyecto de Malo Juvera, de claras reminiscencias porfiristas, no ejerció influencia alguna en la entidad. Tampoco tuvo impacto la Ley de dotaciones y restituciones del 6 de enero de 1915 emitida por Venustiano

2 Julián Malo Juvera, "Proyecto de ley para el fraccionamiento de terrenos", 1 de enero de 1915, en Marte R. Gómez, La reforma agraria en las filas villistas. Años 1913 a 1915 y 1920, 1966, México, Instituto Nacional de Estudios Historicos de la Revolución Mexicana, p. 224-34. 


\section{MARTA GARCÍA UGARTE}

Carranza ni circuló, por el control político-social que ejercían los hacendados, el Plan de Ayala de Emiliano Zapata. Ciertamente, en Querétaro no había un ambiente favorable a la reforma agraria ni se distribuía información al respecto, puesto que nadie estaba interesado en despertar la "avaricia" de los pueblos indios y los pueblos libres de la entidad que, desde el al menos siglo XIX reiteradamente habían reclamado la devolución de los terrenos que habían sido usurpados por las haciendas. También es cierto que la Comisión Local Agraria, órgano que había sido establecido por la Ley del 6 de enero de 1915 para encargarse de atender las solicitudes de restitución y dotación, sólo había funcionado algunos días debido a la inestabilidad política y militar de ese año. Así, ningún pueblo de Querétăro se acogió a los beneficios de la ley.

No obstante, una vez reinstalada la Comisión Local Agraria en 1916, una vez que los carrancistas ocuparon la plaza de Querétaro que había sido tomada por los villistas, de inmediato tres pueblos se acogieron a la ley del 6 de enero de 1915: Santa Rosa de Jáuregui, pueblo libre de la entidad, y los pueblos Hñahñú, Santiago Mezquititlán del distrito de Amealco, y el barrio de La Magdalena de la municipalidad de Tequisquiapan del distrito de San Juan del Río.

Pero entonces, se había decidido no poner trabas al desarrollo agrícola de los hacendados de Querétaro, estado que se había convertido en uno de los graneros del gobierno que encabezaba Venustiano Carranza. ${ }^{3}$ En ese propósito, y con el deseo de evitar que otros pueblos solicitaran demandas de restitución, los tres poblados enfrentaron el mismo dictamen: según el perito evaluador, los documentos presentados para hacer valer los derechos de propiedad de los pueblos eran "apócrifos pues ni por su aspecto, ni por el papel en que están escritos, letra de ellos y la fecha en que aparecen otorgados merecen ningún crédito respecto a su autenticidad".

En el bienio 1916-1917, tanto las autoridades militares (carrancistas) como los hacendados de Querétaro temían que se despertara el viejo

${ }^{3}$ De hecho, Venustiano Carranza había dispuesto, en 1916, que no se procediera al reparto de la tierra. Romana Falcón reseña que, "a principios de 1916, Carranza prohibió a las autoridades agrarias estatales alterar o reglamentar la Ley del 6 de enero de 1915...mientras enfatizó que, como la reforma a la propiedad rural estaba en su primera fase, aún no se procedería a distribuir la tierra". Romana Falcón, Revolución y caciquismo. San Luis Potosí, 1910-1938, México, El Colegio de México, 1984, p. 141. 


\section{PROPUESTA AGRARIA DE VENUSTIANO CARRANZA}

anhelo indígena de recuperar las tierras usurpadas por las haciendas, tanto desde tiempos "inmemoriales" como durante la década 1870-1880 cuando los hacendados habían extendido los límites territoriales de sus propiedades a fin de acaparar el recurso agua. ${ }^{4} \mathrm{De}$ ahí que los miembros de la Junta Local Agraria, coaligados con el grupo de los hacendados, aceptaran que los títulos de propiedad presentados en 1916 eran falsos.

Sorpresivamente, los habitantes de la cabecera distrital villa de Colón pidieron dotación de tierras en ese mismo año. En ese entonces, 1916, la villa de Colón tenía 624 jefes de familia que podían ser dotados. Algunos de ellos eran propietarios de "lotes" dedicados a la agricultura y otros se dedicaban la compra-venta de ganado. Es decir, se trataba de una comunidad de rancheros, próspera como otras de la entidad, que mantenía vínculos con las haciendas comarcanas. Los dueños de las haciendas que podían ser afectadas, Pedro Gorozpe, el propietario de la hacienda de Ajuchitlán y sus anexas, El Rosario y Panales, y el del rancho Santa María de Guadalupe o El Mexicano, alegaron en su defensa que los habitantes de Colón no podían solicitar dotación de tierras porque no tenía la categoría política que había determinado la Ley del 6 de enero de 1915, es decir, no se trataba de una población de escasos recursos. Además, las susodichas fincas ya habían sido fraccionadas.

Es claro que se quiso impedir que la solicitud de los rancheros de la villa de Colón prosperara, puesto que bajo su ejemplo se corría el riesgo de que todos aquellos individuos que habían sido dotados de tierras por las leyes liberales de mediados del siglo XIX también hicieran solicitudes de dotación para ampliar sus ranchos. Y era muy difícil rechazar esas solicitudes porque los dotados por las leyes liberales se habían asentado en poblaciones nuevas, "libres". Es decir, sus viviendas no se localizaban en terrenos que eran propiedad de las haciendas como pasaba con muchas rancherías o lugar de asiento de los peones y medieros de las fincas rústicas. Por esa independencia, y según la Ley del 6 de enero de 1915 , podían ser dotados. En tal situación estaban los pobladores de El Sitio, Corral Blanco (años más tarde denominada Ezequiel Montes), Arroyo Seco (en 1904 denominada Pedro Escobedo) y Concá, situado a la vera de la hacienda San Nicolás Concá.

${ }^{4}$ Cfr. Marta Eugenia García Ugarte, Hacendados y rancheros queretanos (1780-1920), 1992, México, Consejo Nacional para la Cultura y las Artes. 


\section{MARTA GARCÍA UGARTE}

La fuerza económica que disfrutaban estas sociedades de rancheros y los vínculos que sostenían con las haciendas, puesto que fungían como medieros, administradores, mayordomos "mandones" y hasta de peones de las fincas rústicas podía empujarlos, si observaban que había una vía institucional para lograrlo, a demandar las tierras de las haciendas que trabajaban como medieros o arrendadores, que generalmente, colindaban con sus fajas y labores de tierra. Era previsible además que si los rancheros ampliaban los límites de sus propiedades, las haciendas perderían no sólo parte de sus terrenos sino también una fuerza de trabajo, la más importante, puesto que los propietarios asumirían los puestos administrativos.

No obstante, los rancheros tardaron en organizar sus peticiones de tierras porque no conformaban un grupo unificado. Además, la Junta Local Agraria de 1916 se desintegró ese mismo año porque todos los miembros que la constituían -elementos de la clase media urbanarenunciaron el 21 de junio de 1916 . En apariencia, esa renuncia masiva se debió a que nadie quería ser parte de un organismo que entraba en contradicción abierta con el poderoso grupo de los hacendados. Así, de 1911 a 1917 en el estado de Querétaro nada se había hecho en materia agraria.

Aún después de emitida la Constitución de 1917, la del país y la local, las solicitudes de tierras seguían siendo de restitución (once en sólo

36 cuatro meses) y solamente se presentó una de dotación. Todas ellas rechazadas en 1919, con excepción de la petición de Santa Rosa de Jáuregui, porque Pastor Rouaix, secretario de Agricultura y Fomento, había asentado, en una circular del 21 de marzo de 1918, que no obstante que era "urgente" proveer de tierras para sembrar a los labradores pobres, ese reparto no era posible "por ahora", hasta que no se contara con la ley reglamentaria del artículo 27 constitucional. Sólo se podían otorgar tierras de acuerdo a la Ley del 27 de noviembre de 1896 y su respectivo reglamento del 6 de septiembre de 1897, que ordenaba el reparto individual de las tierras comunales y reconocía como labradores pobres aquellos cuyas propiedades valieran $\$ 200.00$. La misma que había sido duramente criticada por Andrés Molina Enríquez en su conocida obra Los grandes problemas nacionales, porque era prácticamente imposible "medir" terrenos tan pequeños. Con esta disposición, el carrancismo iba en contra de las disposiciones de la Ley del 6 de enero de 1915 que había autorizado a las autoridades militares de cada lugar a efectuar 


\section{PROPUESTA AGRARIA DE VENUSTIANO CARRANZA}

"las expropiaciones que fueran indispensables" para dar tierras a los que carecían de ellas.

De manera independiente a las restricciones que existían en 1919, la petición del pueblo de Colón fue retomada. Entonces, se decidió dotar a solicitantes con 877 has. con terreno cerril y de mala calidad, que se tomaría de la hacienda El Lobo y sus anexas, que tenían una extensión de 36170 has. y de Ajuchitlán, que medía 20,000 has. ${ }^{5}$ De tal manera que las 556 has. que se quitarían al Lobo y las 312 que se tomarían de Ajuchitlán eran inferiores a las extensiones de los pejugales que entregaban los hacendados a los medieros como parte del salario que devengaban.

Mientras el pueblo de Colón recibía esa dotación irrisoria, la solicitud del Pueblito, antiguo pueblo novohispano, fue rechazada porque los solicitantes eran, decían los hacendados, propietarios prósperos que sólo estaban interesados en apropiarse de las tierras irrigadas que colindaban con sus terrenos. Además, la mayoría de las haciendas que podían ser afectadas (las de Tejeda, El Cerrito, La Negreta y Balvanera) se encontraban fuertemente endeudadas por créditos que habían invertido en infraestructura de riego. Así, para proteger la agricultura de esta microregión, fue rechazada esta solicitud. Además, en una interpretación de la ley del 6 de enero de 1915 y del artículo 27 constitucional que perduró hasta 1940, los integrantes de la Comisión Local Agraria asentaron que el propósito de las leyes agrarias no era "convertir en propietarios de tierra a todos los habitantes de los pequeños poblados de la República, máxime, cuando tales habitantes como en el presente (villa del Pueblito) constituyen un factor imprescindible de la producción en grande escala cuyo fundamento es tan necesario". 6 Principio que enarbolaban los hacendados, y que incluso en la cúspide del reparto agrario 1934-1937 tuvo que considerar el presidente Lázaro Cárdenas.

La razón por la que en 1919 se negó la restitución de tierras solicitadas por los pueblos otomí de Amealco expresa que se tenía claro, como en la última etapa del porfiriato, que la restitución de las tierras no resolvía el "problema angustioso de los pueblos". Para que la política agraria fuera efectiva era preciso que de manera simultánea se iniciaran las obras

${ }^{5}$ Diario Oficial del estado de Querétaro, La sombra de Arteaga, 17 de enero de 1920.

${ }^{6}$ Comisión Nacional Agraria, 31 de ocubre de 1919. Publicado en La sombra de Arteaga del 20 de diciembre de 1919. 


\section{MARTA GARCÍA UGARTE}

de riego, puesto que los vecinos de los pueblos indios "se conformaban" con el mísero salario que fluctuaba entre 12 y 25 centavos, para el cuartillo de maíz, porque sus tierras no producían lo suficiente para sostenerlos dado que eran de temporal y de mala calidad. También se sostuvo, en una contradicción con el planteamiento anterior, que todavía había suficiente tierra comunal para repartir a nivel individual. Se continuaba así la política agraria porfirista (reglamento de 1878) que había ordenado la titulación individual de los terrenos comunales. Bajo esas resoluciones, los habitantes de los pueblos de Colón, Boyé y San Pablo, desistieron de sus solicitudes.

La única dotación de tierras que se concedió en 1919, además de la restitución otorgada a Santa Rosa de Jáuregui, tuvo un origen político. Se trató de los habitantes del antiguo Arroyo Seco, el actual Pedro Escobedo, pequeños comerciantes que para mejorar sus ingresos habían solicitado las tierras de las haciendas comarcanas (El Ahorcado, San Clemente, El Sauz, La Lira y el rancho Arroyo Seco).

En este caso, los hacendados intervinieron directamente asegurando a los habitantes de Pedro Escobedo que de seguir con sus pretensiones agrarias, les quitarían el acceso a las aguas del Río San Juan que controlaban las mencionadas haciendas y nunca más volverían a ser ocupados (contratados) por las haciendas. Tal manifestación ponía en evidencia que el control del estado seguía estando en manos de los hacendados y no del poder político revolucionario. Incluso para los carrancistas, lejanos de los postulados agrarios, era inaceptable que un grupo de particulares se pusiera por encima de la jurisdicción gubernamental, como se desprendía de las declaraciones de los hacendados sanjuanenses. De ahí que se decretó que era procedente la dotación del pueblo de Pedro Escobedo porque "era un grupo explotado por las haciendas". En realidad no era así pero, ¿qué otra justificación podían escoger?

Es claro que los esfuerzos históricos de los pueblos indios y los rancheros en nada coincidían con las pretensiones locales y federales del carrancismo. Hasta 1920, las dos resoluciones favorables concedidas en el estado de Querétaro pueden considerarse simbólicas y representativas de una intención revolucionaria poco interesada en expresarse en cambios concretos en la tenencia de la tierra. Pese al artículo 27 constitucional, el gobierno federal, el de don Venustiano Carranza, carecía de un proyecto agrario. 
La falta de visión de los carrancistas, o su ceguera para medir la importancia que tenía para la estabilidad política y el desarrollo del país el fraccionamiento de los latifundios, la fundación de instituciones de crédito, la infraestructura para la producción (obras de ingeniería hidráulica, caminos) y el fortalecimiento de la educación de los productores rurales no es sorprendente. En todo caso, era una consecuencia de la situación del país, que demandaba todos los esfuerzos para lograr su pacificación. También reflejaba las diferencias que existían en torno a las formas, radical o violenta, de realizar el fraccionamiento de las haciendas y sobre el sistema de tenencia que se deseaba instrumentar: la pequeña propiedad en coexistencia pacífica con la gran propiedad, como era el proyecto porfirista de 1902, o la restitución y dotación de las tierras comunales a los pueblos como pretendía el Plan de Ayala de Emiliano Zapata que, aunque Luis Cabrera dice que no se conoció hasta el triunfo de la Revolución sobre el huertismo (en 1914), influyó para que se enfatizara la necesidad de convertir a los peones en colonos libres que cultivaran su propio campo con sus familias. También circulaba la Ley agraria de Villa que fundamentaba el fraccionamiento de los latifundios no en razón de la pequeña propiedad sino en cuanto superficie máxima de terreno que podía disponer un sólo dueño. Cantidad que sería delimitada en función del riego, la densidad de la población, la calidad de las tierras "y todos los demás elementos que sirvan para determinar el límite más allá del cual la propiedad llegara a constituir una amenaza para la estabilidad de las instituciones y para el equilibrio social". Los villistas aspiraban, como registrara Antonio Díaz Soto y Gama en 1959, "a la posesión de una unidad agrícola que mereciera el nombre de rancho y no a la parcela paupérrima del ejido". 7

Tales programas y propósitos estaban firmemente asentados en el México de la Revolución. En ese sentido, la inmovilidad de los carrancistas en materia agraria también se debía a que la política agraria se había dejado en manos de Pastor Rouaix quien, desde el triunfo maderista, había hecho suyo el proyecto porfirista más conservador. Por su parte, Manuel Bonilla, quien había sido Secretario de Fomento en el

${ }^{7}$ Antonio Díaz Soto y Gama, La cuestión agraria en México, 1959, México, Instituto de Investigaciones Sociales, Universidad Nacional Autónoma de México, p. 29. 


\section{MARTA GARCÍA UGARTE}

último trimestre de 1912, elaboró el proyecto de Ley Agraria del estado de Chihuahua, apegado a los principios porfiristas. Tanto es así, que Marte R. Gómez, quien elogiaba los méritos revolucionarios de Bonilla y su leältad al maderismo, reconocía que el agrarismo de don Manuel "era comedido" porque consideraba que expropiar era "incurrir en actos de violencia". 8

Bajo una u otra concepción, en 1920 todas las fuerzas revolucionarias y políticas del país reconocían que el problema agrario ameritaba una resolución rápida y expedita. Sin embargo, frente a la necesidad de estabilizar el país, el carrancismo parecía desconocer la "urgencia" de resolver la problemática del agro mexicano y tampoco demostraba interés en cambiar el régimen de la tenencia de la tierra ni siquiera en el sentido de la pequeña y mediana propiedad. En todo caso, después del Plan de Agua Prieta, que condujo al desastre el gobierno y la vida de Venustiano Carranza, se abrió camino la preocupación moral por las condiciones de los trabajadores rurales y por la explotación sistemática de los contratos de aparcería.

\section{La propuesta agraria y agrícola de los generales Álvaro Obregón y Plutarco Elías Calles}

Los diferentes documentos publicados sobre la explotación de los trabajadores rurales no alcanzaban a reflejar el derecho que tenía el patrón de utilizar la fuerza de trabajo del aparcero ni la serie de estipulaciones por las cuales, de una u otra manera, el mediero siempre salía perdiendo frente a la hacienda. Mucho menos reconocían que mientras existieran los contratos de aparcería (a medias, al quinto y al rajar) permanecerían idénticos los pilares que permitían la explotación de la gran propiedad. Condición que expresa que, en realidad, no se tenía ninguna intención de lesionar el sistema de la hacienda. De ahí que, lejos de instrumentar un proyecto agrario, se empezaron a emitir leyes reguladoras de la aparecería que dejaban intactos los factores laborales y productivos que sostenían el régimen de la gran propiedad.

Éste fue el caso de la Ley de tierras ociosas, publicada el 23 de junio de 1920 por Adolfo de la Huerta, presidente interino de la República al

${ }^{8}$ Marte R. Gómez, Op. cit. p. 106. 


\section{PROPUESTA AGRARIA DE VENUSTIIANO CARRANZA}

triunfo del Plan de Agua Prieta. Ley que, generalmente, ha sido identificada como una de las primeras disposiciones agrarias después del revolucionario artículo 27 . No obstante, la misma no tenía un propósito agrario sino productivo, puesto que obedecía a la intención de incrementar la productividad agrícola. Por otra parte, no disponía elementos novedosos para organización de la producción puesto que se fundamentaba en la aparcería que era el sistema tradicionalmente usado por la hacienda. Asimismo contenía el propósito político de otorgar una fuente de financiamiento a los municipios a fin de fundamentar su autonomía política.

También es cierto que Álvaro Obregón, como los otros dos sonorenses que encabezaron el Plan de Agua Prieta, Adolfo de la Huerta y Plutarco Elías Calles, consideraba que la reforma agraria debía encaminarse por la pequeña propiedad y que el fraccionamiento del latifundio debía realizarse ordenadamente y de acuerdo con los intereses económicos del país. Esa postura había sido clara en el discurso que sostuvo el general Obregón en la Cámara Agrícola del estado de Jalisco en el cual había condenado la improvisación y la falta de visión con que algunos generales estaban fraccionando el latifundio y destruyendo negociaciones agrícolas de importancia para el futuro económico del país.

Es claro que el gran proyecto del presidente era mejorar las condiciones técnicas de producción (la irrigación, el crédito, la organización de productores, el mejoramiento de las semillas y formas adecuadas de comercialización que incrementaran los ingresos del productor) y orientar la reforma por la pequeña propiedad. Era entonces, un programa de progreso agrícola y no de reforma agraria. Incluso el proyecto de Ley sobre el fraccionamiento de los latifundios presentado a las cámaras el 9 de febrero de 1921 "protegía" aquellas negociaciones agrícolas "que tuviesen establecidos sistemas modernos de cultivo".

No obstante, Obregón no podía dejar de satisfacer las demandas agrarias de los hombres del campo, porque ellos habían sido sus grandes aliados, junto a los obreros, cuando el Plan de Agua Prieta. Además, un programa agrario suave y bien dirigido restablecería la unidad revolucionaria que se había perdido con los acontecimientos de Tlaxcalaltongo, cuando perdió la vida el presidente Carranza. De ahí que el Reglamento agrario del 10 de abril de 1922 abrió las puertas para que los centros de población que no estaban situados en terrenos de las haciendas pudieran solicitar dotaciones de tierra. Es decir, podían solicitar tierras los grupos 


\section{MARTA GARCÍA UGARTE}

rancheros que se habían sumado al Plan de Agua Prieta quienes, por otra parte, habían sido armados por el gobierno federal.

Con fuerzas armadas propias y con una legislación favorable, los rancheros se atrevieron a solicitar las tierras que trabajaban a medias con la hacienda. Tal fue el caso de los rancheros de Concá, de la Sierra Gorda del lado queretano, quienes no sólo solicitaron las tierras de la hacienda de Conca sino que, amparados por las armas y porque ocupaban los puestos políticos del municipio y del poblado, las ocuparon antes de que se emitiera la resolución agraria. El proceso, iniciado en 1921, tardó cinco años en resolverse tanto por la renuencia regional como por la intervención de la Embajada norteamericana, dado que San Nicolás Concá estaba en propiedad de un ciudadano norteamericano, Alejandro S. Sharpton.

Es de señalar que excepto la de Concá, ninguna otra sociedad ranchera de la entidad se acogió a esta ley. La pasividad de los rancheros de los valles queretanos encuentra su explicación en las condiciones altamente productivas de esta región, donde desde el porfiriato se habían venido realizado fuertes inversiones en infraestructura de riego. De esa manera, los hacendados de los valles podían acogerse a las disposiciones del reglamento obregonista que protegía las unidades agrícolas productivas y las propiedades de los hacendados que no temían invertir en la adquisición de nueva tecnología. Propósito que determinó la decisión de poner candados al reglamento agrario a fin de que los peones y trabajadores de las fincas no pudieran pedir dotaciones con el propósito de "preservar" la fuerza de trabajo de las unidades agrícolas.

Por otra parte, el reglamento ponía fin a los repartos de tierras de mala calidad, que había sido una constante revolucionaria, a la vez que protegía la pequeña propiedad. Así, aún cuando establece el minifundio, éste variaba de tamaño según si se tenía o no posibilidad de riego. ${ }^{9}$

Así, se trataba de una reforma agraria moderada que no pretendía destruir la base agrícola que sostenía la hacienda. Se iban a repartir tierras ciertamente, pero sin atentar contra la industria agrícola y ganadera del país que era exitosa y la dotación se haría de manera gradual. Puede obser-

${ }^{9}$ La extensión de los ejidos era de tres a cinco hectáreas en los terrenos de humedad o de riego; de cuatro a seis en los terrenos de temporal con precipitación pluvial abundante y de seis a ocho en aquellas tierras de temporal de otras clases. Cantidades que podían aumentarse hasta el triple cuando se tratara de terrenos cerriles o áridos. 


\section{PROPUESTA AGRARIA DE VENUSTLANO CARRANZA}

varse que el general Obregón no tenía la intención de afectar de manera seria los grandes latifundios productivos. Pero, al mismo tiempo, se deseaba favorecer a la población rural que había sido, y seguía siendo, uno de los principales soportes de los gobiernos revolucionarios.

Las puertas que abrió el régimen de Obregón para una mejor organización del mundo rural no fueron aprovechadas por la dirigencia política queretana, todavía renuente a tocar una de las fuentes de trabajo más lucrativas de la entidad. La única petición agraria que cruza el período 1920 a 1925, la de los rancheros de Concá, se encuentra estrechamente relacionada con los afanes de poder de cada uno de los cinco gobernadores que se sucedieron de 1920 a 1925 , que necesitaron de las fuerzas armadas de los rancheros para sostener sus gobiernos. Pero ante todo, se debió a los alientos y aspiraciones de los rancheros armados, que por primera vez se encontraron en posibilidad de enfrentar el poder hegemónico que desde finales del siglo XIX ejercían los hermanos Olvera en la región serrana.

Es innegable que los dirigentes políticos queretanos, que provenían de la clase media y aristocrática, no tenían ninguna intención de fraccionar la hacienda. Tan sólo se preocuparon por mejorar las condiciones de trabajo de las fincas rústicas, disposiciones que en nada contribuían a modificar el régimen de la tenencia de la tierra. Esta posición quedó establecida en la reglamentación agrícola que contiene la Ley del trabajo que fue emitida en diciembre de 1922 por la XXV legislatura local que sólo regulaba las prácticas tradicionales que habían permitido la existencia de la hacienda: la mediería, las jornadas de trabajo, los salarios en especie.

Los acontecimientos políticos y militares de la última etapa del gobierno del general Obregón, por la "imposición" de la candidatura del general Plutarco Elías Calles, que desencadenaron la revuelta delahuertista, pusieron a discusión el proyecto de nación con la misma intensidad y ambigüedad que durante el proceso revolucionario. De 1923 a 1931, en que se sucedieron tres revoluciones (delahuertista, cristera y de Escobar) y se conformó el período conocido por los historiadores como "el maximato", ${ }^{10}$ cambió el ritmo de la historia en todos los ámbitos de la vida política y social.

${ }^{10}$ Para enfatizar el predominio político que ejercía el general Plutarco Elías Calles y la debilidad de los presidentes que sucesivamente ocuparon el Poder Ejecutivo después del asesinato del general Obregón en 1928: Emilio Portes Gil, Pascual Ortiz Rubio y Abelardo Rodríguez. 


\section{MARTA GARCÍA UGARTE}

Los enfrentamientos y divisiones militares, tanto en 1920 como en 1923,1927 y 1929 , fueron determinantes para que los presidentes Obregón y Calles recurrieran a la formación de fuerzas armadas no militares que eran reclutadas entre los únicos grupos que entonces estaban dispuestos a "jugar" con el gobierno federal para defender el orden constitucional: los rancheros, peones y medieros del sector rural. De esa manera, la federación, el "Supremo Gobierno" como todavía dicen los hombres del campo, se vio comprometida con los intereses y causas del sector rural popular mientras dejaba de lado los de aquellos que eran los más aptos para gobernar o para llevar a cabo el proyecto que encabezan los sonorenses: la clase media y la aristocracia terrateniente, comercial e industrial.

Esa transformación socio-política que significó el relegamiento de la clase dirigente (aristocracia y profesionistas) del poder y el ascenso de los rancheros, también condicionó el proyecto de desarrollo económico que tenían los sonorenses. En particular el del general Calles, precisamente porque fue durante su administración cuando por los conflictos que se tuvieron que enfrentar - guerra cristera e inestabilidad política generada por el asesinato de Álvaro Obregón en 1928- los rancheros armados alcanzaron mayor fuerza y poder: ellos se convirtieron en uno de los pilares más sólidos del partido naciente, el PNR, y del sistema político que se perfilaba. Como consecuencia, en 1929 el proyecto agrícola para el país diseñado durante el régimen de Obregón y Calles, se trastocó radicalmente en un proyecto agrario. Dicha transformación no pudo realizarse de manera pacífica tanto por la oposición de los propietarios y las demandas de los rancheros como porque los dirigentes nacionales se encontraban divididos: ¿Cuál era la mejor forma de impulsar el desarrollo de la agricultura, actividad fundamental de la nación? De hecho, era el mismo interrogante que se habían formulado los porfiristas en 1902.

Para Calles, la solución al problema de la agricultura estaba en la irrigación y el crédito oportuno, que también eran parte esencial de los planes agrícolas discutidos por el personal de la Secretaría de fomento entre 1902 y 1910 . Por eso se creó la Comisión Nacional de Irrigación para "promover y construir obras de irrigación en la República" el 4 de enero de 1926, y la Ley de Crédito Agrícola publicada el 10 de febrero del mismo año. De manera paralela, se emitió la Ley de Colonización, 
del 5 de abril de 1926, que reglamentaba la fragmentación de las propiedades privadas con excepción de las que tuvieran una adecuada explotación agrícola, aquellas que constituyeran una "unidad agrícola" con tecnología moderna y las que eran cultivadas por una administración directa, es decir, que no recurrían al arrendamiento de los terrenos.

Esas especificaciones delimitaban, de una forma indirecta, que la propiedad agrícola que se tenía en mente era la pequeña propiedad porque ningún latifundio, por su extensión, podía ser trabajado con una administración directa. Así, la Ley de Colonización era un elemento clave en el proyecto de desarrollo agrícola concebido por el general Calles: crear una legión de agricultores, con buenas tierras, modernos, capitalistas, que contaran con una infraestructura para el desarrollo (irrigación, caminos, establos, bodegas) y apoyos institucionales (crédito, tecnología, estímulos fiscales). Era un plan agrícola seria y concienzudamente formulado, que permitiría la expansión económica del sector, la autosuficiencia alimentaria y un mejor balance comercial internacional.

Aún la corriente que fue identificada con el "agrarismo", aquella que buscaba convertir a peones y medieros en agricultores, como pretendía la ley de dotaciones y restituciones de tierras y aguas, publicada durante la administración de Emilio Portes Gil el 21 de marzo de 1929, respetaba la pequeña propiedad: los terrenos que serían afectados para dotar a los solicitantes de tierra serían parte del territorio de las haciendas vecinas y nunca de los ranchos o pequeña propiedad.

Hasta 1929 no había una diferencia notable entre posiciones callista y de Portes Gil, que encabezaba el grupo que se autodefinía como agrarista. No obstante, ya estaban en marcha los dos proyectos para el agro mexicano que se enfrentaran abiertamente durante el cardenismo: el agrícola y el agrario.

\section{Epílogo: breves reflexiones sobre el reparto agrario cardenista}

Como fuerza social en ascenso, la de los rancheros, estaba vinculada por su origen y situación con el proyecto agrario que encabezaba el presidente interino Portes Gil, y fue la corriente que se impuso en medio de una gran violencia en la década de los treinta, el año en que los grupos rancheros de Querétaro lograron unificar sus fuerzas y proponer como 


\section{MARTA GARCÍA UGARTE}

candidato a la gubernatura a uno de sus líderes, el peón de los valles, Saturnino Osornio.

Apoyado por las fuerzas rancheras de la entidad, y por el grupo callista de la capital de la República, Osornio asumió la gubernatura de Querétaro en 1931; no obstante, no estaba interesado en impulsar un proyecto agrario minifundista. Por el contrario, sus esfuerzos se concentraron en conformar una organización sindical rural que obligara a los hacendados a cumplir con las disposiciones laborales del artículo 123 . Sus pretensiones y la eficacia de sus "organizados", más de 10,000 campesinos en la entidad, en escasos cuatro años de gobierno (1931-1935) desestabilizaron los esquemas tradicionales del trabajo agrícola: empezaron a predominar los trabajadores asalariados, sin vínculos afectivos con la hacienda y sin pagos en especie. El latifundio, basado en el trabajador de tarea (los medieros) y en los peones apadronados y acasillados, no podía sobrevivir bajo las nuevas condiciones laborales que demandaban una nueva organización social del trabajo y la propiedad.

Desafortunadamente, los hacendados queretanos no fueron sensibles a los cambios. Su incapacidad para adecuarse a las nuevas formas de producción del proyecto callista determinó la tragedia que vivieron en la década de los treinta, cuando se empantanaron en la defensa de la propiedad que irremediablemente perdían por los adeudos acumulados

46 y no tanto, como ellos aseguraban, por las pretensiones agraristas del gobernador. De hecho, Osornio sólo estimuló el reparto agrario cuando los propios trabajadores planteaban la iniciativa, de manera intensiva al final de su período (1934-1935) para favorecer a los hombres que lo habían acompañado en su gobierno, una vez que fue claro que el presidente Lázaro Cárdenas no estaba dispuesto, por el conflicto con el ex-presidente Calles, en seguir apoyando al grupo osornista de clara filiación callista. Hasta 1935 no se inició el reparto de las haciendas queretanas bajo la forma del ejido que había establecido el Código Agrario de 1934. Es de señalar que el reparto agrario continuó en Querétaro en medio de una gran violencia hasta 1937, cuando el presidente Cárdenas, en un giro todavía no suficientemente investigado, empezó a estimular la expansión de la pequeña propiedad.

Aún cuando habría que hacer una investigación específica, puede considerarse que la emisión del Código Agrario en marzo de 1934, que ordenaba la legislación ejidal, representó cl triunfo de los radicales, que 


\section{PROPUESTA AGRARIA DE VENUSTIANO CARRANZA}

señalaban así su diferencia con el callismo. Sin embargo cabe preguntarse, ¿́acaso la radicalización del reparto agrario durante los primeros años del cardenismo (1934-1937) responde a la composición ideológica del grupo en el poder heredada de la crisis de 1928? ¿Acaso el viraje agrario que se inicia a fines de 1937, cuando se abandona el reparto ejidal y se inicia la defensa de la pequeña propiedad, responde al hecho indudable de la consolidación del poder presidencial de Lázaro Cárdenas?

Es un hecho todavía no suficientemente documentado que Cárdenas retomó, una vez expulsado el ex-presidente Calles del país, el proyecto agrícola que habían encabezado los sonorenses. Ese viraje lleva a preguntarse si en 1937, ya que se habían desmantelado las fuerzas rurales de filiación callista y satisfechos los intereses de los grupos rurales organizados del país que acaban por agruparse en una sola central de clara identidad cardenista, la CNC (Central Nacional Campesina), se podía retomar el proyecto agrícola que del porfiriato al callismo se había querido llevar a cabo en el país.

En suma, las fuerzas triunfantes de la Revolución constitucionalista, carrancistas y sonorenses, asumieron un plan agrícola que permitiera impulsar el desarrollo capitalista de la agricultura mexicana. No obstante, por los compromisos políticos y militares adquiridos con el sector rural que se sumó a las propuestas gubernamentales oficiales, los rancheros, se vieron obligadas a impulsar una reforma agraria moderada que concentraba su atención en la pequeña propiedad. Es claro, al menos para el caso de Querétaro, que la formación del ejido, de escasa extensión, sólo alcanzó difusión en 1929 cuando el futuro de la nación, por los acontecimientos políticos de 1928, se había puesto en entredicho, y en 1934 cuando fue utilizado como un factor de cohesión de las fuerzas rurales que se sumaron al cardenismo.

Así, puede sostenerse que el programa agrario o el esperado fraccionamiento del latifundio que se inició en 1929 , estuvo preñado de una fuerte carga política. De esa manera perdió la importancia estratégica que se le había concedido, desde el porfiriato hasta el gobierno de Plutarco Elías Calles, como parte integral de un proyecto ambicioso de modernización de la actividad agropecuaria. 


\section{ENTREVISTA A EDUARDO MILÁN* \\ Eduardo Aguilar**}

\section{El lugar de la Poesía}

Milán, ¿cuál es el momento de la poesía hispanoamericana y cómo se explicaría dentro de ese momento tu libro: Nivel medio verdadero de las aguas que se besan?

Visto desde aquí, desde México, el momento de la poesía hispanoamericana es para mí muy confuso. Y se trata de una doble confusión, primero porque es una confusión latinoamericana, en cuanto al Continente; y es una confusión que se integra a una confusión general que padece toda manifestación que pueda llamarse arte en la actualidad.

El arte está en confusión porque ha dejado de tener la función que tenía; ya no es, ya no está en el lugar que aparentemente intentó colocarlo el Renacimiento, que es el lugar de una usurpación...

La firma de la obra de arte en el Renacimiento significa el pasaje del arte de un lugar a otro; es decir, la intención de crear un lugar para el arte, que nunca pudo cuajar.

Y la prueba de ello es el intento de restituir al arte un lugar que nunca tuvo en esa misma sociedad. Es un producto directo del Renacimiento, pasado por el Siglo de las Luces.

En cuanto a la segunda confusión señalaría lo siguiente: yo no me atrevería a decir que la poesía latinoamericana es un reflejo claro de otro tipo de poesías. Es más, no incluiría a la poesía latinoamericana dentro de la poesía de la lengua, me refiero a que no haría una asimilación España-Latinoamérica por el simple hecho de hablar la misma lengua, o

* Departamento Académico de Estudios Generales, ITAM.

** Departamento Académico de Estudios Generales, ITAM. 


\section{EDUARDO AGUILAR}

porque somos un continente conquistado por España. No, yo creo que la poesía está un poco al margen, o salida del territorio de la lengua. Y es un problema de la poesía como práctica general. Es decir, el problema de lugar de la poesía. Desde dónde se hace, desde dónde se practica esa poesía? Desde Latinoamérica, que es un continente desprevenido - digamos así- en cuanto a las influencias que recibe. Porque primero fue la influencia española, después fue la influencia francesa, ahora es la influencia estadounidense. En general, si nosotros estamos abiertos a todo ese tipo de influencias, no hay nada, creo yo, que pueda legitimarnos como un continente diferente respecto a las tendencias hegemónicas del momento, en relación a la ideología dominante del mundo occidental, que es una. No hay nada que nos aparte de ahí, salvo lo que podemos considerar como nuestra tradición. Y depende, también, de a qué llamaremos nuestra tradición.

¿Dónde empieza? Yo sé donde empieza nuestra tradición a nivel de poesía lírica latinoamericana: empieza con Darío. Él es el hombre que rompe la frontera de Latinoamérica y coloca a la poesía latinoamericana dentro de Europa, y es reverenciado por los españoles; porque hizo un truco de tipo formal, que es el siguiente: las formas utilizadas por Darío dentro de la lengua pertenecen a la poesía francesa, y no a la poesía española; Latinoamérica entra a Europa no por la puerta de España, sino

por la puerta de Francia traducida al español; eso es Rubén Darío, en parte, como actitud ante la lengua.

¿Cómo ubicarías entonces a Dario, en este no lugar del arte, en esta nueva mediación que no le corresponde, hasta cierto punto, al arte?

Cuando yo digo usurpación estoy hablando de la traducción, del pasaje de lo sagrado a lo profano, es decir: del arte que intenta ocupar, como mediación, el lugar de una mediación anterior, que era la del arte religioso, el arte icónico medieval, que se reconocía como usurpación, es decir, el ícono decía estoy mediando. En el Renacimiento la obra ya no dice: estoy mediando, está diciendo: yo soy este lugar, yo ya no estoy en el medio, estoy en el centro... Por eso aparece la firma, por eso digo que el lugar es lo que ahí está en entredicho.

Ahora, dentro de esta práctica de no lugar, Rubén Darío circula con la lógica, la misma lógica de no lugar. Es decir, un hombre no cambia la 


\section{ENTREVISTA A EDUARDO MILÁN}

lógica de un fenómeno, él lo único que hace es, dentro de la lógica de no lugar, conseguir un pseudo lugar latinoamericano en Europa. Él es el fundador de la presencia latinoamericana en Europa. Después viene la vanguardia: Huidobro, Girondo, Vallejo, Pablo Neruda, que establecen lo que podría llamarse la presencia de la poesía latinoamericana en general. Pero Darío es el que abre todo. Y lo abre desde la lógica de no-lugar, no desde la lógica de lugar. Ésta es la segunda confusión.

En consecuencia, ¿Latinoamérica con la poesía latinoamericana, la poesía que se hace desde acá, continuaría siendo un continente desprevenido?

\section{¿Hoy?}

Sí, hoy.

Sería desprevenido si no hubiera habido, por ejemplo, aportes de fenómenos como el de la Poesía Concreta brasileña, que aunque pertenece a otra lengua es un fenómeno absolutamente crítico y que toma como bandera justamente el desnivel en que está situada la poesía latinoamericana, la poesía de la "colonia" - para decirlo así- en relación con la "metrópoli". A través de la lectura que hacen ellos del Manifiesto Antropofágico de 1928 de Oswald de Andrade, un poeta brasileño que plantea las cosas así: si nosotros somos colonizados, la única manera de competir con el mercado es en los términos del mercado. Canibalizar los productos, la materia prima ideológica del mercado y reelaborar a nivel local, transgrediendo todos los órdenes y los sistemas e imponiendo un producto nuevo con la misma lógica de ellos. Ésa era la propuesta de Oswald de Andrade. Basándose en la ecuación hamletiana de to be or not to be, Ser o no Ser, y tomando como referencia la existencia de los indios Tupís brasileños, él decía: tu-pí or not tu bi, that is the cuestion... Es una lógica contra otra... La poesía concreta brasileña en 1950 absorbe esa contradicción planteada por Oswald de Andrade y la proyecta a nivel internacional, general. Cae también dentro del marco latinoamericano de habla española, y hay muchos poetas influidos por ella, incluso Octavio Paz, Blanco está escrito a la luz de la Poesía Concreta brasileña. 


\section{EDUARDO AGUILAR}

Son gente que recupera para América Latina el legado de las vanguardias históricas y le dan una redimensión a partir de acá... Es muy importante eso, la década del 50... Por lo mismo digo: ya no somos tan desprevenidos cuando hubo movimientos integrales que funcionaron, a mitad de siglo, como ése. Digo hubo, porque ahora es otra cosa: nuestra diferencia ya no está evidenciada.

El modernismo hispanoamericano que estaba, con Darío, entre el siglo pasado y éste, todavía era un movimiento teóricamente insuficiente. Pero estos otros tipos, los brasileños, son teóricamente competentes.

Errar y La vida mantis son los títulos de los otros dos libros tuyos que componen el volumen al cual nos estamos refiriendo, ahora dime: ipor qué el nivel de las aguas que se besan es medio verdadero?

Bueno, el título del libro parte de un enfrentamiento de dos lógicas, veamos: una es la lógica racional que plantea un nivel medio verdadero -casi aristotélico. Es un planteo racional tomado de un mojón que vi a la salida de la Catedral, la primera vez que entré a la Catedral Metropolitana. Yo estaba parado esperando para cruzar la çalle cuando me di vuelta y vi una inscripción que decía: Nivel medio verdadero de las aguas del Lago de Texcoco, ciento no sé cuántos metros... Pensé esto mide la profundidad, el nivel medio verdadero..., porque lo otro estaba como borrado..., y me dije, parece un ready-made, lo tengo que usar... Y esperé como quince años para usarlo, no sabía dónde ponerlo...

Eso era una lógica - la lógica del nivel medio verdadero-que ahorita, como la lógica de la Verdad del Método (entre comillas), casi podría ser enumerada o nombrada por Aristóteles.

Ahora, las aguas que se besan, ese es un punto imposible; es el punto del imposible porque no hay un momento en que las aguas se besan. Porque las aguas que se pueden besar son las del río que van a dar a la mar, como dice Manrique. No hay un punto donde esas aguas se besan. Es decir, se mezclan, pero no hay un momento del beso de las aguas, no existe. El enfrentamiento de las dos lógicas es lo que produce el choque en el mismo título del libro.

Como está planteado en la sintaxis parecería que existe una consecuencia lógica en la segunda parte del título, pero no. Las aguas que se besan no pueden tener un nivel medio verdadero, es decir, el título 


\section{ENTREVISTA A EDUARDO MILÁN}

empieza de una manera lógica y por la mitad se corta, y sigue una conclusión irracional. Es un título que intenta señalar como desestructurar la imposibilidad. Porque iqué ocurre con la poesía? Si uno toma las aguas que se besan como metáfora, que sería el territorio de la poesía, funciona. Decir las aguas que se besan, es pronunciar una metáfora como cualquier otra; por decir: las aguas que se acercan o que se tocan o que se confunden...; ahora, besarse es una actividad que pertenece al terreno de lo humano. Humanizar las aguas ahí, en el acercamiento, pertenece al terreno metafórico. Si uno enfrenta las dos frases sucede que, primero: la poesía tiene una lógica diferente; segundo, el nivel medio no es tal, no es tan medio ni tan verdadero; porque si continúa un título iniciado con una lógica distinta sin que sea descubierto el conflicto, entonces, es mentira. Eso es lo que yo trato de decir en el título: nivel medio, a nivel sintáctico, por un lado. Ahora, por otro lado, existe la trampa ¿cuál es el nivel medio verdadero de las aguas que se besan? Desde el punto de vista de la poesía es el nivel de lo humano, porque el hombre lo que ha perdido, desde este punto de vista, desde mi punto de vista, es el nivel medio. Es decir, cuando - $\mathrm{y}$ ahí viene de nuevo la usurpación-, en el Renacimiento, el hombre se coloca como centro se desestabiliza en relación con su medio, baja de escala, y también rebaja de escala a la divinidad. Es decir Dios queda para abajo, el hombre queda para abajo y el animal sigue soportando el peso en esa lógica de abajo hacia arriba que hemos planteado siempre, ino?, del hombre como escala media.

Ahora, ése es el intento de decir: éste es el nivel humano entre la lógica del método y lo imposible. Ahí de alguna manera está constituido lo humano. Ése creo que es el punto que habría que recuperar. Ese nivel medio. Es decir, el hombre no puede ser centro del mundo.

Eso es lo que, de alguna manera, estoy planteando; porque produce lógicas como ésta, como la del título, que solamente son válidas en el terreno de la poesía.

Planteado de otra manera, creo que el libro, su eficacia, está en señalar que todo ocurre fuera de ahí, que el problema no está tanto digamos así, en el libro sino que está fuera. Es un libro que remite al mundo, no se remite a sí mismo.

Te haré un comentario que precisa el lugar de donde tomaste el título para tu libro. El mojón que mide el nivel de las aguas del lago de Texcoco 


\section{EDUARDO AGUILAR}

está precisamente frente al edificio del Monte Piedad, eso dice mucho también.

Y está al lado de la Catedral...

...y al lado de la Catedral, en efecto.

Al lado de la Catedral, es decir, el nivel medio verdadero, el método racional, está al lado de la representación o de la casa o del edificio que de alguna manera alberga dentro de lo que es México, a la Divinidad o lo que debería de ser la Divinidad. Está al lado.

¿Del Errar, o del error, y de La vida mantis, cuáles son las aguas que se besan?

El errar es la conciencia. Errar, en la otra acepción, es pecar. Es decir, hay una dimensión religiosa, que ya arranca desde ahí, en la poesía que hago. Reconocer el error para el método racional, desde el punto de vista de la mentalidad positiva que el ser humano occidental actual tiene, es un acto de reconocimiento difícil, sobre todo planteado desde el punto de vista poético.

54 Errar es el único concepto válido dentro de un no lugar. Porque si el no lugar es real, el no lugar del arte o de la poesía, en un mundo que no es el nuestro lo único que nos corresponde es errar; errar y errar, porque no podemos acertar en un hábitat o en un medio que no nos pertenece. Ahí el errar y el error se juntan porque estamos fuera de lugar, digamos así. Te remito a lo anterior: perdimos el medio, si no estamos en el medio sólo podemos errar en el doble sentido de la palabra. Porque el medio no es nuestro y la poesía es un movimiento extraño dentro del mundo, por eso paso de la conciencia del error a La vida mantis -que quiere decir la vida por adivinación-; para acertar uno sólo puede moverse por adivinación, oracularmente.

\section{¿Por qué España?}

Mira, España por lo siguiente: la poesía no tiene lugar. Por lo tanto no tiene mercado. La poesía latinoamericana no se lee. Latinoamérica 


\section{ENTREVISTA A EDUARDO MILÁN}

es un Continente donde la lectura está prácticamente abolida o reducida a su mínima expresión. La gente lee, creo, para no perder el lenguaje, para no perder el habla, pero lee cualquier cosa. Porque en este mundo impera el dominio de la comunicación mínima. El dominio de la comunicación utilitaria, que no tiene nada que ver con la poesía. Porque la poesía no es comunicación utilitaria. En ese sentido, en el sentido de la comunicación, la poesía es completamente inútil porque no puede resolver problemas cotidianos.

Nosotros vivimos el habla en el nivel de la cotidianidad. Ahora, ése es muy especialmente el nivel de Latinoamérica. Que por supuesto tiene connotaciones sociales, políticas, económicas, y de lo que quieras hablar, ¿no? Ahora, ése es el nivel; plantear un libro en España es como decir: mira, América Latina todavía se resiste a la comunicación utilitaria, de determinada manera.

Es el planteo de la poesía, y ahí englobamos un segundo paso dentro de la lógica del no lugar, que es: la poesía como un acto de resistencia dentro de un no lugar. Así, topológicamente considerado, es un acto que ocurre en América Latina; luego, dentro de un no lugar que es el poético.

Tu país -Unuguay - ha nutrido a algunas de las mejores tradiciones de poetas de incalculable valor, Lautréamont, por ejemplo, de quien parte una de esas tradiciones, ¿A qué Orden, con mayúscula, atribuyes dicho fenómeno?

Lautréamont influye a través de Los cantos de maldoror, (1890) que son un verdadero ataque, un ataque directo contra la sociedad y contra el hombre moderno, cuando irrumpe el hombre técnico. Están escritos, efectivamente por un nacido en Uruguay - Isidore Ducasse- de padres franceses, que se va a los 17 años a Francia y 10 años después muere.

Es enarbolado como bandera por el surrealismo junto con Rimbaud, y como bandera de libertad, como bandera de denuncia del hombre técnico. El otro poeta famoso que Uruguay da al mundo es Jules Laforgue. Es curioso, digo da al mundo porque hay un monumento, que es un barquito, en una plaza uruguaya que dice: "a los tres poetas que Uruguay dio a Francia", Lautréamont, Jules Laforgue y Supervielle, y es un barquito... Sí, el Uruguay es consciente de que da, dio poetas, hizo nacer en su tierra poetas para exportación. 


\section{EDUARDO AGUILAR}

Jules Laforgue, que también murió antes de los 30 años, nacido en Uruguay y con una peripecia semejante a Lautréamont, fue el poeta que más influyó en Ezra Pound y en T.S. Eliot, que son dos de los más grandes poetas de este siglo. Es decir, cómo es posible que Uruguay, que es considerado dentro de América Latina como uno de los países más "cultos" en el sentido cartesiano, más lógicos, más aristotélicos, sistemáticos, con un territorio de $70,000 \mathrm{Km}$ cuadrados y una población entre dos y tres millones de habitantes en la actualidad (que no ha variado mucho porcentualmente desde fines del siglo XIX), haya podido dar dos poetas de ese tamaño. A mí me parece algo muy raro, y me parece que efectivamente el nacimiento de esos dos poetas ahí señala a Uruguay como una fuente de no lugar.

Entonces, Milán ¿qué significa ser poeta, uruguayo, residente en el México de ahora?

Bueno, para mí..., mira, yo vine a México porque leí un libro que decía, Vine a Comala porque me dijeron que aquí vivía mi padre, un tal Pedro Páramo... Yo vine a México atraído por Pedro Páramo. El México que a mí interesa es ése México mítico de Pedro Páramo, que considero una de las obras más grandes de la literatura de este siglo.

Ahora, ese México, que logra coexistir con el lenguaje de la vida y de la muerte y no intenta privilegiar ninguno, que vive en la aceptación de esa coexistencia terrible, es el México mítico que a mí me atrae, esa fuerza que viene de ahí..., es la que a mí me hizo venir a México.

Yo no vine a México por ninguna otra razón. En todo caso si vine a México fue huyendo de la racionalidad implacable, o huyendo de un mundo que sólo me decía que lo único que se podía hacer era racionalizarlo todo. Vine buscando un México mítico y fue el México que realmente encontré. $Y$ es con el México que me llevo mejor; es con ese México mítico, y no con un México turístico-mítico.

Con ese México volcánico, con el México magnético. Con el México del valle, ¿no? Aunque sea el valle de lágrimas. Con ése yo me llevo bien.

Se me quedó muy grabado lo del barquito, ¿cómo viniste tú? 
Ellos salieron por agua, Lautréamont y Laforgue salieron por agua. A mi me tocó salir por aire. Pero de cualquier manera lo que importa es la salida.

Creo que lo que importa en el cambio de Lautréamont y de Laforgue fue que pasaron de la semirracionalidad implacable a la totalidad racional implacable que es Francia. Cambiaron de intensidad racional y sucumbieron.

Yo creo que la intención para mí era justamente buscar el extremo opuesto de lo que pudiera ser la racionalidad uruguaya -imperante desde un punto de vista educativo- pero que a nivel mítico estaba señalando un lugar como México. Porque Uruguay es un país surtidor de nómadas, o un país que topológicamente está estructurado como no lugar o como lugar intermedio... Históricamente es un país creado entre Brasil y Argentina para frenar el enfrentamiento entre esos dos países; es un país puesto en el medio. Está en el medio, no te olvides de eso.

Está en el medio, y es un país que de alguna manera es un no lugar, porque no responde a nada. Es un país que tenía escasos indígenas, que acabó con todo y se quedó con la inmigración europea. Toda esa gente tiene un sentimiento de extrañeza. Está frente a un puerto, Montevideo, y vive en la extrañeza de estar en un lugar que no le pertenece. No conozco un uruguayo que se sienta en su lugar, profundamente.

¿Qué posibilidades abre (o cierra) Nivel medio verdadero de las aguas que se besan para el quehacer poético latinomericano, subrayo, excluyo a España?

Bueno, yo parto de una base, Errar, La vida mantis y Nivel medio verdadero de las aguas que se besan arrancan desde una propuesta ante el lenguaje que es bastante radical.

Ante el lenguaje poético, es una propuesta bastante radical, como dije, reconociendo de antemano -incluso, en el título, Errar desde el punto de vista poético- que esto se trata de un error, porque efectivamente yo parto de la base que el lenguaje está, o estaba en ese momento, viciado y vaciado; es decir, a través del lenguaje poético uno puede señalar el vaciamiento del lenguaje común o conversacional. Pero cuando el lenguaje poético mismo ya está viciado, entonces hay que denunciar el vicio en el centro. Yo no puedo denunciar el vicio a partir de una posición 


\section{EDUARDO AGUILAR}

ingenua. Entonces, el vaciamiento está asumido desde el título, esto está viciado y vaciado, hay un error aquí. Es decir, se parte de un límite. A partir del límite todo lo que se haga es ganancia.

Ahora, salir de ahí, de esa postura radical, solamente lo podía hacer por vía, digamos así, oracular, es decir, mántica. Que para los griegos significaba el nivel del poseso, del loco, del maníaco. Manía viene de mántica, que también quiere decir adivinación. Lo que significa que era gente regida por el oráculo, guiada por el oráculo. Estamos en el territorio de la sabiduría, del preconocimiento. Estamos en el territorio de los filósofos presocráticos. Estamos en el territorio de las primeras tragedias griegas; donde nos conducimos o nos orientamos según un conocimiento oculto que es la sabiduría.

Ese paso, esa vía, que es la vía mantis entre el error y el nivel medio verdadero de lo imposible, se da en mí gracias a una guía nítida en una travesía mítica que tiene dos niveles: la guía espiritual de Gina Soto y el amor de Gabriela Gutiérrez.

Ahora, claro, llego a una conclusión, que es la de ese momento, el reconocimiento o la reestructuración de algunos problemas planteados un poco más conceptualmente: el problema de la imagen, el problema del agotamiento del lenguaje, el problema de la falsa vivencia de la poesía, la poesía vivida falsamente.

En consecuencia, Eduardo, ¿qué se defiende o se salva?, ise condena algo?, ¿queda algo indemne o inerme en ese libro?

Yo creo que se enjuicia bastante: el nivel de absoluta desprotección, el nivel de desvirtuación, el nivel de desvalimiento en que está la poesía cuando toma conciencia de su no lugar, es decir, cuando el mundo ya te expulsó y te diste cuenta que te expulsó de un lugar que nunca tuviste...

Ese es el nivel que ahí se plantea. Es decir, cuando el mundo está en un problema de no lugar generalizado, de migraciones internas y eso coincide con lo poético. Entonces hay un principio de identidad ahí que empieza a funcionar y hay que denunciarlo; por eso el libro, todo el libro, está señalando que la importancia ocurre fuera de él, está en el mundo. Es decir, señala el mundo, el error de la poesía.

Reconocer un error de la poesía o buscar un medio, es decir, volver a la poesía como mediadora es reconocer que el mundo ya no tiene lugar 


\section{ENTREVISTA A EDUARDO MILÁN}

para los poetas reales, aunque fuera un no lugar. Ya ni siquiera reconoce eso. Y no lo reconoce por el problema de la desvirtuación llevada a su última consecuencia: el intento de restitución del arte a lo social. Es decir, cuando la sociedad intenta restituirse algo que nunca tuvo. Significa entonces que está todo mal, para la sociedad y para el arte, digamos. Hay que denunciar esa posición del arte, y la sociedad queda denunciada automáticamente. Pienso que esa denuncia es clara en el libro.

Lo que intento rescatar es el nivel de lo poético como verdadero, en el sentido de apostar por una resignificación del lugar del hombre. A partir del lugar, el hombre, la poesía adquiere su verdadero valor, pero la poesía no puede adquirir un valor diferente si el hombre no está en su lugar. Es decir, el no lugar de la poesía sobreviene a partir de un no lugar del hombre, y no viceversa.

El hombre no perdió lugar porque la poesía lo perdió. La poesía perdió lugar, o nunca lo tuvo, porque el hombre se desajustó. Digo, hoy nosotros no podemos, creo yo, plantear alternativas o salidas artísticas o estéticas que no refieran a una generalidad. Es como querer hacer poesía fuera de la Tierra. Si yo pienso a la poesía como un producto humano, aunque sea vehículo de otro tipo de voces, y aunque se pueda considerar a la poesía como vehículo de un habla extraña - un habla de la divinidad, un Don, o como se quiera plantear - tiene que pasar por el medio que es lo humano. Porque lo humano es justamente una posición de mediación entre dos órdenes; y si uno no recoloca o resignifica al hombre como mediador entre los órdenes, la poesía va a estar siempre fuera de lugar. Siempre va a estar fuera de lugar, porque antes tenía el lugar de la mediación; cuando se pone en el lugar de la no mediación o cuando quiere ser otra cosa que mediación, ahí se pierde. Yo estoy por reponer o resignificar el lugar de la mediación. Es ahí donde se da el problema para mí.

Milán, creer, sostener, aseverar que las posibilidades del lenguaje son infinitas (en el sentido de que es plástico)..., partir de ahí es no creer en nada. ¿En qué creíste para hacer la poesía que hiciste, que queda consignada en este volumen, la poesía que estás formulando, parte de la cual —ya hemos hablado- está inédita en este momento? 


\section{EDUARDO AGUILAR}

Bueno, para mí, asumir el infinito, así, en esa categoría, es salir del medio justamente. Es desvirtuar la posición media; considerar el lenguaje infinito sería considerarlo como una totalidad que está fuera del hombre. Ahora, si ese infinito no pasa por el hombre, no se puede traducir aquí. Es decir, ¿cuál es el mediador en ese infinito? Incluso si consideramos el mundo como lenguaje infinito, eso tiene que pasar por el mediador. Tiene que pasar por la mediación que es el hombre; es decir, si yo me dejo hablar como poeta por el infinito y no me considero hombre, me considero Dios. Perdí. Mi lugar tiene que ser humano siempre. Porque si no al considerarme otra cosa desvirtúo al infinito, porque el orden es ése. Nunca se puede postular al lenguaje poético, al lenguaje de las artes como infinitos a partir de lo humano. Porque no es lo humano lo que decide la categoría infinita. Si el infinito existe es porque está por encima de lo humano y se define por sí mismo. No necesita del hombre para ser definido. Se expresa a través del hombre, y se expresa para ser significado aquí, en el mundo. Y adquiere varias traducciones. Pero en esto, insisto, el problema es dónde está el mediador, dónde está el hombre ahí para que se exprese el infinito y el lenguaje como infinito; el hombre tiene que estar en su lugar. Mientras no haya ese lugar o no haya la verificación de ese lugar, habrá que seguir insistiendo en esa pérdida de lugar, desde diferentes maneras.

60 El principio es la descolocación del hombre, después viene el no lugar de la poesía. El que está descolocado primero es el hombre, los poetas no tienen la culpa, serán cómplices, pero no son los culpables.

En consecuencia con todo lo anterior que hemos hablado, Milán, ¿qué tipo de lector supondría esta poesía publicada ahora, y todo esté planteamiento que está detrás de ella?

Ahí hay un problema que es serio. Si uno ve, por ejemplo, que éste es el mundo de la ficción, el mundo donde se lee narrativa porque la historia fue negada; cuando no hay un sentido, un rumbo en la sociedad, la gente necesita identificarse con un destino que esté, aunque sea, en la ficción. Por eso se consume tanta ficción hoy en día, porque la ficción promete un destino más o menos regulado que la vida o la sociedad o el hombre mismo no se lo permiten o no lo visualizan. 


\section{ENTREVISTA A EDUARDO MILÁN}

Frente al lenguaje de la ficción claramente estipulado como sustitución de un rumbo que la sociedad ya no tiene, coincide el auge de la narrativa con un quiebre en el concepto de la historia; se sustituye, el sentido de afuera se sustituye por un sentido íntimo, particular, que es la lectura de la ficción.

En vez de vivir la historia leemos ficción, y vivimos imaginariamente una historia personal; nos identificamos con el héroe de la novela porque no podemos ser el héroe de lo social.

Es el contexto que actúa ahora cuando se lee ficción - porque no olvides que estamos en la sociedad de los medios de comunicación de masa, la sociedad de la imagen y del sonido. Es la sociedad de los actores y de los cantantes, como dice Kosik. Es decir, ahí está el sonido y la representación, la imagen, y es la televisión la que regula. Evidentemente, la lectura de ficción es una lectura secundaria, y consecuentemente, la de la poesía sería como una lectura terciaria. Es decir, la de la poesía sería una última lectura. Ahora, si la poesía no defiende ese coto especial, es decir, ese no lugar, ocurre lo que ocurre con la publicidad que asimila recursos poéticos y los utiliza para vender productos. Eso es lo contrario de una práctica original de la poesía, que es la de señalar una diferencia.

A finales del siglo pasado en Rusia los narradores realizaron una suerte de indagación histórica sobre el sentido del país ruso —que después se convierte en la Unión Soviética. Tu has dicho que la narrativa, la que hoy se lee, responde a un quiebre en la historia; no indaga, y en consecuencia sustituye a la realidad por la ficción; no indaga históricamente cuál es el sentido de esta historia que estamos viviendo ahora. ¿La poesía realiza, desde ese no lugar, alguna indagación sobre la historia?

Sí, yo creo que la tarea de la poesía es justamente resignificar, reponer los significados como un ejercicio de memoria, como un acto de resistencia contra toda evidencia. La resistencia como manifestación de valores y realidades humanos que tienden a la desaparición.

El poeta es una especie de tigre de Bengala que va quedando por ahí. Pero no puede ser autocomplaciente porque es consciente. El tigre de Bengala no es consciente y por eso tiene una dimensión conmovedora. (Digo, un poeta autocomplaciente es lo último que se puede tolerar a la especie humana. Un poeta enamorado de su poesía, un artista enamo- 


\section{EDUARDO AGUILAR}

rado de su arte, en este momento es lo último). Porque si están en vías de desaparición y se comparan con los animales que desaparecen por obra del hombre - no por ellos- entonces, nos equivocamos de nuevo. Eso ya ni siquiera se puede leer, hay que tirarlo.

Ante la disolución que causaba el poder totalitario - me refiero otra vez a la Unión Soviética y toda su secuela - se defendió la literatura, el arte, la poesía como un método de conocimiento, alternativo posiblemente, ¿qué opinas, en efecto, se le puede pedir eso a la poesía?

Yo considero a la poesía un linaje, un linaje que atraviesa distintas épocas y encarna de diferentes maneras. Es un lenguaje que transmite un conocimiento anterior, pero dentro de su momento, del momento histórico que le toca vivir. Lo vive como puede, por ejemplo: a Mayakosky le toca vivir dentro de la revolución soviética y encarar o ser víctima de varias contradicciones. A otros les toca vivir en Latinoamérica en los 90, a Baudelaire o a Rimbaud les tocó vivir el siglo XIX en Francia, a Góngora en el Barroco en España..., son distintos momentos de lo mismo. Es un conocimiento estable el que transmite la poesía. Las encarnaciones se pueden dar de diferentes maneras. Ningún poeta que ha sobrevivido ha desoído su momento, y la manifestación de lo que tiene que transmitir la debe adecuar temporalmente. Es decir, no se puede plantear temporalmente como eterno, porque eso es una traición a la poesía.

El desafío para alguien que es poeta consiste en aplicar o transmitir esa sabiduría poética en su momento y con las condiciones que tiene en ese momento. Un poeta del siglo XX no puede actuar como si fuera uno del siglo XVIII, no puede escribir dentro de aquella lógica.

La impresión que me causó tu libro cuando lo lé fue que habías llegado a un límite en él o con él.

Sí, efectivamente, hay un límite ahí.

Creo que la pregunta se sintetizaría mejor así, ¿qué viene después de esto? 


\section{ENTREVISTA A EDUARDO MILÁN}

Después del reconocimiento de lo poético, de la verificación de su no lugar, viene la asunción de esos dos niveles. Hay que escribir justamente desde un no lugar, con la conciencia de un no lugar. Es decir, antes escribía acerca de un no lugar, pero la conciencia no siempre era patente. A partir de la conciencia de un no lugar uno puede resignificar en términos de lugar. Es decir, uno puede deslindar posiciones y recuperar algo que este mundo deberá recuperar: el concepto de distancia. En este mundo no hay distancia, todo está cerca, no hay trabajo, ya no se pueden hacer viajes iniciáticos, a todo se llega demasiado rápido. Uno viaja y no se da cuenta de que viajó. El viaje no tiene importancia ya. Uno viaja y ya llegó. No hay el trabajo de las pruebas del camino. Yo creo que si uno recupera la distancia ve los lugares que debe reponer. Ve cuáles son los lugares de los cuales se movieron las cosas y en qué sentido se movieron. Eso se puede ver precisamente cuando uno recupera la distancia. Una vez más, el problema es el tiempo. Yo encontré el tiempo en México.

Me decías que llegaste por aire a un lugar que te permitió recuperar la dimensión del mito, ¿esto sería consecuente con lo que me estás diciendo?

Sí, yo creo que el hombre ya no conoce esa vía, la del mito, para hacer esa especie de viaje o para tomarse la vida como un viaje o para recuperar, justamente, la distancia. Recuperar la distancia quiere decir reconocer. Reconocer la distancia, y a partir del reconocimiento de la distancia reponerse como lugar. Si no hay distancia no hay posición y no hay identificación de órdenes. Todo está confundido en el momento de caos en que vivimos ahora. Pero de caos real. Caos quiere decir, en un sentido, indiferenciación, mezcla, desorden en el sentido de no reconocimiento o no distinción de los diversos órdenes. No quiere decir anarquía o asaltantes en todas las esquinas. No, quiere decir no reconocimiento de los órdenes que existen porque se les negó. En seguida, el hombre fue desordenándolo todo sistemáticamente hasta que llegó al desorden final, que es intentar desordenar lo que lo sostiene (que es un límite): la Tierra. Señalábamos esa paradoja, ¿cómo es posible estar parado sobre algo a lo que llamamos Madre, y pisarlo? A nivel epistemológico esa es una paradoja que el hombre tiene que resolver. 


\section{LA SEGURIDAD \\ NACIONAL \\ NORTEAMERICANA: \\ LAS RESPUESTAS \\ MEXICANAS \\ (1821-1867)* \\ Raúl Figueroa Esquer**}

\section{Introducción}

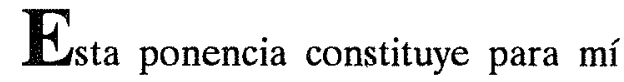
una primera aproximación al tema de la seguridad nacional; examino el punto de vista de los Estados Unidos, así como las respuestas que México, a través de este período, se planteó cada vez que los norteamericanos esgrimían razones de seguridad en su estrategia política.

Desde luego, estamos en presencia de un tema controvertido; el mismo concepto de seguridad nacional hasta hace poco tiempo no recibía atención en el medio académico mexicano. ${ }^{1}$ El término "seguridad

* Ponencia presentada en la IX Reunión de Historiadores Canadienses, Mexicanos y de los Estados Unidos, que se celebró en la Ciudad de México los días 27, 28 y 29 de octubre de 1994. La lectura de la misma tuvo lugar el día 27 de octubre en la Mesa 10: "Asuntos Nacionales y Seguridad Nacional, Canadá, Estados Unidos y México, Siglos XIX y XX".

** Instituto Tecnológico Autónomo de México.

${ }^{1}$ Sergio Aguayo y Bruce Michael Bagley, (Comps.), En búsqueda de la seguridad perdida. Aproximaciones a la seguridad nacional mexicana, México, Siglo XXI, 1994. Este libro constituye la primera aportación conjunta de estudiosos mexicanos y norteamericanos a este debate académico. 


\section{RAÚL FIGUEROA}

nacional" remitía a la ideología de los regímenes militares del cono sur latinoamericano, en especial a los sistemas establecidos en Brasil, Argentina y Chile; por esta razón no sólo se prescindía de él en el medio académico mexicano, sino que, como afïma el Dr. Lorenzo Meyer: "ni cntró fácilmente en el discurso político oficial, que buscó no asociarse en este campo con las escuelas de pensamiento desarrolladas por los regímenes militares del Cono Sur...". 2 El concepto de seguridad nacional está en proceso de redefinición. ${ }^{3}$ Actualmente existe una importante discusión entre los especialistas, ${ }^{4}$ debate que abarca una considerable gama de opiniones; algunos son partidarios de un enfoque más amplio del mismo, el cual incluye problemas del desarrollo, respeto a la democracia y soluciones adecuadas a los problemas del medio ambiente; ${ }^{5}$ otros académicos han llamado la atención sobre lo peligroso que resulta aplicarlo indistintamente a todo tipo de controversias, por considerarlas problemas de seguridad y postulan un concepto más restringido relacionado con las amenazas militares provenientes del exterior y con el cjercicio de la soberanía plena por parte de un Estado. ${ }^{6}$

Para efectos del presente trabajo utilizaré este último concepto, ${ }^{7}$ tal como lo han apreciado las autoridades encargadas de dirigir la política exterior norteamericana y también, desde luego, la forma en la cual el Estado mexicano respondió ante cada uno de los conflictos que le presentó la agenda de seguridad norteamericana.

Las respuestas mexicanas constituyen, sin duda, la parte débil en estas controversias; a menudo se nos presentan desdibujadas o poco claras.

${ }^{2}$ Lorenzo Meyer, "Prólogo", En búsqueda..., op. cit., p. 11.

${ }^{3}$ Sergio Aguayo, Bruce M. Bagley y Jeffrey Stark, "Introducción. México y Estados Unidos: en busca de la seguridad", En búsqueda..., op. cit., p. 17-40.

${ }^{4}$ Richard C. Rockweel y Richard H. Moss, "La reconceptualización de la seguridad: un comentario sobre la investigación", En búsqueda..., op. cit., p. 43-68.

5 Javier A. Elguea, "Seguridad internacional y desarrollo nacional: la búsqueda de un concepto", En búsqueda..., op. cit:; p. 76-90.

${ }^{6}$ Gene Sharp, "En torno a la definición de seguridad nacional", En búsqueda..., op. cit., p. 91-6.

${ }^{7}$ Barry Buzan, An Introduction to Strategic Studies, Military Technology and International Relations, London, Mac Millan-International Institute for Strategic Studies, 1987. 
Bien, porque dichas respuestas no alcanzaron el éxito esperado, o porque al adoptarse en momentos críticos, más parecen soluciones temporales; quizá también porque las autoridades mexicanas optaron por elegir entre el mal menor; en otras ocasiones por simple ignorancia de la existencia de las mismas.

En efecto, el éxito casi siempre coronó la estrategia norteamericana en relación con México y, por lo tanto, esta realidad ha contribuido a fomentar la creencia de que nuestra política exterior ha sido meramente defensiva o incluso errática.

Cabe señalar que, en general, los estudios de las relaciones entre México y Estados Unidos han analizado primordialmente los problemas diplomáticos entre los dos países, las relaciones económicas, los problemas migratorios, muy especialmente el de los indocumentados; últimamente han proliferado los estudios sobre el comercio y la tecnología, los problemas de contaminación y la calidad del medio ambiente, etc. Los asuntos estrictamente de seguridad sólo se han planteado cuando ha surgido un enfrentamiento militar entre ambos países o la amenaza de su inminencia.

Estoy consciente de que éste es un nuevo enfoque, el cual está por considerarse. El ensayo constituye un primer acercamiento a un tema no del todo desconocido, sino enfocado desde una metodología distinta. Desde luego, espero que la discusión que se provoque en esta mesa, me ayude a la clarificación del concepto y a la prosecución de este tipo de investigación.

Henry Kissinger en su última obra afirma: "Los norteamericanos llegaron a habitar un continente casi vacío, protegido de la amenaza de la rapiña de otras potencias por dos vastos océanos y con dos débiles países como vecinos". ${ }^{8} \mathrm{Si}$ una autoridad en política exterior norteamericana como el autor citado afirma tan tajantemente la debilidad, - sin molestarse en llamarlos por sus nombres- de México y Canadá, da a entender que Estados Unidos, por consiguiente, no ha sufrido ningún problema de seguridad en su expansionismo territorial, primero; ni después en la implantación de la dominación económica ni más tarde en su hegemonía política y militar dentro de América del Norte. Cabría,

${ }^{8}$ Henry Kissinger, Diplomacy, New York, Simon \& Schuster, 1994, p. 20. 


\section{RAÚL FIGUEROA}

entonces - como hipótesis-cuestionarse cuáles han sido las preocupaciones legítimas de seguridad norteamericana y cuáles las utilizadas únicamente como pretexto para encubrir la hegemonía dentro de la región; procedamos, pues, en un apretado recorrido histórico en búsqueda de aquellos momentos en que para los Estados Unidos el "problema mexicano" era un asunto de seguridad nacional. ${ }^{9}$

En la periodización de la historia de las relaciones México-Estados Unidos he seguido la proporcionada por dos investigadores mexicanos, quienes sin duda, hoy en día son los más autorizados sobre este temia; me refiero, desde luego, a la Dra. Josefina Zoraida Vázquezy al Dr. Lorenzo Meyer.

${ }^{9}$ Charles Austin Beard, The idea of national interest, An analytical study in American Foreign Policy. Con la colaboración de George Howard Edward Smith, New York, The MacMillan, 1934. James Watson Gantenbein, The evolution of our Latin American Policy, A documentary record, New York, Columbia University Press, 1950. Esta es una extensa compilación, el editor clasifica los documentos relacionados con nuestro país con el título "Ciertas controversias con México". Estas "controversias" se inician con los documentos relacionados con la declaración de guerra por los Estados Unidos en 1846. Samuel Flagg Bemis, The Latin-American policy of the United States, An historical interpretation, New York, Brace and Co., 1943.

${ }^{10}$ Josefina Zoraida Vazquez y Lorenzo Meyer, The United States and Mexico, Chicago-London, The University of Chicago Press, 1985. La edición original en español se titula: México frente a los Estados Unidos. Un ensayo histórico, 1776-1980, México, El Colegio de México, 1982. He utilizado la edición en inglés y a ella corresponden las citas. En esta ponencia que se refiere únicamente al Siglo XIX citaré el libro como: Vázquez, The United..., op. cit. La historiografía sobre las relaciones México-Estados Unidos con carácter global es bastante importante y su número se ha acrecentado en los últimos años. Véase entre otras las siguientes obras, las cito por el año en que aparecieron, James Morton Callahan, American Foreign Policy in Mexican relations, 1932, Reprint, New York, Cooper Square Publishers, 1967. Howard F. Cline, The United States and Mexico, Cambridge, Mass., Harvard University Press, 1961. Luis G. Zorrilla, Historia de las relaciones entre México y los Estados Unidos de América 1800-1958, 2 v, México, Porrúa, 1964. Karl M. Schmitt, Mexico and the United States, 1821-1973. Conflict and coexistence, New York, John Wiley and Sons, 1974. Peter M. Smith, Mexico: The quest of U.S. policy, New York, Foreign Policy Association, 1980. Susan Kaufman Purcell, (Ed.), 
RELACIONES ENTRE EE.UU.-MÉXICO (1821-1867)

\section{Estados Unidos y la independencia mexicana}

Las Trece colonias inglesas de América del Norte obtuvieron la emancipación de su metrópoli por medio de una sublevación y de una guerra que pronto se mostró internacionalizada, ya que los patriotas norteamericanos se vieron favorecidos por el apoyo de dos naciones europeas enemigas tradicionales de Gran Bretaña: Francia y España. El proceso de independencia mexicana es mucho más complejo; tiene varias etapas claramente diferenciadas y fue librado únicamente por los insurgentes mexicanos sin contar con la colaboración de ningún país europeo. Tampoco recibió auxilio de otras colonias españolas, ni manifestó el carácter continental que predominó en el proceso de emancipación en la América del Sur. Los representantes de los insurgentes mexicanos, quienes viajaron a los Estados Unidos en búsqueda de ayuda, no tuvieron éxito en su misión. ${ }^{11}$

La razón encubierta radicó en el hecho de que a las autoridades norteamericanas les interesaba más bien llegar a un acuerdo con España para delimitar las fronteras de Estados Unidos con la Nueva España. En efecto, después de la venta de la Luisiana por Napoléon Bonaparte a la Unión Americana en 1803, era preciso establecer un acuerdo de límites; España, en 1819 se vio en la necesidad de transigir y ceder la Florida para asegurar la demarcación de su colonia más septentrional. ${ }^{12}$

Fue hasta el momento de consumación de la independencia cuando claramente Estados Unidos se interesó por reconocer y establecer rela-

Mexico-United States relations, New York, Academy of Political Science, 1980. Richard D. Erb y Stanley R. Ross, (Eds.) United States relations with Mexico: context and content, Washington, D.C., American Enterprise Institute for Public Policy Résearch, 1981. Ernst Barkdale Ficher, Mexico and the United States. Their linked destinies, New York, Thomas Y. Crowell, 1983.

${ }^{11}$ Charles Carrol Griffin, The United States and the disnuption of the Spanish empire, 1810-1823. 1936, Reprint, New York, Octagon Books, 1968. James Johnston Auchmuty, The United States Government and Latin American Independence, 1810-1830, London, P.S. King and Son, 1937.

12 Manuel Fernández de Velasco, Las relaciones entre los Estados Unidos y España, México, UNAM, 1964. Philip C. Brooks, Diplomacy and the borderlands: The Adams-Onís Treaty of 1819, 1939, Reprint, New York, Octagon Books, 1970. 


\section{RAÚL FIGUEROA}

ciones diplomáticas con los países hispanoamericanos y muy especialmente con México, por la cercanía.

\section{Las décadas más difíciles, 1821-1848}

a) Las relaciones diplomáticas, 1821-1848

Sin duda, durante este período se recrudecieron y se mostraron nefastas las relaciones entre ambos países. De los cinco primeros ministros norteamericanos en México, cuatro fueron expulsados del país; surgió una primera ruptura de relaciones en 1836 , una segunda en 1845 que provocó la invasión norteamericana a territorio mexicano al año siguiente. ${ }^{13}$

Desde la llegada de Joel R. Poinsett se manifestó en forma muy obvia que el primordial objetivo de los Estados Unidos era apoderarse de Texas; el argumento lo basó sosteniendo que formaba parte de la Luisiana. La estancia de los primeros diplomáticos en México la caracterizaba una multitud de dificultades en su relación con las autoridades de este país. Poinsett asumió una postura abiertamente intervencionista en la política interna mexicana y por tal conducta fue expulsado a finales de 1829. Anthony Butler, su sucesor tuvo un trato difícil con las autoridades mexicanas, además de ser un especulador de tierras en Texas. Powhatan Ellis, el tercer representante, sufrió la misma suerte de sus antecesores y a finales de 1836 abandonó la ciudad de México. El gobierno de este país le hizo entrega de sus pasaportes, como protesta por el apoyo proporcionado - aunque encubierto- de las autoridades norteamericanas a los rebeldes texanos.

A partir de la estancia de Butler en México, los Estados Unidos presionaron constantemente a las diversas administraciones mexicanas y presentaron una serie de reclamaciones por parte de sus ciudadanos. No todas podían ser fundamentadas.

La permanencia del cuarto representante, Waddy Thompson y el encargado de negocios que cubrió sus ausencias, Benjamin Green se concentró en el asunto de las reclamaciones. Todo esto parecía indicar

${ }^{13}$ Carlos Bosch García, Historia de las relaciones entre México y los Estados Unidos, 1819-1848, México, UNAM, Escuela de Ciencias Políticas y Sociales, 1961. 
que los norteamericanos se propusieran establecer una barrera de humo al problema realmente grave entre ambos países, el cual radicaba en el asunto de Texas.

En resumen, el ejercicio de una diplomacia seria y responsable de parte norteamericana hacia un país como México, les pareció innecesario e improcedente. Buscaron obtener las mayores ventajas de la debilidad mexicana, así como fomentar la profunda división que existía entre los grupos rectores de México, en cuyo proceso de gestación no llegaban todavía a un acuerdo sobre la organización política del Estado.

Me interesa resaltar que fue en el campo de las relaciones diplomáticas donde tuvo lugar una respuesta de parte de México hacia los afanes expansionistas norteamericanos; esta la constituyó la polémica suscitada entre el último representante norteamericano - antes de la ruptura definitiva de relaciones-Wilson Shannon, así como por Manuel Crescencio Rejón, ministro de Relaciones Exteriores de México, durante los meses de octubre y noviembre de 1844 . En este momento se habían iniciado las negociaciones entre las autoridades de la República de Texas y las norteamericanas, con el objeto de proceder a la anexión de dicha república a la Unión Americana. Parte de los argumentos que Shannon esgrimió ante Rejón se fundamentaban en asuntos de seguridad. La anexión de Texas, afirmaba Shannon era vital para fortalecer la posición de la Luisiana; a lo que Rejón replicó que la preocupación por su seguridad llevaría "a la absorción de todo el continente [americano], y hasta del mundo entero por parte de los Estados Unidos".

\section{b) El expansionismo territorial norteamericano}

La creencia de los "padres fundadores" de la Unión Americana acerca de que su sistema político era el más perfecto sobre la tierra se basa en

${ }^{14}$ Carlos Bosch García, Material para la historia diplomática de México, México y los Estados Unidos, 1829-1848, México, UNAM, Escuela de Ciencias Políticas y Sociales, 1957, p. 458. William R. Manning, Diplomatic correspondence of the United States: Inter-American Affaires, 1831-1860, 12 v, Washington, Carnegie Edowment for International Peace, 1932-1939, Manuel Crescencio Rejón a Wilson Shannon, 21 de noviembre de 1844, VIII, 690. 


\section{RAÚL FIGUEROA}

razones históricas y teológicas ligadas a la ideología puritana. ${ }^{15}$ De ellas se van a derivar en el siglo XIX la idea de "Destino Manifiesto"; ésta se refiere a la obligación de extender los beneficios de tal sistema político a todas las regiones de la tierra; desde luego, primero a las más próximas. Paralela a la misma idea se desarrolló la de "Misión"; ésta, aparentemente menos agresiva tenía la finalidad de convencer al resto del mundo de los beneficios de la organización política y económica norteamericana. Un historiador estadounidense ha tratado de distinguir entre ambos conceptos y atribuye la parte expansionista y depredadora al primero, mientras que el segundo se lleva la altruística.

El Dr.Juan A. Ortega y Medina esclareció que ésta era "una ingeniosa, pero inoperante distinción" y aseveró que los pueblos, cuando han sufrido ya del expansionismo territorial, ya del imperialismo económico de la Gran República, difícilmente pueden distinguir los matices que diferencian a ambos conceptos. ${ }^{17}$ En éste, como en muchos otros temas no puedo extenderme en la presente ponencia.

Hubo varias respuestas mexicanas al expansionismo norteamericano, algunas las analizaré más adelante, sobre todo, las relacionadas con Texas. Existió una de carácter global, diseñada por Lucas Alamán en 1831, es el llamado "Pacto de Familia". Consistente en un proyecto de unión anfictiónica de los países latinoamericanos contra las amenazas de

72 los Estados Unidos. Alamán envió a dos comisionados mexicanos a los países de América del Sur; a Juan de Dios Cañedo y Manuel Díez de Bonilla. "Esta iniciativa... fue un fracaso, el dinamismo norteamericano obtuvo una fácil victoria sobre el estancamiento latinoamericano". ${ }^{18}$

${ }^{15}$ Juan Ortega y Medina, Destino Manifiesto. Sus razones históricas y su raiz teológica, México, Secretaría de Educación Pública, 1972.

${ }^{16}$ Frederick Merk, Manifest Destiny and Mission in American History, New York, Vintange Books, 1966. Este libro establece una polémica con el de Albert Katz Weinberg Manifest Destiny. A study of nationalist expansionism in American History, 1935, Reprint, New York, AMS Press, 1979.

${ }^{17}$ Ortega y Medina, op. cit.

${ }^{18}$ Vázquez, The United..., op. cit., p. 29-30. 
RELACIONES ENTRE EE.UU.-MÉXICO (1821-1867)

\section{c) La cuestión de Texas}

En 1819 el gobierno de España autorizó a Moisés Austin y después a su hijo Stephan para realizar una colonización con 300 familias en ese territorio. Esta concesión fue ratificada por Iturbide y después por la República Federal. El flujo de norteamericanos no cesó y ya para 1826 aparece una primera muestra del deseo por lograr la independencia que finalmente es obtenida en 1836. Este tema ha sido extensamente estudiado por varios historiadores, tanto mexicanos como norteamericanos. ${ }^{19}$ Me interesa resaltar aquí únicamente las seis respuestas mexicanas ante esta controversia.

La primera fue desde luego, lograr la ratificación del Tratado AdamsOnís por parte de los Estados Unidos y el México independiente; hecho que finalmente se alcanzó en 1832 y la ratificación del mismo tuvo lugar en $1836^{20}$

La segunda consistió en la labor llevada a cabo por el general Manuel de Mier y Terán, enviado especialmente para realizar una inspección de la colonización del territorio texano, de 1827 a 1829 . De ello resultó evidente que Texas era habitado por una población de origen norteamericano ocho veces mayor que la mexicana, así como los preparativos norteamericanos destinados a invadir Texas. Mier proponía el establecimiento de presidios; esto es, fuertes militares, la colonización del territorio por mexicanos y europeos, así como el establecimiento de aduanas. Los texanos, por su parte, estaban preocupados por las restricciones a la esclavitud que imponían las autoridades mexicanas. ${ }^{21}$

De los informes de Mier y Terán se derivó la tercera respuesta, la cual consistió en la Ley de Colonización fechada el 6 de abril de 1830,

${ }^{19}$ Vito Alessio Robles, Coahuila y Texas desde la consumación de la independencia hasta el Tratado de Paz de Guadalupe Hidalgo, 2 v., México, Antigua Librería de Robredo, 1945-1946. Eugene Campbell Barker, Mexico and Texas, 1821-1835, 1928, Reprint, New York, Russell \& Russell, 1965. Willian Campbell Binkley, The expansionist movement in Texas, 1836-1850, 1925, Reprint, New York, Da Capo Press, 1970.

${ }^{20}$ Vázquez, The United., op. cit., p. 30.

${ }^{21}$ Ibidem, p. 29. 


\section{RAÚL FIGUEROA}

expedida por Alamán. Por medio de esta ley, la colonización pasaría a ser controlada directamente por el gobierno federal de la República, y se enviarían 3000 hombres de las milicias de los estados vecinos a Texas, pero desgraciadamente dichos hombres se negaron a cooperar. También previó el envío a Texas de "familias pobres y honestas". 22

Todas estas buenas intenciones quedaron en eso. Por consiguiente, al declararse independientes los texanos en 1836, la cuarta respuesta mexicana no pudo ser otra, sino la de obligarlos por la fuerza a continuar dentro de México. A ello estuvo encaminada la expedición de Santa Anna, quien, si bien pudo someter por la fuerza a los texanos en El Álamo y en El Encinal del Perdido, fue completamente derrotado en la batalla de San Jacinto. Los texanos recibieron apoyo oficial y semi-oficial de parte del ejército, del gobierno y de la población norteamericana. Por lo anterior, el ministro mexicano en Washington, Manuel Eduardo de Gorostiza, protestó ante el gobierno estadounidense por el paso de tropas norteamericanas -comandadas por el general Gaines-a través del Río Sabina. Evidentemente esta movilización había sido ordenada por el presidente Jackson. ${ }^{23}$

La retirada del ejército mexicano no consolidó la existencia de una frontera claramente entre Texas y México. Hubo una serie de ataques y contraataques de parte del ejército mexicano, de 1836 a 1843. Esta fue

74 la quinta respuesta. San Antonio de Béjar fue recuperado y después perdido por los mexicanos, pero jamás lograron los texanos establecer el territorio por ellos dominado, más allá del Río Nueces. ${ }^{24}$

La sexta respuesta mexicana consistió en una labor de espionaje realizado de 1841 a 1845 por el cónsul de México en Nueva Orleáns, Francisco de Arrangoiz. Esta misión confidencial consistía en proporcionar informes primero, a las autoridades civiles y militares de México acerca de los movimientos del ejército norteamericano, el cual buscaba apoyar la consolidación de la República de Texas; después establecer una red de agentes entre Texas y Luisiana; y finalmente mantener al

\section{Ibidem., p. 34.}

${ }^{23}$ Ibidem, p. 36.

${ }^{24}$ Joseph Milton Nance, After San Jacinto: the Texas-Mexican frontier, 1836-1841, Austin, University of Texas Press, 1962. Joseph Milton Nance, Attack and counteratack: the Texas-Mexican frontier, 1842, Austin, University of Texas Press, 1962. 
tanto a México de los esfuerzos texanos por lograr su incorporación a la Unión Americana. Cuando el Congreso norteamericano votó por la anexión de Texas a finales de febrero de 1845, el ministro de México en Washington, Juan N. Almonte exigió como medida de protesta, sus cartas credenciales. De esta forma, México suspendió sus relaciones diplomáticas con la Unión Americana. Arrangoiz permaneció como el único agente oficial de México en los Estados Unidos de marzo a agosto de ese año. ${ }^{25}$

\section{d) La invasión norteamericana a México}

Consumada la anexión de Texas en el verano de 1845, el gobierno del presidente Polk buscó un pretexto para provocar la guerra contra México. Obviamente el problema ya no era Texas, sino la adquisición del territorio adjunto: Nuevo México y conseguir la expansión al Pacífico mediante la compra de California. Polk trató por medio del comodoro Stockton de inducir un enfrentamiento entre mexicanos y norteamericanos en el territorio en litigio, ya no entre México y Texas, sino entre los Estados Unidos y México, esto es: la franja comprendida entre el Río Nueces y el Río Bravo. Stockton fracasó en su intriga, pero fue enviado por Polk con misión similar a California. ${ }^{26}$

El fracaso de Stockton en Texas no arredró al presidente Polk, quien queriendo utilizar todos los medios a su alcance envió a un comisionado ad hoc a México con el fin de llegar a un acuerdo sobre las nuevas fronteras. El comisionado fue John Slidell, quien arribó a México en diciembre de 1845 , en momentos especialmente delicados, ya que al poco tiempo tuvo lugar un golpe de estado contra el gobierno del presidente

25 Silvia Argüello y Raúl Figueroa Esquer, El intento de México por retener Texas, México, Secretaría de Educación Pública, 1982. Soy consciente que una de las atribuciones conferidas a un cónsul es informar a su gobierno de todo movimiento que pueda afectarlo, pero en el caso específico de Francisco de Arrangoiz llevaba una misión privada y confidencial que ha sido extensamente tratada por Silvia Argüello y el autor de esta ponencia.

${ }^{26}$ Glenn W. Price, Origins of the war with Mexico: the Polk-Stockton intrigue, Austin, University of Texas Press, 1967. 


\section{RAÚL FIGUEROA}

Herrera. En enero de 1846 se instituyó el gobierno de Paredes y Arrillaga, quien por medio de su ministro de Relaciones Exteriores, Castillo y Lanzas, se negó a recibir a Slidell, éste se vio en la necesidad de abandonar el país a finales de marzo, y por lo mismo, no se llegó a ningún arreglo. $^{27}$

A principios de mayo se produjo el deseado enfrentamiento entre tropas norteamericanas y mexicanas en el territorio en litigio. Este último acto, aunado al agravio hecho a Slidell, además de las reclamaciones no satisfechas por México a ciudadanos norteamericanos, conformaron el cuerpo de la declaración de guerra, ya preparada con anterioridad. Polk únicamente agregó la frase: "ha sido derramada sangre norteamericana en territorio norteamericano". 28

Taylor invadió México por el noreste; Kearney ocupó Nuevo México y California. Scott inició una penetración cuya base fue el puerto de Veracruz y, de esta manera, se obtuvo la conquista de la ciudad de México. La invasión norteamericana constituyó prácticamente un paseo militar. México sufrió una serie de derrotas: sólo de la Batalla de la Angostura, se puede afirmar que la victoria pudo ser realizada o al menos se logró un empate. ${ }^{29}$

México sustentó un esfuerzo por llevar a cabo una guerra de corso contra embarcaciones norteamericanas, que ocasionaran daños a su comercio. Únicamente en un lugar tan distante - como el Mar Medite-

${ }^{27}$ Gobierno de México, Últimas comunicaciones entre el gobierno mexicano y el enviado extraordinario y ministro plenipotenciario nombrado por el de los Estados Unidos sobre la cuestión de Texas y admisión de dicho agente, México, Imprenta de Cumplido, 1846.

${ }^{28}$ Vázquez, The United..., op. cit., p. 44.

${ }^{29}$ Cito a continuación la bibliografía que he consultado para el estudio de la guerra entre México y los Estados Unidos. Ramón Alcaraz, et. al., Apuntes para la historia de la guerra entre México y los Estados Unidos, México, Siglo XXI; 1972, (ed. facsimilar de la de 1848). José Maria Roa Bárcena, Recuerdos de la invasión norteamericana 1846-1848, 3 v., México, Porrúa, 1947. Seymour V. Connor y Odie B. Faulk, North America divided: The Mexican War, 1846-1848, New York, Oxford University Press, 1971. David M. Pletcher, The diplomacy of annexation: Texas, Oregon and the Mexican War, Columbia, University of Missouri Press, 1973. 
RELACIONES ENTRE EE.UU.-MÉXICO (1821-1867)

rráneo- esta tentativa alcanzó un fruto pasajero; un corsario mexicano logró la captura de una goleta norteamericana. ${ }^{30}$

Desde mi punto de vista, la más importante respuesta mexicana ante una guerra perdida lo constituye el Tratado de Paz de Guadalupe-Hidalgo. Ya no es posible repetir que la paz fue producto de las circunstancias; se fraguaba en los Estados Unidos un movimiento muy importante destinado a la absorción de todo México. ${ }^{31}$

Fue un esfuerzo llevado a cabo por la "administración queretana" dirigida por el presidente Manuel de la Peña y Peña y de los comisionados de paz, Luis G. Cuevas, Bernardo Couto y Luis Atristáin, quienes negociaron con el enviado norteamericano, Nicholas P. Trist, el Tratado que pondría fin a la guerra. Esta negociación constituyó un esfuerzo inmenso, tanto por preservar la mayor parte del territorio posible para México, como por el apremio de velar por la suerte de los mexicanos que pasaban a ser extranjeros en su propia tierra. Los negociadores consiguieron preservar Baja California y que ésta continuara comunicada por tierra con Sonora; se ofrecieron garantías a los mexicanos que vivían en los territorios cedidos -mismas que después fueron quebrantadas por las autoridades norteamericanas - y se vieron en la necesidad de aceptar una indemnización, especie de venta forzosa por el inmenso territorio perdido. ${ }^{32}$

Justo Sierra ha señalado que el Tratado de Guadalupe-Hidalgo fue muy doloroso, pero no ignominioso. Cabría hacer la comparación de éste con otros tratados referentes a la historia del propio siglo XIX, para concluir reconociendo que los comisionados mexicanos realizaron el trabajo más decoroso posible. ${ }^{33}$

${ }^{30}$ Raúl Figueroa Esquer, La guerra de corso de México durante la invasión norteamericana, 1846-1848, (en curso de publicación).

${ }^{31}$ John O. Fuller, The movement for the acquisition of all Mexico, 1846-1848, 1936, Reprint, New York, Da Cappo Press, 1969.

${ }^{32}$ Raúl Figueroa Esquer, España ante la guerra entre México y los Estados Unidos. Madrid, Universidad Complutense de Madrid, 1987. v. III, El Tratado de Paz de Guadalupe-Hidalgo, pp. 786-852. (Tesis inédita).- Richard Griswold del Castillo, The Treaty of Guadalupe Hidalgo. A legacy of conflict, Norman, University of Oklahoma Press, 1990. Alejandro Sobarzo, Deber y conciencia. Nicolás Trist, el negociador norteamericano en la guerra del 47, México, Diana, 1990.

${ }^{33}$ Justo Sierra, Evolución politica del pueblo mexicano, México, UNAM, 1957, p. 249. 


\section{RAÚL FIGUEROA}

\section{3) La etapa de transición, 1848-1867}

Durante esta etapa, los Eștados Unidos no abandonaban del todo sus afanes expansionistas sobre México; además ambos países enfrentaron el desafío de sendas guerras civiles. En México tuvo lugar la "Guerra de Reforma" de 1858 a 1861, seguida casi — sin solución de continuidadpor la invasión francesa y la lucha republicana contra el imperio de Maximiliano, hasta que éste fue derrotado en 1867.Los Estados Unidos, por su parte, estuvieron envueltos en la "Guerra Civil" de 1861 a 1865.

Además de los numerosos problemas fronterizos, producto de las distintas interpretaciones del Tratado de Guadalupe-Hidalgo, los hechos más importantes de 1850 a 1856 los constituyen la serie de expediciones filibusteras urdidas por ciudadanos norteamericanos contra México. Esta época ha sido conocida como "la edad de oro del filibusterismo angloamericano". La más notable de dichas expediciones es la que encabezó Willian Walker, quien pretendía apoderarse de Baja California y de Sonora. ${ }^{34}$

Este último Estado también fue objeto de la codicia del conde francés Gaston Rousset de Boulbon, quien logró conformar dos expediciones cuyos miembros fueron reclutados en San Francisco durante 1852 y 1853 hasta que finalmente fue capturado y fusilado. La última incursión filibustera también contra Sonora la acaudilló Henry A. Crabb que terminó derrotada por el general Pesqueira en $1856 .{ }^{35}$ Ante las expediciones filibusteras la respuesta mexicana fue la única posible: repeler la fuerza con la fuerza.

La última tarascada del "Destino Manifiesto" fue el Tratado de la Mesilla, la llamada "Compra de Gadsen" por los norteamericanos. Para la adquisición de este valle de más de $75,000 \mathrm{~km}^{2}$, los Estados Unidos esgrimieron razones de seguridad: la construcción de un ferrocarril. Santa Anna, en su última administración no tuvo otra alternativa que

${ }^{34}$ William O. Scroggs, Filibusters and financiers: the story of Willian Walker and his associates, 1916, Reprint, New York, Russell \& Russell, 1969.

${ }^{35}$ Vázquez, The United..., op. cit., p. 55-62. 


\section{RELACIONES ENTRE EE.UU.-MÉXICO (1821-1867)}

plegarse al deseo estadounidense, tal vez temeroso de una nueva invasión a México; el territorio fue cedido por medio de una venta. ${ }^{36}$

Durante la guerra de reforma se manifestaron otra vez los apetitos de los norteamericanos por adquirir más territorio del norte de México. La presidencia de Buchanan se presentó con un claro deseo expansionista; quiso aprovechar la situación de guerra civil en México y por medio de su ministro, John Forsyth, presentó una oferta de compra de Baja California, partes de Sonora y Chihuahua a Félix Zuloaga, presidente de facto; propuesta que le fue denegada.

Ante esto, Forsyth propuso romper con el gobierno conservador con objeto de que Estados Unidos reconociera al gobierno de Benito Juárez, presidente de jure; lo anterior se llevó a cabo con la aprobación de Buchanan. Este envió a Robert McLane ante el gobierno liberal en Veracruz, quien firmó con Melchor Ocampo, ministro de Relaciones Exteriores, el famoso Tratado McLane-Ocampo; lo estipulado en él ha sido dramatizado hasta la obsesión por la historiografía conservadora mexicana. Patricia Galena ha esclarecido el contenido del mismo y lo ha presentado como lo que en realidad es: un tratado de tránsito; peligroso, desde luego, para la soberanía de México, ${ }^{37}$ aunque estaría por hacerse un estudio comparativo con otros tratados de tránsito internacionales para apreciarlo en su justa dimensión. De cualquier forma, el Tratado no fue aprobado por el Senado de los Estados Unidos, como afirma la Dra. Vázquez, "los senadores norteños consideraron el tratado como un esfuerzo sureño por incrementar su zona de influencia. La soberanía mexicana fue salvada, pero fortuitamente". 38

${ }^{36}$ Paul M. Garber, The Gadsen Treaty, Gloucester, Mass., Peter Smith, 1959.

37 "Larga ha sido la discusión e interminable será la disputa de los mexicanos en torno al Tratado McLane-Ocampo; pero es indudable que visto a la luz de la época, bajo las circustancias en que se dio y ante la presión norteamericana y por todos los antecedentes del mismo, el convenio merece ser entendido. Ante lo que se pretendía, se daba lo menos. No obstante, es evidente que el Tratado ponía en grave riesgo la soberanía de México". Patricia Galeana, México y el Mundo, Historia de sus relaciones exteriores, t. III, México, Senado de la República, 1990, p. 110.

${ }^{38}$ Vázquez, The United..., op. cit., p. 68. 


\section{RAÚL FIGUEROA}

El rechazo del tratado influyó también para que el gobierno de Juárez no recibiera ningún apoyo económico de parte de los Estados Unidos, pero aun sin dicha ayuda pudo imponerse al gobierno conservador; de esta manera finalizó la guerra de reforma en enero de 1861.

Al estallar la guerra civil norteamericana, el gobierno mexicano fue objeto de un coqueteo tanto de los Estados Confederados que enviaron un agente a México, John T. Pickett, como de la Unión que nombró a Thomas Corwin, como ministro. El gobierno liberal, obviamente se sentía identificado con la causa de la Unión, su ideología lo ligaba claramente al Partido Republicano; la Confederación significaba la esclavitud y el expansionismo territorial y ambos, combinados, habían jugado un papel fundamental en la pérdida de Texas; pero no podía desconocer la existencia de la frontera al norte con los Estados Confederados.

Pickett tuvo una misión azarosa en México; cometió todo género de indiscreciones; ofendió la dignidad de este país; provocó un escándalo al enfrentarse a puñetazos y en público con un ciudadano norteamericano; fue hecho prisionero por las autoridades mexicanas y conminado a salir del país. Por otra parte, su correspondencia dirigida a Richmond, capital de la Confederación, fue interceptada por el correo mexicano y enviada a Corwin. ${ }^{39}$

Pero, no todo fue hostil en México a los confederados; el cacique norteño Santiago Vidáurri estableció un próspero comercio con los sudistas. Matamoros se convirtió prácticamente en un puerto de la Confederación. Esta recibió una serie de materias primas de México o europeas importadas por este país. ${ }^{40}$ Para México era obvio que un eventual triunfo de los Estados Confederados supondría un peligro para su propia seguridad, ya que ellos buscarían expandirse hacia el Sur.

Sin embargo, otro asunto aún mas grave para México que la guerra civil norteamericana surgió en el año de 1861: la intervención tripartita

${ }^{39}$ Richard Blaine McCornack, "Los Estados Confederados y México", Historia Mexicana, 4, Núm. 3, México, El Colegio de México, febrero-marzo 1957, p. 337-52.

${ }^{40}$ José Fuentes Mares, "La misión de Mr. Pickett", Historia Mexicana, 11, Núm. 4, México, El Colegio de México, abril-junio 1962, p. 389-408. Mario Cerutti, "Entre el Río Bravo y La Habana: los comerciantes en la guerra de secesión, 1861-1865". Clara E. Lida (Comp.), Una inmigración privilegiada. Comerciantes, empresarios y profesionales españoles en México en los siglos XIX y XX, Madrid, Alianza, 1994, p. 97-120. 
de Gran Bretaña, España y Francia, con el pretexto del decreto expedido por el gobierno de México referente a la suspensión del pago de la deuda exterior durante dos años. La diplomacia mexicana pudo lograr la retirada de las dos primeras potencias, pero Francia prosiguió su objetivo el cual consistía en instaurạr una monarquía en México. El ejército al mando de Lorencez sufrió una derrota al intentar tomar la ciudad de Puebla, esta victoria republicana como lo explica la Dra. Vázquez fue "la reacción del pueblo de México causada por su experiencia en la guerra contra los Estados Unidos". 41

Contra la intervención francesa - y en solitario - tuvo que enfentarse el gobierno de Juárez, pese a que hubo muestras de simpatías para la causa republicana de parte de los diplomáticos de algunos países latinoamericanos, los cuales llegaron, incluso, a demandar de William $\mathrm{H}$. Seward, secretario de Estado norteamericano, su intervención; pero la contienda interna al norte del Río Bravo les impedía tomar una decidida posición a favor de los republicanos de México. Seward se decidió por la neutralidad. $^{42}$

Don Fernando Iglesias Calderón señaló que esta situación de colocarse al margen fue muy relativa; los Estados Unidos asumieron una actitud de egoísmo durante la intervención francesa. ${ }^{43}$ Seward era un expansionista, representaba el ala derecha del Partido Republicano y no compartía el idealismo de Abraham Lincoln. El ejército francés pudo comprar parte del equipo necesario para invadir a México en puertos de la Unión y con ello realizar el segundo sitio de Puebla.

Ciertamente el gobierno norteamericano siempre reconoció como único gobierno legítimo de México al republicano. Matías Romero, el ministro de México en Washington se vio en la necesidad de llevar a cabo una diplomacia muy atenta y vigilante en esta ciudad. ${ }^{44} \mathrm{Me}$ atrevo a afirmar que si Seward no rompió con Juárez y no reconoció al imperio,

${ }^{41}$ Vázquez, The United..., op. cit., p. 69.

42 Ibidem.

${ }^{43}$ Fernando Iglesias Calderón, El egoismo Norte-americano durante la intervención francesa, México, Imprenta Económica, 1905.

${ }^{44}$ Robert Ryal Miller, "Matías Romero: Mexican Minister to the United States during the Juárez-Maximilian Era", Hispanic American Historial Review, 45, Núm. 2, Durham, University of North Carolina Press, 1965, p. 228-45. 


\section{RAÚL FIGUEROA}

fue por no renunciar a la Doctrina Monroe, principio de la política exterior estadounidense, y por la influencia de Lincoln. En público, Seward se presentaba como un republicano radical renuente a sostener el menor trato con el imperio, pero "en conversaciones privadas con diplomáticos extranjeros mostraba una tolerancia por la monarquía mexicana, por lo que permitía a los imperialistas un cierto grado de esperanza". ${ }^{45}$ En 1865 Lincoln fue asesinado y su sucesor Andrew Johnson dejó toda la política exterior en las manos de Seward.

En el declive del imperio, tuvieron los Estados Unidos un papel muy tangencial; fue mucho más importante lo que ya desde 1905 resaltó Carlos Pereyra, en la obra en la cual es coautor con Justo Sierra, Juárez, su obra y su tiempo: la suerte del imperio más que en la caída de Richmond quedó sellada con la victoria de los prusianos sobre los austriacos en Sadowa. ${ }^{46}$

En efecto, la derrota de Austria el 3 de julio de 1866, supuso la desaparición de la Confederación Germánica, la cual era dirigida por Viena; la expulsión de Austria de los asuntos alemanes y la creación por Bismarck de la Confederación del Norte de Alemania, paso previo a la unificación o, más bien, conquista prusiana del resto de Alemania.

El engrandecimiento de Prusia, creó un desequilibrio en el continente europeo en contra de Francia. Lo anterior reforzó la decisión de Napo-

82 león III de retirar el ejército expedicionario de México, si bien esta determinación ya había sido adoptada el 15 de enero de 1866 y Maximiliano tuvo conocimientos de la misma el 21 de febrero. ${ }^{47}$ La presión diplomática que Seward ejerció sobre el Ministerio de Negocios Extranjeros de Francia, exigiendo la retirada del ejército francés de México, adquirió una forma más acentuada después de lo ocurrido en Sadowa.

Por otra parte, la misma política de Maximiliano hacia los Estados Unidos había contribuido a que perdiera la "benevolencia" de Seward. Un grupo de derrotados sudistas se trasladó a México, recibió una cordial

45 Arnold Blumberg, The diplomacy of the Mexican Empire, 1863-1867, Philadelphia, American Philosophical Association, 1971, p. 79. Cita más de veinte documentos que prueban esta actitud de Seward, además véase, p. 18, 31, 34 y 76.

${ }^{46}$ Justo Sierra [y Carlos Pereyra], Juárez, su obra y su tiempo, Pról. y notas de Martín Quirarte, México, Cámara de Diputados, 1972, p. 415-80.

${ }^{47}$ Blumberg, op. cit., p. 84-5. 
recepción por parte de Maximiliano. Se elaboraron planes de colonización e incluso el imperio expidió un decreto que autorizaba una encubierta restauración de la esclavitud; esto significaba abrir las puertas de México en beneficio de los antiguos confederados y el recorrido de la "singular institución" unos cuantos grados más al Sur. ${ }^{48}$ Lo anterior provocó que la actitud de Seward se endureciera ante el imperio.

Respecto a la ayuda material, es decir, envío de armas y pertrechos a los republicanos, sucedió después de que el Sur fue vencido y de manera irregular. Algunos escritores norteamericanos han exagerado esta cooperación y casi se atribuyen el triunfo republicano sobre el imperio, como si fuera propio. 49

Poco antes de la derrota del imperio, Seward entabló comunicación con Matías Romero expresando el deseo de su gobierno en cuanto a que Maximiliano fuera bien tratado si era hecho prisionero. Romero respondió que los Estados Unidos nunca habían pedido a los franceses que trataran bien a Juárez, si hubiera sido hecho prisionero en 1864 ó $1865 .^{50}$ Pese a toda la presión diplomática europea sobre Seward, no le quedó a éste más remedio que aceptar la decisión mexicana que prosiguió después del juicio al cual fue sometido el archiduque.

Por último, un historiador norteamericano ha comprobado que fue durante esta época, pese a todas las convulsiones internas de México, cuando se inició la penetración económica de norteamericanos "especuladores, oportunistas, capitalistas y promotores, quienes inauguraron una intensa campaña para ganar concesiones y oportunidades durante los años de 1861 a $1867 . .^{51}$

${ }^{48}$ Luis Chavez Orozco, Maximiliano y la restitución de la esclavitud en México, México, Secretaría de Relaciones Exteriores, 1961.

${ }^{49}$ Robert Ryan Miller, Arms across the border: United States aid to Juarez during the French intervention in Mexico, Philadephia, American Philosophical Society, 1973.

${ }^{50}$ Thomas D. Schoonover, Dollars over dominion: the triumph of liberalism in Mexican-United States relations, 1861-1867, Baton Rouge, Louisiana State University Press, 1978.

${ }^{51}$ Ibidem, p. 252. 
NOTAS

\section{EL CONCEPTO DE PERSONA EN LA FILOSOFIA DE MAURICIO BEUCHOT Enrique Aguayo*}

\section{Introducción}

1 1. Mauricio Beuchot nació el 4 de marzo de 1950 en Torreón, Coahuila, México. Realizó estudios de filosofía en la Universidad de Friburgo, Suiza, en la Universidad Nacional Autónoma de México y se doctoró en la Universidad Iberoamericana de México. Ha enseñado filosofía en la UIA y en la Facultad de Filosofía y Letras de la UNAM. Fue investigador en el Instituto de Investigaciones Filosóficas de la UNAM. Actualmente es investigador y coordinador del Centro de Estudios Clásicos, del Instituto de Investigaciones Filológicas de la UNAM. Es investigador nacional y miembro de número de la Academia Mexicana de Historia. Ha publicado varios libros. Su actividad intelectual abarca has a el momento cuatro áreas: filosc 'ía del lenguaje, filosofía de

* Departamento Académico de Estudios Generales, ITAM. la colonia mexicana, tomismo y humanismo.

2. Dentro del tomismo, uno de los temas que trata Beuchot es la antropología filosófica, pues para él es importante reflexionar sobre el ser de la persona, ya que, día a día, las diversas crisis políticas, económicas, axiológicas..., la van desvalorizando, van atentando contra su dignidad y sus derechos. De aquí que, para nuestro autor, el filósofo, una y otra vez, debe llamar la atención de lơs demás para que no pierdan de vista la suprema dignidad del hombre. Por esto, él ha dirigido su atención a siete temas capitales, los que, a su vez, integran este trabajo y son, a saber: I. definición de persona; II. composición ontológica de la persona; III. unión de cuerpo y alma; IV. operaciones y facultades humanas; V. perfeccionamiento de la persona; VI. dignidad de la persona; y VII. derechos humanos. Añadimos una breve concle :ón. 
NOTAS

\section{Definición de persona}

Beuchot aceptala definición que propone Santo Tomás: "supuesto [o individuo: suppositum] de naturaleza racional", y la explica de la siguiente manera: el supuesto o "individuo" expresa que la persona es perfecta y unitaria de suyo, es autónoma, independiente y suficiente, en el nivel ontológico, para ser. La "naturaleza racional" significa que tiene espíritu, con dos facultades: conocimiento y voluntad, o sea, la persona "es conciente y libre y, por lo mismo, responsable".

Nuestro filósofo dice que las actividades cognoscitivas y volitivas muestran la inmaterialidad del espíritu porque sus operaciones no se reducen a las del organismo. ${ }^{2}$ En efecto, el conocimiento tiene, como dos de sus características, ser universal y reflejo. Es universal cuando el hombre forma conceptos abstractos esenciales a partir de lo singular, Vgr.: ien qué se parecen una pelota, una manzana, un disco, una llanta? En que son redondas. Redondo es un concepto universal elaborado, no por los sentidos que únicamente captan lo singular y material, sino por el intelecto

${ }^{1}$ Cfr. Beuchot, Mauricio, "La persona humana y su proyección a lo social, según Santo Tomás", p. 55 (en adelante PS); Filosofia y Derechos Humanos, p. 51 y 53 (en adelante $F D$ ). Cita a Santo Tomás, Suma Teológica, 1, 29, 3, y De unione Verbi Incarnati, a 1.

${ }^{2}$ Cfr. Beuchot, "Reflexiones en torno a las relaciones alma-cuerpo en Santo Tomás de Aquino" (en adelante RA), p. 16. que al ser inmaterial conoce las esencias, las que también son inmateriales.

El otro tipo de conocimiento es la reflexión, i.e. doblarse sobre sí mismo para conocer las propias vivencias (algo así como el examen de conciencia). Doblarse sobre sí mismo no puede realizarlo un ser puramente material, según lo muestra la experiencia diaria, pues estaría ocupando dos veces el mismo lugar, lo cual, por definición, es absurdo, ya que la materia ocupa un lugar en el espacio. En cambio, un ser espiritual, por carecer de materia, puede plegarse sobre sí mismo. Este ser es el espíritu o alma, que es inmaterial.

\section{Composición ontológica de la persona}

Beuchot considera que en la persona humana se diferencian esencia y existencia. Mas antes de explicar estos constitutivos, exponemos algunas nociones ontológicas que faciliten entender cómo es el hombre, según la idea que de él tiene Beuchot.

\section{Prenotados ontológicos}

El ser, en la filosofía tomista, está integrado, entre otros, por dos binomios de elementos: acto y potencia; y esencia y existencia. La primera pareja explica el movimiento. Acto es lo que ya existe, por tanto, es lo perfecto; potencia es lo que puede llegar a existir, en consecuencia, es lo imperfecto.

Esencia es aquello por lo que un ser es lo que es, y sin lo cual no sería. 
Existencia es estar puesto en sí e independiente de la causa. La esencia, a su vez, se da de dos modos: si existe en sí misma, se denomina sustancia; si existe en otro, se la llama accidente. La esencia sustancial es de dos tipos: simple y compuesta. Esta última es la materia más la forma. La materia se relaciona con la potencia y la forma con el acto. Ahora apliquemos todo esto al concepto de hombre de nuestro autor.

\section{El compuesto humano}

La esencia humana la integran dos elementos: la materia o cuerpo y la forma o espíritu. Beuchot, defendiendo una de las interpretaciones de Santo Tomás, dice que ambas son substancias incompletas de cuya unión resulta la persona humana. ${ }^{3}$ No obstante, para él, la forma es más perfecta porque la materia es potencia, por ende, imperfecta; y la forma es acto, por tanto, perfecta. La forma o alma es más perfecta porque sigue existiendo aún después de que el cuerpo se corrompió. Así, el alma es incompleta en cuanto a su esencia, no en cuanto a su sustancialidad, porque tiene que estar unida al cuerpo para prefeccionarse obteniendo conocimiento, virtudes, etc. Pero es completa en cuanto a su existencia porque es inmortal. De aquí que la forma le confiera al hombre (y a cualquier ser finito corpóreo) su dignidad; "el hombre tiene la gran dignidad que le da el espíritu". 4

\footnotetext{
${ }^{3}$ Cfr. PS, p. 59-60; RA, p. 14-18.

${ }^{4}$ Cfr. FD, p. 53.
}

La existencia es la que actúa y manifiesta la esencia; es el acto de ser de la esencia.

Ahora bien, la esencia humana, dice nuestro pensador, no cambia. Trátese de un feto, o de un niño..., o de un anciano, la esencia humana: cuerpo y alma, siempre será la misma. Lo que varía en el hombre es, por un lado, la existencia: ${ }^{5}$ como feto, niño...; y por otro, añadamos nosotros, los accidentes: del cuerpo: tamaño, peso, volumen...; del espíritu: los diversos aspectos del conocimiento, diferentes tipos de hábitos, etc.

En virtud de que la esencia humana, desde que se unen óvulo y esperma, siempre es la misma, Beuchot dice, en primer lugar, que el aborto es un asesinato; $y$, en segundo término, el hombre siempre será sujeto de todos "sus derechos dondequiera que se encuentre". 6

\section{Unión de cuerpo y alma}

Siguiendo al doctor angélico, nuestro autor acepta que la unión del alma y cuerpo es substancial. ${ }^{7}$ En efecto, esa unión no es por algún intermediario que sirviera de "puente" entre uno y otro; tampoco es por yuxtaposición, de suerte que por estar juntos la actividad del alma afectara al cuerpo y viceversa, a la manera como un imán afecta a los metales que están cerca de él.

${ }^{5}$ Cfr. Beuchot, Mauricio, Metafisica y persona, p. 136-7 (en adelante, $M P$ ).

\footnotetext{
${ }^{6}$ Ibid., p. 136.

${ }^{7}$ Cfr. RA, p. 14
} 
NOTAS

La unión sustancial significa que alma y cuerpo, por ser substancias incompletas, se "compenetran" mutuamente: el alma impregna, sit venia verbo, al cuerpo, el que a su vez es apto para "recibir" a aquélla.

Por la unión substancial, alma y cuerpo, para los tomistas, se influyen mutuamente, como sucede, por ejemplo, con el enojo, pasión del alma, que hace que la cara se ruborice; o con la tristeza, pasión del alma, que puede provocar la muerte; o al momento en que se disfrutan placeres sensibles (corporales), la inteligencia puede estar obnubilada, como el que se "alegra" bebiendo alcohol. No obstante esa unidad substancial, Beuchot dice que el alma tiene más dignidad que el cuerpo, ya que puede existir y actuar independientemente de él. ${ }^{8}$

\section{Operaciones y facultades humanas}

La persona es, para nuestro filósofo, "una estructura dinámica" de tres niveles: "orgánico-vegetativo, sensorial y racional". El primer nivel es corporal; el segundo también radica en el cuerpo, aunque no absolutamente; y el tercero es de tipo espiritual.

Beuchot explica los tres niveles del siguiente modo: "se da la vida y los apetitos naturales, que tienden a un bien natural, por medio de la acción inmanente y transeúnte". En este ni-

${ }^{8}$ Ibid., p. 16-19. Cita a Santo Tomás, Suma Contra Gentiles, I, II, c. 57; Suma Teológica, I, 75, 3; De veritate, 26, 10. vel, sigue hablando él, se llevan a cabo las operaciones de nutrición, crecimiento y generación.

En el nivel sensorial

se da la vida cognoscitiva y apetitiva. La cognoscitiva mediante los sentidos, la imaginación y la memoria sensitiva; la apetitiva, mediante el apetito sensible, que no es todavía la voluntad, sino algo más rudimentario, ya que sólo es capaz de tender al bien sensible.

En el tercer nivel, el racional, están las facultades humanas: cognoscitiva, a saber: el entendimiento, que es conocimiento simple y unitario, y la razón, que es un conocimiento compuesto y sucesivo; y apetitiva, que es la voluntad constituida como racional y libre.

\section{Perfeccionamiento de la persona}

El ser humano, en cuanto que nada le falta para ser persona, es perfecto. Mas en cuanto que sus facultades carecen de contenido, es imperfecto. El dinamismo de la persona, de que antes se habló, consistirá, entonces, en perfeccionarse. En efecto, al hacer, el hombre tiene cuerpo y espíritu, mas a medida que vaya creciendo tendrá que ir desarrollando sus habilidades corporales y sus capacidades espirituales. Así, nadie nace sabiendo ni ejerciendo su libertad, nadie nace teniendo ya habilidades manuales para escribir o pa-

${ }^{9}$ Cfr. PS, p. 56-7; MP, p. 21.

Estudios 41, verano 1995. 
ra tocar algún instrumento musical. Por eso, Beuchot considera que "las facultades humanas son potencias (operativas) que dan acto segundo y perfectivo a la substancia, compuesto de cuerpo y alma".

Pues bien, cuando el hombre la da contenido a sus capacidades se perfecciona porque "las facultades pasan al acto en cuanto realizan sus operaciones con respecto de sus objetos". ${ }^{10}$ Por ejemplo: los ojos del niño que se está desarrollando instrauterinamente están en potencia de ver cuando nazca. $\mathrm{Al}$ salir del vientre materno, los ojos pasan de la potencia (posibilidad de ver) al acto (ver efectivamente).

Ahora bien, según nuestro filósofo, "es el conocimiento lo que mejor actualiza la forma o naturaleza del hombre y, por lo mismo, lo que mejor le conduce a su perfección". Él explica su aseveración diciendo que lo más propio del hombre es conocer, en consecuencia, cuando realiza esa operación se está perfeccionando. El tipo de conocimiento que mejor perfecciona es el "universal, que posee de manera virtual el conocimiento de los individuos". 11

Añadimos, por nuestra parte, que el conocimiento va a provocar el perfeccionamiento tanto de la voluntad como el del cuerpo. De aquélla porque, al conocer diversos bienes, el ser humano puede elegir de entre ellos el mejor. En el cuerpo, la influencia del conocimiento consiste en que el niño

\footnotetext{
${ }^{10} \mathrm{Cfr} . M P$, p. 21.

${ }^{11}$ Ibid., p. 51,54 y 56.
}

pequeño, por ejemplo, según vaya creciendo, querrá coger éste o aquel objeto, previamente conocido, aunque sea de manera incompleta, para jugar con él, llevárselo a la boca, etc.

\section{Dignidad de la persona}

Este tema incluye tres tópicos a analizar: ¿qué es la dignidad en cuanto tal?; sus aspectos; y la dignidad de la persona humana.

\section{Definición de dignidad}

La palabra "dignidad" es abstracta y significa "calidad de digno". Deriva del adjetivo latino dignus, $a$, um, que se traduce por "valioso". De aquí que la dignidad es la calidad de valioso de un ente.

El valor está insertado dentro de uno de los trascendentales o propiedades máximas del ente: el bien. Así, todo lo valioso es bueno, aunque no todo lo bueno es valioso.

El bien puede ser considerado, en nuestra opinión, de dos modos: a) suponiendo una tendencia hacia el deseo; y b) en cuanto a la perfección del ser en sí mismo. En el primer caso, el deseo proviene de una imperfección: lo que se quiere, se desea porque no se tiene. A la vez, el deseo expresa una tendencia hacia una plenitud: lo que se quiere, se desea porque el deseoso anhela ser mejor. Por tanto, el bien perfecciona, de algún modo, al ser que experimenta el deseo. Lo que se desea, se presenta como el bien por excelen- 
NOTAS

cia; por ende, este bien excelente es el valor. ${ }^{12}$

El segundo modo es considerar el bien en cuanto a las perfecciones que el ser tiene en sí mismo, independientemente de que sea o no objeto de un deseo. En este sentido Beuchot, inspirándose en Santo Tomás, define la calidad de valioso o dignidad como "una bondad que resulta del ser mismo de la cosa". ${ }^{13}$ Esa bondad, a su vez, es resultado de las cualidades que, en sí mismo, tiene el ser. Un ser es perfecto cuando tiene todas las propiedades esenciales que debe tener para ser lo que es. En consecuencia, la dignidad o calidad de valioso dimana de las perfecciones que tiene un ser en sí mismo, lo cual, a su vez, lo hace ser bueno, ontológicamente hablando, e independientemente de la posibilidad que tenga de satisfacer deseos.

\section{Aspectos de la dignidad}

Reflexionando sobre el tomismo, nuestro autor acepta que la dignidad puede dividirse en dos grupos: A) sustancial y accidental; y B) propia, subordinada, supraordinada y coordinada. ${ }^{14}$ En el primer grupo se conside-

${ }^{12}$ Cfr. Mejía E., Magdalena, "La calidad como punto de convergencia entre administración y filosofía", p. 59.

${ }^{13}$ Cfr. $F D$, p. 51 .

${ }^{14}$ Ibid., p. 54-5. Las definiciones las formulamos nosotros a partir de las explicaciones que Beuchot hace de la dignidad del hombre. ra la dignidad en cuanto al ser en sí mismo; en el segundo, se mira al ser en sus relaciones con otros seres.

\section{A) Dignidad sustancial y accidental}

Es sustancial la dignidad que dimana de la esencia del ser. Es accidental cuando el ser recibe determinaciones, que no brotan de sus cualidades específicas, que lo hacer ser mejor.

B) Dignidad propia, subordinada, supraordinada y coordinada

La dignidad propia es la del ser que no necesita de ningún otro tipo de ser para ser lo que es; es el ser que en sí mismo tiene, de una vez y para siempre, todas sus perfecciones. Es la dignidad que le compete a Dios. La dignidad subordinada es la de los seres que dependen en su existencia de un ser superior y anterior a ellos. Es el caso de las criaturas. Algunas de éstas se encuentran coordinadas entre sí y otras supraordinadas. Son supraordinadas las criaturas que son unas más perfectas que otras. V. gr.: el hombre tiene dignidad supraordinada a la dignidad de los animales, de las plantas y de las cosas; los ángeles (seres extramundanos y puramente espirituales) poseen dignidad supraordinada a la de los hombres; los felinos tienen dignidad supraordinada a los insectos, y éstos a las plantas, etc. Finalmente, la dignidad coordinada es la que se da entre iguales de la misma especie, como es el caso de los hombres, cuya dignidad es la misma, pues todos los 
individuos de la especie son "supuestos de naturaleza racional".

\section{Dignidad de la persona humana}

Del concepto de persona Beuchot infiere su dignidad, porque al ser supuesto o sustancia es "un ente perfecto y unitario de suyo, autónomo; con independencia y suficiencia ontológicas para ser". La persona es perfecta, dice él, porque posee en sí misma todas las cualidades o facultades que debe tener para ser persona: inteligencia y apetición (además de la psicomotricidad). Cabe precisar que una cosa es la facultad y otra el ejercicio de la cualidad. Así, un tipo de ser es el pensamiento y otro su acto: idea, juicio y raciocinio. En el primer aspecto, la persona posee sus facultades, más a medida que vaya creciendo irá obteniendo el conocimiento.

Amén de ser sustancia, la persona es de "naturaleza espiritual: racional y volitiva". Y, justamente, dice Beuchot, la persona es digna porque tiene espíritu. La razón de esto, al decir de él, es que el ser que está más apegado a la materia tiene menos perfecciones, en tanto que el ser que es más independiente, por lo menos en su hacer, de la materia, el espíritu, tiene más perfecciones o está más en acto, o ticne menos potencia. de aquí que Dios, al ser acto puro sin mezcla de potencia, i.e. al ser espíritu puro, es el ser más perfecto. El hombre, además, de ser criatura, está constituido de materia-potencia y espíritu-acto, por eso es menos perfecto.
La persona humana es digna en cinco aspectos: sustancialmente porque de su propio "ser espiritual brota su dignidad"; accidental que proviene de "las virtudes (hábitos-cualidades de la sustancia humana) para realizarse en plenitud"; subordinadamente porque es más digna que el resto de las criaturas finitas intramundanas; $y$ coordinadamente porque todos los hombres, en cuanto a su ser sustancial, son iguales.

El hombre no tiene dignidad en su aspecto propio, porque ha recibido el ser de Dios. En consecuencia, la causa eficiente remota de la dignidad humana es Él, pues le ha participado al hombre su inteligencia y su voluntad. La causa próxima de la dignidad del ser humano es su misma naturaleza: inteligencia y volición. 15

\section{Derechos humanos}

El fundamento de los Derechos humanos, según nuestro autor, es la misma naturaleza humana considerada desde dos perspectivas diferentes: la dignidad y la ley natural en sentido moral.

\section{La dignidad de la persona como fun-} damento de los Derechos humanos

La dignidad de la persona, dice Beuchot, "da al ser humano el derecho fundamental de realizar su finalidad, su destino. Es el derecho de alcanzar su

${ }^{15}$ Ibid., p. 53, 54-5 y 57-8. 
NOTAS

propia esencia". ${ }^{16}$ Alcanzar su propia esencia significa que el ser humano tiene derecho a perfeccionar su propio ser en los órdenes que lo constituyen: intelectual: estudiar, reflexionar, observar, analizar...; volitivo: elegir el bien que sea mejor para él; corporal: desarrollar habilidades manuales, etc. Ahora bien, como ningún hombre puede perfeccionarse, desde que se está gestando en el vientre materno, a sí mismo, tiene derecho a que otras personas (sus padres, sus tutores) le vayan dando bienes que lo irán perfeccionando paulatinamente: derecho, en primer lugar, a que viva, a que se eduque, a que se alimente, se vista, juegue...; hasta que llegue a la edad en que pueda valerse por sí mismo. Llegada esa edad, la persona sigue teniendo derechos que le permiten, ahora, vivir por sí mismo, dignamente: derecho a formar una familia, a un trabajo honesto y remunerado, a formar asociaciones lícitas, etc.

Cuando Beuchot afirma que la persona tiene derecho a realizar su finalidad, su destino, quiere decir que el ser humano tiene derecho a trazar sus propias metas y alcanzarlas. La palabra "destino" hay que entenderla como el punto de llegada de la acción humana. Así, por ejemplo, el destino de un estudiante es ser ingeniero civil. Esta profesión es su meta. Tiene derecho a estudiar en tal o cual universidad para obtener los conocimientos adecuados que le permitan realizarse en el campo propio de esa profesión.

${ }^{16}$ Ibid., p. 60.

\section{La ley natural moral como funda-} mento de los Derechos humanos

Antes de exponer esta fundamentación, nuestro filósofo precisa cómo, epistemológicamente, se llega a la noción de "clase natural", para después hablar de naturaleza humana, en la cual hállase la ley natural moral.

\section{a) Clases naturales}

El proceso de conocimiento de la naturaleza de un ente, según Beuchot, es éste: primero se lo conceptualiza, a partir de la experiencia, teniendo como base sus funciones, de manera ordinaria. De aquí, en un segundo momento, la persona forma "concepciones que van configurando conceptos, y ellos determinan el contenido y la extensión de las palabras de clases naturales". ${ }^{17}$ Las funciones y el contenido del ente son sus atributos propios. Así que cuando se los conoce, se conoce lo propio de un ser, o sea, su naturaleza. Con ello, se alcanza el conocimiento de la clase natural de las personas, que son los seres humanos, y se capta su dignidad. Algunas de estas ideas las toma Beuchot de la filosofía analítica y las aplica al tomismo de manera novedosa.

b) Ley natural en sentido moral

La ley natural moral es la que enuncia "haz el bien y evita el mal". El hombre llega al conocimiento de este

${ }^{17}$ Ibid., p. 128. 
principio, dice Beuchot, porque reflexiona sobre la naturaleza humana. Ésta la conoce el hombre por sus operaciones: en el orden del conocimiento, lo primero que conoce alguien es el ser, en seguida lo afirma de dos maneras: como existente y, entonces, conoce uno de sus aspectos: la verdad; y lo afirma, también como apetecible, con lo que descubre otra de sus características: la bondad. De aquí, dice él, "el conocimiento del bien se pone en tercer lugar, después del conocimiento del ser y del conocimiento de la verdad". El ser es conocido por la razón teórica; el bien, por la razón práctica. Por eso el movimiento de la voluntad sólo puede darse después del movimiento del conocimiento, ya que la persona primero conoce y luego quiere y se dirige hacia el bien.

Siguiendo al Aquinate, nuestro autor añade al intelecto y a la voluntad las inclinaciones naturales, en virtud de que el bien es el fin de todo lo que el hombre busca. Las inclinaciones naturales "se agrupan en tres clases: a) inclinación a la conservación propia, según la naturaleza; b) inclinación a la conservación de la especie por la procreación y educación de la prole; y c) finalmente, inclinación al bien, correspondiente a la naturaleza racional, como el vivir en sociedad". ${ }^{18}$

La ley natural moral se funda en la razón práctica porque es la que conoce el bien y mueve a la voluntad hacia su acción propia: obtener realmente el bien. "El bien, dice Beuchot apoyado

${ }^{18}$ Ibid., p. 139, 142 y 149. en Santo Tomás, es lo que todos apetecen, pues el bien tiene razón de fin; por eso, el primer principio práctico es que el bien ha de ser procurado y el mal evitado". 19

El cumplimiento de la ley natural moral está en función no de abstracciones, sino de una circunstancia concreta, ${ }^{20}$ de un momento específico en que se encuentra y vive cada quien. Esto, desde luego, no expresa que la ley natural moral sea arbitraria, ni que dependa del acuerdo entre los hombres; más bien significa que se adapta, objetivamente, a las necesidades de cada quien.

\section{Derechos humanos}

Para nuestro filósofo, los Derechos humanos se identifican con la ley natural moral porque la persona naturalmente tiende hacia el bien. Con esto, los Derechos humanos, ontológicamente hablando, se fundan en la naturaleza humana: ${ }^{21}$ razón y apetición, lo que significa que no son otorgados, desde fuera, por las personas, sino, más bien, custodiados por ellas.

\section{Conclusión}

De acuerdo con lo anterior, para este pensador, la persona humana no debe ser tratada como un objeto (un número, por ejemplo, en alguna de-

\footnotetext{
${ }^{19}$ Ibid., p. 139.

${ }^{20}$ Ibid., p. 152.

${ }^{21}$ Ibid., p. 143.
} 
NOTAS

pendencia oficial), porque es espíritu, es el ser más valioso que existe en el ambiente finito intramundano. Tiene derechos que dimanan de su ser de persona, cuyo sentido es favorecer su desarrollo y perfeccionamiento. En consecuencia, esos derechos no pueden ser violados, ni alienados. Al contrario, hay que respetarlos, custodiarlos y ayudar a los demás, en la medida de lo posible, a que puedan vivenciarlos.

\section{Bibliografía}

Beuchot, Mauricio, Filosofia y derechos humanos, 1993, México, Siglo XXI. , Metafísica y persona, 1991, México, Universidad Autónoma de Querétaro.

"La persona

humana y su proyección a lo social, según Santo Tomás", en Logos, n. 50,

94 vol. XVII, año XVII, 1989, México, ULSA.

en torno a las relaciones alma-cuerpo en Santo Tomás de Aquino", en Benítez, Laura y José A. Robles (compls.), $E l$ problema de la relación mente-cuerpo, 1993, México, UNAM.

MeJía Estañol, María Magdalena, "La calidad como punto de convergencia entre Administración y filosofía", en Logos, n. 62, vol. XII, año XXI, 1993, México, ULSA.

AGUAYo CRUZ, José Ignacio, "La filosofía del lenguaje de Mauricio Beuchot", en Logos, n. 65, vol. XXII, año XXII, 1994, México, ULSA.
Romero BARó, José María, "Lógica y ontología en la epistemología de Mauricio Beuchot", en Espíritu, vol. XL, 1991, Barcelona, España, ed. Instituto Filosófico Balmesiano. 
NOTAS

\section{EXÉGESIS DE UN POEMA} DE MALLARMÉ* Émile Noulet

A la nue accablante tu Base de basalte et de laves A même les échos esclaves Par une trompe sans vertu Quel sépulcral naufrage (tu Le sais, écume, mais y baves) Suprême une entre les épaves Abolit le mât dévêtu Ou cela que furibond faute De quelque perdition haute Tout l'abîme vain éployé

Dans le si blanc cheveu qui traîne

Avarement aura noyé

Le flanc enfant d'une sirène

* Traducción de Nora Pasternac, Centro de Lenguas-ITAM.

Nota: Con el pretexto de analizar un soneto de Mallarmé, Émile Noulet - crítico y literato francés-nos ofrece una excelente introducción a la estética del poeta hermético. Este artículo constituye una curiosidad historica: fue extraído de la revista Lettres Françaises, No 12 , abril de 1944, publicada en Buenos Aires. El subtítulo de la revista dice: "Cuadernos trimestrales de literatura francesa, editados a cargo de la revista SUR con la colaboración de los escritores franceses residentes en Francia y en el extranjero." En efecto,
[Ante la nube abrumadora silenciado

Base de basalto y de lavas

Entre los ecos esclavos

Por una trompeta sin virtud

Qué sepulcral naufragio (tú

Lo sabes, espuma, aunque burbujees)

Supremo uno entre los restos

Abolió el mástil desvestido

$\mathrm{O}$ aquello que furibundo falta

De alguna perdición alta

Todo el abismo vano desplegado

En el tan blanco cabello que cuelga

Avaramente habrá ahogado

El flanco infante de una sirena]

la publicación apareció en Buenos Aires durante la Segunda Guerra Mundial y se convirtió en uno de los órganos más importantes de los escritores franceses que se oponían a la ocupación alemana de su país. Fue dirigida por Roger Caillois, que debió permanecer en Argentina durante cinco años, pues la guerra y la ocupación de Francia lo sorprendieron en Buenos Aires mientras realizaba un ciclo de conferencias invitado precisamente por Victoria Ocampo que dirigía la revista SUR. Cuando regresó a París, se convirtió en un activo difusor de la literatura latinoamericana, a través de la colección "La Croix du Sud" 
NOTAS

El público francés no conoció este soneto, hermético si los hubo, sino mucho después de la muerte de Mallarmé, gracias a la edición que la Nouvelle Revue Française hizo de las Poésies Completes, en 1913.

Sin embargo, no estaba inédito. Había sido publicado por primera vez por la revista internacional Pan, editada por O. Julius Bierbaum, en Berlín, y ofrecía la foto del manuscrito en su número de abril-mayo de 1895 , acompañada de un dibujo del artista belga F. Khnopff. Apareció por segunda vez en la bella edición Deman (Bruselas, 1899), para la cual Mallarmé se tomó tanto trabajo durante el último año de su vida, escribiendo especialmente para esa edición su famosa bibliografía, aunque no llegó a verla aparecer. De todas maneras, el soneto data - en cuanto a su ejecución y a su elaboración - de una época en la que Mallarmé, en posesión de todos sus medios, no entrega a la publicación más que versos definitivos y no puntuados. Para traducirlo en términos claros no poseemos, pues, del auxilio de una primera versión ni del de ninguna controversia que una exégesis anterior hubiese suscitado. Es cierto que existen dos o tres variantes que se presentan en una reproducción posterior y sin garantías, en el libro de F. Calmettes,

que creó para la casa editorial Gallimard. A él se le debe en parte la notoriedad que Borges alcanzó en Europa a fines de la década de los 40 y durante las siguientes. Las aclaraciones entre corchetes me pertenecen. N.P.
Leconte de Lisle et ses amis (París, 1902). A pesar de todo señalémoslas, pues, verdaderas o falsas, son, con todo, significativas.

El verso 3 de la primera estrofa se escribe:

As même les échos esclaves[Tienes incluso los ecos esclavos]

$A s$ [tienes] no es un error del linotipista, sino de F. Calmettes mismo. Como se equivocó sobre el valor de $t u$ ["tú" y también participio pasado del verbo "taire": callar, silenciar] en el primer verso, buscó lógicamente en la misma estrofa el verbo que correspondería a ese supuesto pronombre personal; no pudo ver más que as; de eso dedujo que allí había un error de ortografía y restableció la $\$$ obligatoria. La s de Calmettes prueba que alguien al menos cayó en la trampa que Mallarmé había tendido suavemente al lector apresurado que, víctima de la ley del menor esfuerzo, fue conducido a atribuirle la misma naturaleza gramatical a los dos $t u$, ya que sobre el de la segunda estrofa no había ningún equívoco posible.

El segundo verso de la estrofa II, en el libro de Calmettes, se presenta de la manera siguiente:

Le sais écume mais y braves[Sabes que es espuma pero lo enfrentas]

Admitiendo aquí también la posibilidad de simples errores de imprenta, sigue siendo cierto que esas seudo-variantes tienen un sentido y que ese sentido, por erróneo que sea, trae consigo una enseñanza, aunque se presente como un efecto de rechazo. 
La sustitución de braves [enfrentas, desafías] en lugar de baves [burbujees, eches espumarajos, te babees, borbotees], no es contraria a la impresión superficial que causa la estrofa; desde el momento en que se trata de un naufragio y de la conciencia de perecer (evocados por las palabras sais [sabes], épave [restos de naufragio] y suprême [supremo]) se puede asociarles las nociones de resistencia y de valor, incluso inútiles, que despierta la palabra "desafiar" [braver].

Sin embargo, el error más interesante es la supresión de las comas antes y después de "espuma". Pues en la edición definitiva y revisada de Bruselas, que reproduce la de la Nouvelle Revue Française, esas dos comas son las únicas que Mallarmé conserva en este poema en el que, por otra parte, suprimió toda otra puntuación. Y la intención del escritor se percibe bien. Evidentemente ha querido que "espuma" sea tomado como un apóstrofe, y que no se fuera a cometer el error de convertir al término en la aposición del complemento como lo induce a creer el texto de Calmettes. Así Mallarmé, que prepara algunas trampillas para el distraído, se preocupa, en cambio, por socorrer a un lector más atento.

Una vez inutilizadas y desechadas esas variantes, para descifrar el poema sólo queda como guía la sintaxis. Gran cantidad de críticos muy ingeniosos admiten o suponen en sus comentarios que Mallarmé escribía mal el francés, y por ello se ven obligados a multiplicar los anacolutos, las silepsis y las elipsis, para extraer del texto una in- terpretación acorde con sus ideas preconcebidas. Pero si se parte de la opinión (que es la mía) de que el poeta no contravino jamás a las reglas exactas de la lengua, que probablemente conocía mejor que nosotros, es suficiente con seguir el poema paso a paso y a la letra, para culminar sin demasiado esfuerzo y $\sin$ trucos mágicos no ya en una "interpretación", sino modesta y solamente en una explicación.

Entonces, si hemos asistido a la gradual formación de su estética, si nos hemos habituado poco a poco a su vocabulario y a sus procedimientos, no estamos tan desprovistos de recursos al abordar este soneto que se encuentra al final de la evolución del poeta. Apoyándonos en una experiencia repetida, podemos dar con alguna certidumbre la transcripción real del poema.

Observemos en primer lugar que los cuartetos forman una sola frase sinuosa, arabesco cuyos movimientos violentos convienen a la representación de un naufragio.

Decidámonos luego, ya que la primera estrofa nopresenta ningún verbo en modo personal, a buscarle uno en la segunda [abolió: abolit] y a extraer la línea principal, dejando de lado los paréntesis impresos o mentales: "Qué sepulcral naufragio... abolió el mástil desvestido..., naufragio silenciado por una trompeta sin virtud... a la nube abrumadora".

Ahora podemos volver a los detalles y seguir el poema verso por verso. Ante la nube abrumadora silenciado... Se ve así aparecer la verdadera 
naturaleza y la relación de ese "tu" tan turbador: era simplemente la forma del participio pasado de "taire" [callar] y se refería a "naufragio" en el segundo cuarteto. Para que no nos equivocáramos, para obligarnos a un alto saludable, Mallarmé multiplicó las advertencias hasta hacer casi imposible la articulación por la sucesión difícil de las dentales te-tu; pero la simple inversión de una estrofa con la otra fue suficiente para imponer una pausa entre abrumadora y silenciado, pausà de la voz, que se vuelve sensible y normal, que hace inútil la puntuación superflua y justifica su omisión.

\section{El verso siguiente:}

Base de basalto y de lavas... que se podría poner entre dos guiones, sirve como aposición a "nube". De un efecto sensorial a la manera rimbaldiana, sus aliteraciones y la sucesión de sus diferentes $a$, completadas por las de accablante, imitan mejor que una descripción el peso negro de una nube baja.

\section{El verso:}

Entre los ecos esclavos... donde hay que admirar el bello y justo epíteto esclavos aplicado a ecos y que debe leerse a continuación del cuarto.

Por una trompeta sin virtud... No posee virtud la trompeta que debió anunciar el naufragio, gritarlo a los cuatro vientos, llenar los ecos con su sonido, iadvertir del naufragio a las nubes y al cielo! En lugar de eso, lo calló, y la triste derrota se consumó en el silencio y la ignorancia.
Qué sepulcral naufragio... he aquí el tema de los dos cuartetos y la base de la alegoría.

La presencia de los paréntesis: (tú

Lo sabes, espuma, aunque burbujees)... es la descripción concreta y moral de la espuma, único efecto y testigo del desastre; aunque su significación esté ligada al símbolo, tal vez sólo se justifica por la necesidad de las rimas difíciles en aves.

Supremo uno entre los restos... es una aposición de "rnástiles" y entonces podría escribirse también entre paréntesis o entre guiones; pero ison necesarias esas indicaciones gráficas? ya que es por demás evidente que, entre los restos, el mástil es el más alto, como lo dice el sentido latino de la palabra "supremo".

Abolió... ¿Es necesario insistir en la importancia de esa palabra en el vocabulario de Mallarmé? ¿Y recordar que la había heredado de Gérard de Nerval?

...el mástil desvestido... Desvestido de sus velas. En Salut [Salvación], Mallarmé designa con la misma metáfora la bella partida de los poetas: "La blanca preocupación de nuestra tela..."

Como los cuartetos, los dos tercetos no forman más que una sola frase tumultuosa cuyo sujeto es: Todo el abismo...

O aquello... implica una alternativa y anuncia otra hipótesis: ies un navío el que ha sido engullido sin apelación? o... Esas interrogaciones y la intención disyuntiva requieren entonces una pausa bastante larga después de "aquello". Por otra parte, el verso está 
singular y fuertemente cortado, como si se escucharan y esperaran los embates de los golpes del agua en el casco del navío en peligro. Porque "furibundo" se relaciona con "abismo", $y$ "falta" con el verso siguiente que se podría también considerar como un paréntesis dependiente a su vez de "furibundo".

falta - De alguna perdición alta... equivale a decir lo siguiente: A falta de una presa de valor, el abismo, el oceáno, furioso no habrá ahogado más que...

Todo el abismo vano desplegado... es junto con el primer verso de la estrofa siguiente : en el tan blanco cabello que cuelga, la descripción del mar desencadenado, cuya cólera, sin embargo, culmina sólo con la franja de espuma blanca en la cresta de las olas.

El flanco infante de una sirena... $\mathrm{El}$ mar embravecido, ¿qué habrá devorado? ¿Qué realidad? Ninguna. Una criatura quimérica. Ni siquiera. Un flanco... Todo el peso del cielo (primera estrofa), toda la violencia del mar (segunda y tercera estrofas), todas las fuerzas reunidas del viento y del agua han contribuido para aniquilar lo que apenas existe, menos que la forma entrevista de un mito naciente. Una vez más: poema desesperado que simboliza el sepultamiento de lo que no ha sido.

He aquí, entonces, determinado el tema preciso del soneto a partir del cual podemos inflarlo con todas las interpretaciones personales, ampliarlo a los símbolos más locos, relacionarlo con cualquier concepción místico-mágica. Su sentido primero está establecido; ofrecerá su resistencia propia a las significaciones segundas. Opondrá sus propias perspectivas puesto que vemos perfilarse detrás del soneto el sueño inmenso del poeta, la obra-síntesis que hubiera podido poner en jaque al azar, el Libro único, expresión total del mundo. Puesto que escuchamos, más patética aún, frente a la envergadura de semejante concepción, surgir la queja renovada de la impotencia creadora. 
NOTAS

\section{NOTA SOBRE SCHILLER (LA HERENCIA LIBERAL Y ROMÁNTICA)} Ignacio Díaz de la Serna*

$\mathbf{E}_{1}$ temporáneamente a la Restauración con el nombre de liberalismo no sólo fue una doctrina de la libertad política. Llegó a implicar además una voluntad casi generalizada de adherirse a las instituciones y valores que habían surgido con la Revolución francesa, así como la urgencia de manifestar una férrea oposición a la simple posibilidad de que se retrocediera a la antigua sociedad con la monarquía restaurada. La igualdad civil que reducía a la nobleza a la condición común y la exclusión de cualquier derecho de inspección clerical sobre el gobierno, fueron para la tendencia liberal conquistas tan importantes como el conjunto de libertades civiles garantizados por la Declaración de los Derechos del Hombre. Comprendido esto, no sería temerario concluir que el repudio hacia el Antiguo Régimen conllevó en todo momento una profesión de fe liberal. En otras palabras, la libertad no podía ausentarse de la sociedad mo-

* Departamento Académico de Estudios Generales, ITAM. derna sino por accidente y sólo temporalmente. Por encima del rechazo de un pasado humillante, el anhelo de libertad constituyó un pregón.de fe en el porvenir.

Dicho anhelo fue expresado también por la mayoría de las voces que formaron parte del romanticismo. Los escritores románticos, tanto alemanes como franceses, hablaron de «perfectibilidad», refiriéndose con ello al proyecto de dar a luz en esa época a un Hombre libre. De esta manera, el amplio crédito que acabó disfrutando el liberalismo se debió al hecho de que reunía en su seno, junto con la libertad, los elementos de la causa moderna: igualdad y progreso. La libertad, empero, fue sin duda el alma inspiradora de esa doctrina.

Antes de proseguir, resulta importante aclarar un punto. Actualmente en ocasiones se confunde la doctrina liberal con su variante económica. $\mathrm{Mu}$ chas veces se entiende por liberalismo la doctrina de los economistas liberales que desarrollaron Bentham, Mill, y otros. En ella se considera que la empresa y el libre mercado constituyen 
dos condiciones primordiales que favorecen el bienestar público. Es cierto que hacia 1789 la libertad también se comprendía en términos económicos. Pero lo que surgió en ese entonces fue esencialmente una doctrina de los derechos del hombre como individuo, siendo la propiedad y su libre disposición sólo uno de esos derechos, el menos absoluto de ellos, ya que fue el único que se estimó discutible. Si bien puede argumentarse en favor o en contra de la libertad económica, hay que conceder que en este aspecto el liberalismo, desde sus orígenes, consideró el interés público como medida para llevar a cabo una reglamentación de las actividades económicas. No obstante, se olvida a menudo cuál fue, en toda su amplitud, la herencia liberal, la cual no abarca exclusivamente modelos precisos de producción e intercambio, sino un estatuto general de los derechos que corresponden a todo individuo civilizado.

De hecho, la economía de mercado ha coexistido con los reglamentos que apoyan el interés público. Esto sucedió en los comienzos de la era industrial. La libertad económica no fue en el siglo XIX más que una fórmula digamos algebraica que las instituciones nunca encarnaron. Con la experiencia de nuestro siglo, muchos han querido comprobar que una de las condiciones de la sobrevivencia de las libertades civiles reside en una proporción suficientemente grande de libertad en la economía. Pero el siglo XIX mostró ya desde hace tiempo que la existencia de la libre empresa no basta por sí misma para asegurar el respeto de los derechos del hombre. En consecuencia, cuando se habla de liberalismo, es preciso tener en cuenta esa herencia espiritual en toda su extensión, como una filosofía que trata de las relaciones del individuo con el Estado, sin olvidar que la libertad política supone una doctrina de libertad moral. Schiller no difiere en este sentido al afirmar: «Cuando la Naturaleza aspire a afirmar su multiplicidad en el edificio moral de la sociedad, no rompa en manera alguna la unidad moral. La forma victoriosa se halla tan lejos de la uniformidad como del desorden. Totalidad de carácter ha de tener el pueblo digno y capaz de trocar el Estado de necesidad por el Estado de libertad. ${ }^{1}$

El liberalismo y el romanticismo, en cuanto que profesan la perfectibilidad humana, asientan como aspiración ciertos valores que deben realizarse humanamente, y cuya verosimilitud, sin embargo, no se podría fundar en la humanidad misma a la cual se le proponen como fin. Ambos tuvieron que recurrir, pues, al antiguo fundamento trascendente del Bien, aunque de forma distinta a como se había postulado desde la herencia platónica. La libertad, en efecto, mantiene una relación estrecha con el ideal. El impulso que en nosotros la afirma y dignifica es el mismo que nos transporta a una región de existencia superior en la que cesa para siempre la esclavitud frente al instinto.

${ }^{1}$ Schiller Friedrich von, La educación estética del hombre, 1968, 4a , Madrid, Espasa Calpe, Col. Austral, trad. Manuel García Morente, p. 23. 
NOTAS

Así, los dos son arrastrados por una lógica de la trascendencia, tratando de definirla al margen de la dogmática cristiana. Al referirse a la trascendencia, hablan sobre la experiencia inmediata según la cual el valor o la libertad implican una distancia respecto de la naturaleza. El recurso religioso puede subsistir, pero ya no está en el centro de sus preocupaciones respectivas. Se debaten nuevos asuntos para los cuales ese recurso, en opinión de quienes lo invocan, no es una respuesta necesaria. $\mathrm{Si}$ acaso ambos traslucen por momentos un cierto tinte de espiritualismo, es simplemente porque aceptan que las religiones antiguas y el cristianismo contribuyeron como ningún otro elemento a la educación del género humano.

«La gran dificultad advierte Schiller consiste, pues, en que la sociedad física no debe cesar un solo momento de existir en el tiempo, mientras que la sociedad moral se forma en la idea; no es lícito poner en peligro la existencia del hombre por respeto a la dignidad del hombre. Cuando el relojero tiene que componer un reloj, detiene el movimiento de las ruedas. Mas el reloj viviente del Estado no puede suspender su marcha; hay que componerlo sin pararlo, y cambiar la rueda sin interrumpir el movimiento de rotación. Precisa, pues, buscar un sólido apoyo que mantenga la continuidad social y la haga independiente del Estado natural que se trata de deshacer». ${ }^{2}$

La dignidad humana es la verdad central de una fe que comparten am-

${ }^{2} I b i d$, p. 18. bos movimientos, pues experimentaron por igual la necesidad del hombre de definirse plenamente y no tanto esa otra necesidad de encontrar una evidencia sobre la plenitud divina. ${ }^{3}$ Lo que está en juego es la superación virtualmente metafísica de la naturaleza, la cual tiene la finalidad de autorizar una exigencia humana. $\mathrm{O}$ mejor, esa exigencia es la humanidad misma. Por consiguiente, el cálculo ideal de la felicidad futura mediante el sacrificio de la situación presente corresponde por entero a lo humano y su actividad fundamentadora del progreso.

Ante la naturaleza y la noción de necesidad natural, tanto la actitud del romanticismo como la del liberalismo están constituidas de modo semejante. Existe una curiosa mezcla de adhesión y de reserva. Por encima de esta ambigüedad, tienden a salvaguardar la autonomía del hombre. Sin embargo, si el progreso no es otra cosa que el desenvolvimiento de nuestra naturaleza, se corre el peligro de concebirlo como fatal e inexorable. ¿Cómo garantizar entonces que es efectivamente progreso y no desarrollo ciego; que en él se realiza, a medida que se avanza, el proyecto del ideal? A la lógica de la trascendencia se une la convicción de que el tiempo obra en favor del hom-

${ }^{3}$ Schiller alude a la dignidad en la Carta XXIV, donde dice: «Es propio del hombre juntar en su condición lo más alto y lo más bajo; y si su dignidad estriba en distinguir estrictamente lo uno de lo otro, en cambio su felicidad consiste en suprimir hábilmente esa diferencia», Ibid, p.110. 
bre. La gran metamorfosis del mundo que trajo consigo la Revolución francesa representa la prueba triunfal de que el transcurso de la historia posee una dirección: la evolución objetiva que permite identificar lo moral con el progreso, legitimando así el presente como aliado en la causa de la libertad. Tal es lo que expresan las palabras de Melchthal cuando se conduele de su padre, quien ha quedado privado de la vista por orden del tirano que gobierna los cantones de Schwyz, Uri y Unterwald: «No verás, padre, el día de la libertad, pero si oirás sus cánticos. Cuando de Alpe en Alpe se levanten las llamas de las hogueras y se derrumben las fortalezas de la tiranía, Suiza entera irá a tu casa a darte la feliz nueva...» 4

Cuando se considera de manera general la marcha histórica de la humanidad, se constata que en ese movimiento progresivo todo ha sido imprescindible y útil. Los abusos de ayer justifican las mejoras de hoy. Dichos abusos tuvieron su tiempo útil, pero su utilidad está lejos de implicar que deban ser restituidos cuando desaparecen. Mientras sirven de algo se mantienen por sí mismos, y cuando caen, es porque su conveniencia ha terminado. No es extraño entonces que románticos y liberales hayan visto la Revolución con buenos ojos por ser un suceso que se había propuesto introducir la justicia en la sociedad, es decir, el imperio de la ley

${ }^{4}$ Guillermo Tell en Obras selectas, 1969 , Madrid, Bruguera, Col. Libro Clásico, trad. José Miguel Minguez Sender, p. 57-8. moral en las relaciones mutuas de los ciudadanos y en las del gobierno con los ciudadanos. El progreso moral y material de la civilización es irresistible, y bien puede reputársele como el destino del género humano.

Aquí se perfila un dilema entre el punto de vista ideal y el de la necesidad histórica, ya que se vislumbra una distancia entre el ideal filosófico y las circunstancias concretas. No obstante, el progreso tiene por objetivo reducir esa distancia. La pregunta que no puede evitarse es si los acontecimientos y la vida del mundo social están subordinados, como el mundo físico, a la influencia de causas externas y necesarias, o bien el hombre, mediante su pensamiento y su voluntad, se halla en condición de dirigirlos y gobernarlos.

En Schiller se plantea este dilema en los siguientes términos: «Ni abstracción ni experiencia pueden conducirnos a la fuente de donde emanan los conceptos de universalidad y necesidad... Fero basta que la conciencia del propio yo se presente; que, con la inalterable unidad de la misma, quede instaurada la ley de la unidad en cuanto para el hombre es, y en todo lo que por el hombre debe ser; en suma, en el conocimiento y en la acción»"

Aunado al tema de la libertad, surge en el interior de ambos movimientos el conflicto entre las nociones de derecho y de utilidad. La inquietud por intentar diferenciarlas estuvo en el

${ }^{5}$ La educación estética del hombre, op. cit., p.89. 
NOTAS

corazón del liberalismo y también preocupó sobremanera a la mayoría de los románticos. Por una parte, los liberales, empecinados en buscar una doctrina política positiva, exenta de postulados teológicos, se sintieron tentados por el utilitarismo de Bentham. Sin embargo, una adhesión incondicional del liberalismo a esa doctrina no dejaba de ofrecer serias dificultades. Por su parte, el romanticismo la combatió abiertamente porque repudiaba la moral del interés. Varios liberales, sobre todo franceses como Benjamin Constant y Guizot, elaboraron una crítica del utilitarismo que no habría de diferir mucho de la que los románticos emprendieron. El punto común que habríade reunirlos fue dilucidar si estaba permitido, en un momento dado, resistir a una ley en vigor invocando un derecho ideal aun en contra de la conveniencia social inmediata. El utilitarismo había iniciado la discusión al negar la validez de todo derecho ajeno a las prescripciones de la ley positiva. En fin de cuentas, liberales y románticos consideraban que el principio de utilidad despertaba en el espíritu de los hombres la esperanza de un beneficio y no el sentimiento de un deber. Más aún, creyeron que la evaluación de un beneficio es completamente arbitraria en la medida en que es la imaginación quien decide. En todo caso, ni sus errores ni caprichos pueden alterar la noción de deber. Una acción puede ser más o menos justa, pero nunca más o menos útil. $\mathrm{Si}$ un individuo perjudica a sus semejantes, viola los derechos que les corresponden. Esta es una verdad indiscutible. Quien juzgue esa violación simplemente por su utilidad, es probable que se equivoque $y$ encuentre utilidad en ella. Por consiguiente, el principio de utilidad es mucho más indefinido que el de derecho. De aquí que sea imperioso separar la idea del derecho y la noción de utilidad. La herencia kantiana conseguía, pues, extenderse en el siglo XIX.

«iCabe censurar al Estado por haber perdido de vista la dignidad de la naturaleza humana, cuando se trataba de defender su existencia?», se pregunta Schiller en la Carta $V$ de La educación estética del hombre. La idea de libertad en el transcurso de la Revolución había sido comprometida por los años del Terror. Además, románticos y liberales veían con desconfianza que una doctrina sobre la libertad nacida del Contrato social de Rousseau colocara la soberanía del individuo un peldaño por debajo de una voluntad general omnipotente, acabando por apoyar a una dictadura. La libertad encumbrada en esas alturas había engendrado lo contrario de lo que se había propuesto. Era preciso meditar entonces cómo la libertad podía ser algo más que un concepto vacío, una nueva tiranía.

Se creyó que la inclinación dictatorial de la política revolucionaria había tenido su origen en un error. El modelo de libertad desarrollado en las ciudades de la antigüedad grecolatina es el que la Revolución había retomado como modelo posible. La República total concebida por Rousseau y Robespierre ignoró una doctrina moderna de la libertad, exenta ya de la coacción 
que había caracterizado al civismo grecorromano. En efecto, dentro de la civilización moderna ya no era factible pensar siquiera en una participación cotidiana de cada ciudadano en el poder. Por el contrario, urgía diseñar una nueva sociedad donde se garantizaran el goce de derechos civiles y una independencia individual. La libertad ejercida en la antigüedad exigía limitar esos derechos y esa independencia. Lo que el siglo XIX denominó «libertad civil» fue prácticamente desconocido para los pueblos antiguos porque en ellos los individuos quedaban sometidos a una jurisdicción social casi irrestricta. Los ciudadanos que forman los Estados modernos comparten el poder sólo por la vía indirecta de la representación. De esta manera, el siglo XIX deseará la libertad entendida como libertad individual; lo que Schiller llama «libertad interior», la cual sólo la muerte puede arrebatar al hombre.

La garantía de esa libertad es la libertad política. Esta última es, en consecuencia, indispensable. A la independencia se añade la necesidad de progresar. Ambas constituyen el camino del perfeccionamiento.

Precisar esa noción de libertad condujo después a una reflexión doctrinal sobre la naturaleza de la soberanía. Aunque la Revolución había trasladado la soberanía del monarca a la nación, se estimó que el verdadero problema residía menos en decidir a quién pertenecía que en definir su extensión y sus límites. Porque reconocer en abstracto la soberanía del pueblo no incrementa en absoluto la libertad de los individuos. Cuando se acepta que la soberanía del pueblo es y deber ser ilimitada, se crea en la sociedad un poder excesivamente grande, sin importar ya cuál es la mano que lo maneja. El dominio de la sociedad sobre el individuo no puede franquear legítimamente ciertas fronteras. Hay sin duda una parte de la existencia humana que se conserva a toda costa independiente y que está fuera de cualquier competencia social. La soberanía se manifiesta, pues, de modo limitado y relativo. En el punto donde comienza la independencia de la existencia individual, se detiene la jurisdicción de esa soberanía. Aun el consentimiento de la mayoría no basta para legitimar sus actos. Cuando una autoridad rebasa dichos limites, se llame individuo o nación, se hace tan culpable como el peor de los déspotas.

Así, la idea moderna de libertad se opuso a la idea de libertad expuesta en el Contrato social, ya que en él se estipulaba la alienación de los derechos del individuo en favor de la autoridad colectiva, a cambio de la participación de cada ciudadano en el voto de la ley. Allí se aseguraba, por lo menos, que la colectividad no podría legislar contra los intereses de sus miembros porque todos constituían una voluntad general. Para el siglo XIX, los resultados del proyecto rousseauneano parecieron catastróficos. Extender a todos los rincones privados la competencia de la ley equivalía a organizar metódicamente la tiranía. El mayor de los errores había consistido en divinizar al legislador, fuese éste uno o muchos. 
NOTAS

En conclusión, ganó importancia la idea de que debía existir un ámbito donde el poder no incursionara y que la ley no invadiera, so pena de una ilegitimidad radical. Este principio se irguió como un auténtico imperativo categórico: es el acto de conciencia mediante el cual cada individuo establece su derecho inalienable. Filosóficamente, manifiesta un orden ideal que trasciende la fuerza; históricamente, ayuda a definir el grado de civilización más avanzado al que el hombre ha llegado, y cuyo desconocimiento, a partir de ese momento, significaría regresar a la barbarie. Sólo así el principio de libertad adquiere vida y puede realizarse. En Schiller, por ejemplo, el ideal de libertad entraña el estado estético. Ley de ese estado es «dar libertad por medio de la libertad». 
NOTAS

\section{JEAN GENET: COMEDIANTE Y MÁRTIR* Marcela Cinta**}

$\mathbf{L}$ nos permite en última instancia describirlo, no se predican de él como de los objetos que lo rodean: me refiero a que no puede decirse de un hombre que es inteligente de la misma manera que puede decirse de una mesa que es redonda o de una planta que tiene flores. Solamente podrá decirse lo que el hombre es, o parece ser, en la medida en que tomamos su situación concreta en-elmundo. El hombre es lo que se hace, lo que decide hacer él mismo de su existencia. Un hombre es inteligente si sus circunstancias le han prohibido todo conformismo mental. Solamente en este sentido podremos describir a Genet.

Si tomamos en cuenta, con la tradición hegeliana, que el Ser es Reconciliación, que es el estar del ser en sí mismo, "en casa", en armonía con la naturaleza, Genet nunca es, porque se nihiliza constantemente. Nunca une los opuestos en síntesis; existe en perma-

* Jean Genet, novelista, dramaturgo y poeta francés (1910-1986). Terminología del libro de Jean-Paul Sartre, Saint-Genet, Comédien et Martyr, París: Gallimard, 1952.

** Facultad de Filosofía, U.N.A.M. nente contradicción. Nunca se da la Sintesis final porque sería Plenitud. No podría ser negada. Y la estructura del hombre es precisamente lo relativo, lo no-pleno, lo no-absoluto. $\mathrm{El}$ hombre nunca es alge absoluto, su ser consiste en su hacer. Genet quiere negarse como ser-en-el-mundo pero no puede porque, a pesar suyo, está actuando. El contrario del bien no es el mal, ni el contrario de la honestidad es el robo, ni el contrario del amor es el odio. Todos estos pares de opuestos tienen un revés común que es el no-ser. Por eso nunca podremos ver a Genet como lo que él quiere: como la negación del mundo; porque a pesar de negarnos existimos.

Remontémonos al principio: Genet nace en París el 19 de diciembre de 1910 de padre desconocido. Su madre lo abandona en un orfanatorio siete meses después y nunca vuelve a saber de ella. Lo adoptan y pasa su infancia en una escuela en donde se le educa para ser santo. Pero, un día, en un juego casi de nin̄os, lo sorprenden robando. El solo hecho de llamarlo "ladrón" ya implica una muerte para él, una muerte de la honestidad como es- 
NOTAS

tructura de su ser. Sufre entonces varias metamorfosis que en última instancia harán de él, el hombre concreto, Jean Genet, que actúa en situaciones específicas.

La primera conversión de Genet es hacia el mal: decide ser el ladrón que la sociedad quiso; decide asumir la descripción que la sociedad ha hecho de él y responsabilizarse de ello. Roba y hace el mal para que los demás lo consideren malo, ladrón, criminal. De hecho, pasa una gran parte de su vida en la cárcel, adonde es llevado innumerables veces por toda clase de delitos.

Genet quiere ser santo para Ser, en todo el sentido del término. Busca una estructura que le permita fundamentar su ser, que le permita ser plenamente. Al ser descubierto en el robo, se da cuenta de que no puede ser santo en un sentido absoluto; entonces tratará de ser criminal en un sentido absoluto. Lo que Genet quiere es tener una naturaleza. Es ver cuál es su ser más que actuar. No es que quiera hacer el mal, sino que quiere ser malo. Busca fundamentar su vida en una ontología; quiere encontrar la solidez que le dé la estructura de su ser. Pero esto es imposible, puesto que la misma existencia, su simple estar-en-el-mundo, es ya la estructura de su ser y del ser de toda la realidad humana. Para poder ser malo, es necesario haber antes tomado la decisión de hacer el mal, de asumir la elección original que la sociedad le impuso. Por ello, Genet hace: para ser. Él quiere ser santo y se fuerza a llevar a cabo algo impuesto desde fuera por la sociedad: ser ladrón. Elige vivir esta dualidad: el robo y la santidad. Genet es el producto que se vuelve contra la sociedad que le impuso el mal. De ahí el título del libro de Sartre: San Genet: comediante y mártir.

Desde los quince años, Genet lleva una vida de delitos hacia la sociedad. Huye del reformatorio donde se le ha encerrado; roba; va a prisión; huye de nuevo; se enlista en el ejército y lo abandona: se le acusa de desertor; en España vive de la mendicidad y la prostitución; recorre casi toda Europa franqueando fronteras prohibidas. PeroGenet tiene una razón para hacerlo: Se trata de hacer el mal para-losotros, no para sí mismo. Por ejemplo, cuando atraviesa Alemania en 1934, siente que está viviendo entre ladrones y gente que se dedica a la maldad: Entonces no robará, pues robar ahí ya no significa para él hacer el mal. Para robar, necesita Genet estar en un país donde se obedezcan ciegamente las leyes morales: solamente así podrá causar escándalo. Genet actúa, entonces, siempre en función de y para los otros.

..."la realidad se adquiere exclusivamente por repetición o participación; todo lo que no tiene un modelo ejemplar está 'privado de sentido', es decir, carente de realidad (...) el hombre de culturas tradicionales sólo se reconoce como real en la medida en que cesa de ser él mismo (...) y se contenta con imitar y repetir los gestos de otro. En otros términos, no se reconoce como real, 
NOTAS

es decir, como 'verdaderamente él mismo', más que en la medida en que cesa precisamente de serlo."1

Ya no es él mismo: actúa con gestos, gestos que le permiten ser lo que la sociedad ha hecho de él: un ladrón, un criminal. Pero como él, interiormente, no es ni ladrón ni criminal (puesto que estos actos suyos son pura apariencia), será santo: hará el mal precisamente porque es un sacrificio hacerlo.

Hay una irrealidad en la elección de Genet: él cree que roba para hacerse ladrón, pero en realidad está robando. Ésa es su acción en el mundo y roba porque no tiene otros medios para subsistir, porque se le han negado otras posibilidades. Juega a robar, o a escribir, pero como en realidad roba y escribe, se engaña a sí mismo creyendo que es puro gesto y engaña al otro porque se muestra como él no es, como un Genet ficticio. Hace la comedia a pesar suyo. Cree haber elegido hacer el mal, rechazar el mundo, pero este rechazo es tan aparente como el mismo Genet: es sólo una comedia, un gesto.

Por ello Genet es comediante y mártir al mismo tiempo. Es mártir de su propia comedia. Y esta comedia es comedia y no lo es: lo es porque manifiesta el gesto de apariencia de Genet, pero no lo es porque, de hecho, es en-el-mundo y cumple su función de acción.

${ }^{1}$ Mircea -Eliade, El mito del eterno retorno, p. 63 cf. en Sartre, Saint-Genet..., op.cit., p. 305.
Otro punto: a pesar de haber tomado como elección original lo que la sociedad le había impuesto, Genet ejemplifica la libertad. Nos muestra nuestras posibilidades latentes: si somos honestos, de ser ladrones; si somos heterosexuales, de ser homosexuales; si somos fieles, de ser traidores; o viceversa. Nos muestra que necesariamente elegimos y asumimos la responsabilidad de la elección, de lo que somos, de lo que hemos decidido hacer. Lo que nos muestra Genet, en última instancia, es que siempre tenemos la posibilidad de ser lo contrario de lo que somos. Genet sabe que es un ser-para-los-otros y asume la responsabilidad de serlo. Al ser ladrón, asume la responsabilidad de tener dinero que es dinero-del-otro. Al ser escritor, asume la responsabilidad de tener palabras que son palabras-de-losotros y palabras-para-los-otros. Se considera responsable de sus poemas. ¿Por qué? Simplemente porque su elección original ha sido ésa: tomar los "útiles" de los otros para tener un arma con qué atacarlos. Se considera responsable de haber decidido hacer el mal y transformar así la sociedad en la que vive: la sociedad que lo mete en prisión o que lo lee, que actúa sobre Genet de la misma manera en que Genet actúa sobre ella.

La vida se le presenta como una insuficiencia, tanto en el campo del ser como en el campo del tener. Cuando vive en la escuela, todo es compartido para él. El único símbolo que adquiere de la propiedad es mediante el robo. A partir de este sentimiento de insuficiencia, su falta de ser es lo que le 


\section{NOTAS}

llevará a ser santo y su falta de tener le llevará a ser ladrón. Pero se da cuenta que no puede hacer el mal en un sentido absoluto (el ser del hombre es ser relativo); entonces hace el mal como sacrificio. Hace el mal a pesar suyo. Va hacia el robo como hacia una liberación de su ser. Esto lo lleva a su segunda conversión: a ser esteta; pero esteta solamente en el sentido en que le permite hacer el mal mediante la belleza creada, mediante la literatura: usa las palabras para hacer el mal; las considera armas de asesinato.

De lo anterior se deriva la razón por la cual Genet elige el mal como el único camino posible en su vida. $\mathrm{El}$ Mal es su ser-otro, porque es no reconocerse (como para Hegel). Genet, en realidad, no es malo. Al querer hacer el mal, actúa en contra de sí mismo. Actúa siendo otro. No se reconoce como sí mismo. Es otro que él mismo. El Mal, por eso, es ser otro que el Ser. Sería, por una parte, el ser del No-Ser, o sea, es lo que caracterizaría la falsedad, la apariencia; y, por otra parte, sería el no-ser del Ser: la negación de lo absoluto, de lo pleno, de lo definible. El Mal es la negatividad absoluta, es la falsedad. Genet se sabe falso. Si hiciera reales sus apariencias, éstas no adquirirían ser, sino que Genet perdería el suyo, caería en lo puramente imaginario para sí mismo. Pero, aunque su ser malo sea aparente, de hecho actúa haciendo el mal; roba y cometo delitos que lo llevan a prisión. Es percibido como criminal y, en tanto que es percibido, tiene un ser, un ser que se revela a través de sus acciones. Se- rán falsedades para el carácter de Genet pero son realidades en tanto que tienen una presencia para el mundo. Su presencia en el mundo es verdadera; sus gestos son apariencia. Es la constante contradicción en Genet; lo verdadero y lo falso se mezclan en to do momento, porque lo supuestamente falso tiene una verdad que es la presencia en el mundo.

La acción de Genet es el mal; es la destrucción en tanto que, al construir, nos exteriorizamos ante los seres y al destruir reabsorbemos el universo dentro de nosotros mismos. Es con este sentido de destrucción que Genet hace el mal. Construir es llevar a cabo una acción en el mundo. Es exteriorizarnos. Es crear un objeto, parte nuestra, que forme parte también del resto del mundo. Es hacer palpable nuestra acción. En cambio, destruir es lo contrario: es interiorizarnos. Es absorber al mundo dentro de nosotros mismos. Es tener un mundo puramente interno. Es también acción pero sin crear cosa alguna en la objetividad, sino creando en un nivel interior, en el nivel de la conciencia. Son los dos momentos de Genet: el de la acción objetiva - con la que hace la maldad - y el del tiempo interior, el de la santidad - que es reflexión sobre la acción, que es interpretación interior.

De todos los caminos que pueden significar el Mal, Genet elige primordialmente tres de ellos que representan su verdadera acción: el sacrificio religioso, la estética y la literatura. 
NOTAS

\section{EL SACRIFICIO RELIGIOSO}

Querer ser santo es querer lo absoluto, es querer el Ser, es querer lo pleno.

Es querer pertenecer a un mundo que nos es extraño e imposible.

Querer ser pleno, cuando la estructura de nuestro ser es precisamente el no serlo es querer lo imposible. Es querer ser absoluto y relativo a la vez, plenitud y carencia, ser y nada. Querer ser santo es querer lo imposible. Lo imposible para Genet es el Bien.

Genet quiere ser santo porque quiere el Bien, que es imposible dentro de su situación humana. El Bien es lo absoluto, pero se le encontró robando. No puede ser absolutamente bueno. Entonces hará el mal. Pero tampoco puede ser absolutamente malo. Como su acción es la maldad, se convierte en mártir de sí mismo, en santo.

Es santo porque se re-crea dándose a sí mismo sus leyes; será el mártir del mal, el mártir del robo y del crimen porque transfiere su vida a una pura interiorización.

Es mártir porque, a pesar de haber querido el Bien (por ello quiere ser santo), hace el Mal, lo que interiormente para él significa un sacrificio. En esto consiste su acción porque:

"para Genet, el fin del hombre no es el hombre (...) es destruir en sí el tiempo, la historia y lo humano para que nazca en el instante el reino de lo eterno y de lo divino (...) Genet sacrifica al mundo y a sí mismo para tener acceso al universo de lo sagrado".

${ }^{2}$ Ibidem, p. 230.
Su fin no es la acción en-el-mundo, sino los valores que él le da a esa acción ya interiorizada. Sacrifica su acción enel-mundo por la interiorización que implica ser mártir de sus propias acciones. Sacrifica todo para participar de "otro" mundo, de su mundo interior. Ser santo es pertenecer al mundo del En-sí. En palabras de Kant, es no estar en el mundo del fenómeno sino del noúmeno. Es estar más allá de la conciencia concreta, en lo transfenoménico, más allá de lo que se nos da a los sentidos. Es participar de un ser absoluto al que no podemos llegar mediante el conocimiento. Es participar de un ser inaccesible. Es lo que le sucede a Genet: En realidad, lo que él prueba, a pesar suyo, es que los valores religiosos están más allá y a veces en contra de la ética humana. Su acción es precisamente asumir la ética humana yendo en su contra: por ello quiere ser condenado y por ello también su acción es sacrificio. Al darse cuenta que el Mal absoluto es imposible, ya no hace el mal para ser malo sino para ser santo, para sacrificarse asumiendo una ética en la que no cree. Se sacrifica haciendo el mal sin ser malo. Por ello es mártir. Y por ello el sacrificio religioso para Genet se da también en la acción del mal.

\section{LA ESTÉTICA}

La belleza destruye al Ser-en-sí porque el arte es la creación de una "realidad" distinta de la realidad natural. 
NOTAS

Esta realidad natural, para Genet y para toda la tradición filosófica que él asume, se identifica con el Ser, con la Plenitud: En este sentido, todo arte es imitación, es querer ser pleno y no serlo. Ya desde la Edad Media, el arte es visto como secundario porque rompe con el Ser, con la Realidad, con la Naturaleza.

Por eso la belleza es apariencia. Va contra el Ser. Es el Mal, porque tanto el Mal como la Belleza son anti-physis.

Genet es, entonces, esteta para llevar el Mal a la práctica. Si la belleza destruye al Ser, entonces el malo se hace esteta.

Pero esta lucha constante de Genet contra el mundo no se da como en los demás estetas que rechąan la moral común y proclaman sus propias leyes: Genet utiliza la belleza como un arma dentro del sistema ético humano: lucha en el mundo con los mismos valores

112 del mundo. Quiere que se le condene. Acepta los valores y hace lo contrario de lo que ellos dictan. Por eso, también en este caso, es sacrificio.

\section{LA LITERATURA}

Genet parte del hecho de que la lengua es del Otro, tiene los valores que los otros le dan. Es lo que permite a Genet tener culpa frente a los otros, hacer el mal dentro de su propio campo de valores. Los pensamientos de Genet están en constante contradicción y se rechazan. Pero como las palabras sí pueden unirse, es mediante la lengua escrita que Genet lleva a cabo su verdadera acción. Es poder infinito de creación. Genet crea para permanecer en el vacío, usa la literatura para aislarse aún más de los hombres. No habla para que lo escuchen ni escribe para que lo lean. Utiliza las palabras para permanecer en la carencia, para seguir siendo un "muerto social", como dice Sartre.

Pero como en realidad se le lee, el lenguaje de Genet cumple su función de hacer el mal y a un nivel aún más profundo que sus robos y sus fraudes. Si bien un ladrón es un ser creado por la sociedad en la que se desenvuelve, pasa inadvertido como hombre concreto para convertirse en el "ladrón" o en el "criminal", producto de dicha sociedad. Pero un escritor del Mal ya no es un escritor cualquiera, producto de la sociedad. Es específicamente Jean Genet. El criminal acaba con algo o con alguien: mediante la literatura se crea, no se destruye. Al escribirse el crimen, se crea. Construye un objeto que llena las conciencias de criminalidad, que hace surgir el crimen en medio de la sociedad.

Lo peor no es hacer el mal sino manifestarlo, proclamarlo. La mayor parte de las obras de Genet tienen como tema principal el crimen. Como fiel reflejo de su ser, Genet quiere que estas obras no se publiquen, que sean leídas como algo negativo o, aún mejor, que no se lean.

Como criminal, sólo algunos policías conocen su existencia. Como escritor, su campo es mucho más amplio. Es leído, a pesar suyo, por un público más o menos numeroso: hace el mal infec- 
tando el mundo a mayor escala. Se convierte en objeto de horror. Obliga a los otros a verlo como él quiere ser visto. Ya no comete el crimen sino que da su significado y su interpretación. Es éste el verdadero mal que causa a la sociedad: porque para Genet la sociedad no es mala; es él el causante del mal. Definirá el mal por lo que él es, mostrándole así a dicha sociedad el producto que ha creado.

Por ejemplo, en Notre-Dame des Fleurs (1942-43), se muestra exactamente como él es, sin compasión ni piedad. Sus personajes se ven obligados a amar lo que odian y por ello son mártires, por ello son santos. Son solitarios, medio locos, casi esquizofrénicos.

Sus obras van desarrollándose junto con Genet: en Miracle de la Rose (1943, publicada en 1946), ya no es una pesadilla lo que narra, sino un despertar: es la liberación de Genet. De hecho, es la última vez que pone a sus personajes en prisión. Ahora lo que hace es describir la sociedad mediante un hombre astuto, nervioso. En otras palabras, podríamos decir que describe a un hombre más humano, que se pasea en su celda. Es la historia de una cierta sociedad.

Pero la obra que verdaderamente representa un cambio en la creación literaria de Genet es Pompes Funèbres (1944-45, publicada en 1947). Ésta es ya una obra de completa interiorización. $\mathrm{Da}$ a los objetos significados específicos que les permiten ser "útiles" para Genet. Todo acto es un rito, una ceremonia hacia lo negativo. Como las cosas han perdido verdadero significado para Genet, como tanto él como los objetos que maneja son para los otros, entonces no tiene importancia en qué se conviertan: así vemos una caja de cerillos convertirse en ataúd, un ataúd que contiene el cuerpo de su amante, del rencor hacia la muerte donde no existe el ser. Todo es pasado, es noser. Es una re-creación de Genet: interiorización pura.

Su obra posterior,Journal du Voleur (1946, publicada clandestinamente en 1948), ya no es una meditación sobre su vida, sino sobre sus obras mismas: es una herencia literaria que nos muestra los recuerdos que son sus obras: son primero manifestaciones del Mal; después, de la imposibilidad del Mal; de la Santidad; de la Comedia; del Sacrificio, y así sucesivamente.

Tal vez la obra que mejor refleja la personalidad de Genet es Les Bonnes (1946-1947). Es la muestra del continuo movimiento de Genet de ser y apariencia, de imaginación y realidad. Al escribirla, lo que Genet hace es mostrar lo artificial, poner la mentira en escena. Les Bonnes, las sirvientas, son los otros. Pertenecen al mundo de sus patrones. Son el no-ser, el mal. Quieren integrarse al orden social que repudian: contradicción de la vida diaria. Son como la sociedad las ha creado: falsas, producto de lo artificial; tienen siempre la conciencia de ser otras que ellas mismas. Incluso Genet hace que quienes actúen el papel de sirvientas sean hombres, para que se vea aún más falsa la situación; hombres vestidos de mujer, por supuesto. Y además trata de que no sean actores profesionales: así, 
NOTAS

son actores que no son actores, sirvientas que no son sirvientas, mujeres que no son mujeres: Todo es mentira.

\section{LA POESÍA}

La poesía en Genet no es una de las formas de literatura; es una manera que él tiene de vivir. Es estrictamente personal; no se destina a un público. El tema de sus obras es siempre aquęllo que afecta su sensibilidad. Son puramente experiencias mentales.

Si definiéramos la poesía como comunicación, Genet no sería poeta, porque incapacita sus obras para tal efecto. Genet no nos da nada en sus poesías. Se leen sin recibir algo positivo: desgarra los valores, el honor, la virtud, el bien, para no ofrecer más que vacío. Sus obras tratan de la apariencia porque escribe sus sueños. En ningún sitio hay lugar para el Ser: es solamente crimen, solamente destrucción. Es el Mal sin pretexto, sin excusa, sin justificación. Elimina su ser y se presenta como gesto.

Pero su poesía tiene, de hecho, un fin: mediante la palabra, golpear la conciencia de los otros, de la sociedad entera. Aunque trate de evitar su publicación, crea algo concreto. No escribe para ser leído, pero lo es. Sin quererlo, Genet transforma al otro que lee sus obras, deja de estar en sí mismo y se convierte en leyenda, en poesíapara-los-otros. Hace a un lado su circunstancia y ejerce su libertad.
"La idea que nunca he dejado de desarrollar es que, a fin de cuentas, cada quien es siempre responsable de lo que se ha hecho de él - aun si no puede hacer nada más que asumir esta responsabilidad. Yo creo que un hombre siempre puede hacer algo de lo que se ha hecho de él. Es la definición que daría yo hoy de la libertad: ese pequeño movimiento que hace de un ser social totalmente condicionado, una persona que no restituye la totalidad de lo que ha recibido, de su condicionamiento; que hace de Genet un poeta, por ejemplo, mientras que estuvo rigurosamente condicionado para ser un ladrón (...) Porque a Genet se le hizo ladrón; él dijo 'soy un ladrón' y ese pequeño movimiento fue el principio de un proceso mediante el cualllegó a ser poeta $y$, después, finalmente, un ser que ya no está verdaderamente al margen de la sociedad, alguien que ya no sabe dónde está y que se calla. En un caso como el suyo, la libertad no puede ser dichosa: No es un triunfo. Para Genet, simplemente abrió ciertos caminos que no le habían sido ofrecidos desde el comienzo." 3

Nota: La traducción de las citas es responsabilidad de Marcela Cinta.

${ }^{3}$ Sartre, cf. en Francis Jeanson, Sartre dans sa Vie, París: Éditions du Seuil, 1974, p. 264. 


\section{RESEÑAS}

Luis Astey, Dramas litúrgicos del Occidente Medieval, * 1992, México, El Colegio de México-Consejo Nacional de Ciencia y Tecnología-Instituto Tecnológico Autónomo de México, 682 p. ISBN 968-12-0544-8

Hoy estamos a punto de presenciar la clausura del segundo milenio cristiano, evento que sólo sucede en una de cada treinta generaciones. Nos ha tocado a nosotros, como les tocó hace treinta generaciones a otro grupo de hombres y mujeres, en un período que por no encontrar un mejor nombre con qué bautizarlo hemos llamado Edad media o Medioevo. Hoy nosotros somos testigos de la metamorfosis de una época histórica en otra, la nuestra partió del Renacimiento y hoy parece que llega a su término. Ignorantes somos de lo que seguirá, únicamente podemos atestiguar transformaciones que sobrepasan a todo lo que la ficción pudiera imaginar con su fantasía febril. El período que vendrá ha sido bautizado de Posmodernismo, porque tampoco hemos encontrado un nombre adecuado; así como desacertadamente se califica de Edad Media a la etapa que une la Edad Antigua con el despertar del Renacimiento.

Estudiar las personas que nos antecedieron por mil años de historia es acaso imaginar, a lo Borges, que otros humanos nos estudiarán dentro de diez siglos y encontrarán seguramente que nuestro siglo no fue el más pleno de la historia. Acaso alguno de los que nos seguirá alcanzará la plenitud y la totalidad en todos los sentidos; y seguramente los humanos del futuro determinarán que alguna otra etapa anterior a la nuestra fue mayormente excelente.

¿Qué tiene que ver todo esto con un libro sobre dramas litúrgicos, publicado por un investigador-traductor jalisciense? Para enlistar los méritos de la edición no sólo tengo que hacer referencia a una larga lista de merecimientos, sino al

* Premio Nacional a la mejor edición universitaria Arnaldo Orfila Reynal, en la categoría de Libro de Humanidades. 


\section{RESEÑAS}

hecho de que el estudio del profesor Astey posee más méritos y mayor oportunidad de lo que a primera vista pudiéramos pensar.

Por primera vez se presenta en lengua castellana una edición integral de media centena de dramas litúrgicos con que cuenta nuestro bagaje de piezas litúrgicas medievales en el mundo occidental. La pieza más temprana es el Quem queritis, que en la versión de la catedral de Verona puede ser fechada en el inicio del año 900 . Si recorremos con la memoria lo que sucedió mil años después en el teatro mundial, podemos observar una plétora de dramaturgos que invadieron la escena europea: Henrik Ibsen, con su drama de liberación burguesa; August Strindberg, primero con sus experimentos naturalistas y después con uno de los más atrevidos ejercicios dentro del expresionismo. Jacinto Benavente europeizaba el drama español; Edmond Rostand alcanzaba uno de los triunfos más duraderos del romanticismo con Cyrano de Bergerac; mientras el teatro moderno nacía con $U b u$ roi, de Jarry, en 1896 , en representaciones que parecieron fracasadas en su primer intento, a pesar del vestuario y las máscaras diseñadas por el autor y por tres pintores hoy inmensamente reconocidos, Toulouse-Lautrec, Bonnard y Vuillard.

El segundo drama litúrgico presentado en el libro es la Visitatio sepulchri, que es ofrecido en siete versiones primarias y en otras tres posteriores; la primera pertenece a Winchester, Inglaterra, se halla en la Regularis concondia y está fechada aproximadamente en 970; y la última es la versión de Praga, del siglo XIV. Mil años después de la versión de Winchester tuvimos una crisis mundial por falta de dramaturgos. El drama alemán propuso la reubicación de lo dramático en lo testimonial con Peter Weiss y en el extremo del expresionismo con obras de Rainer Werner Fassbinder y de Peter Handke. Mientras que en Hispanoamérica se estrenaban varias de nuestras mejores piezas: Un niño azul para esa sombra, del puertorriqueño René Marqués; Flores de papel, del chileno Egon Wolff; y Los viejos, de nuestro querido Rodolfo Usigli.

Otros dramas pascuales o relacionados, contenidos en el libro del profesor Astey son el Ordo Paschalis, el Officium pregrinorum, el Oficio de la Ascención y el Oficio de Pentecostés, que van del siglo XII al año 1532, presentados en el texto con 11 versiones diferentes.

Del ciclo de Navidad, el libro nos ofrece cuatro piezas litúrgicas en 17 versiones, conservadas en catedrales tan conocidas como Rouen, Estrasburog, Laon y San Pedro de Beauvais. Esta última fue el edificio más elevado construido en la Edad Media, pero sus alturas lo traicionaron y se cayó pocos años después; hoy permanece un muñón catedralicio que todavía escalofría a quienes lo hemos visitado porque es, al menos para mí, un símbolo de la Edad Media. La catedral de Beauvais guarda grandes riquezas en manuscritos antiguos.

En la última parte del libro se presentan tres dramas semilitúrgicos, el Ludus de Nativitate, del siglo XIII, el Danielis ludos, de la Catedral de Beauvais, del 


\section{RESEÑAS}

siglo XII, y el Sponsus, de la iglesia de Saint Martial, en Limoges, perteneciente al siglo XI.

Aunque parezca un imposible, la herencia del teatro medieval aún está con nosotros; estos dramas litúrgicos pertenecen a dos géneros dramáticos, al auto, que puede ser litúrgico, especialmente de la Natividad y la Pascua, o a la farsa, verdadera creación dramática que nace en el Medievo y que hoy parece constituirse en el género por antonomasia para el siglo que está por nacer. Las cincuenta obras presentadas pertenecen al auto, pero por momentos aparece la farsa cuando se desvía la trama de la apuntada por los Evangelios. Así, la farsa medieval plena de juegos y, posteriormente, la Comedia dell'Arte están aún hoy presentes en nuestra farsa moderna de Ubu roi, de Alfred Jarry, y Fin de partida, de Samuel Beckett. Los mismos dramas litúrgicos dejaron honda huella en el teatro posterior. El género del auto, sea sacramental, bíblico o hagiográfico, ha tenido seguidores en el siglo XX; recordemos los dramas cristianos de Paul Claudel y de Henry de Montherlant. La frase "Nada hay nuevo bajo el sol" podría ser expresada por una consideración que para muchos de ustedes pudiera parecer inexacta: "Nada teatral que sea moderno, deja de tener algo medieval." Me atrevo a decir una blasfemia teatral: podemos dejar de lado el teatro renacentista y aún así poder explicar la aparición de Shakespeare y de Calderón de la Barca, pero nunca podemos olvidar que hubo un teatro medieval que, al menos en los dramas litúrgicos presentados en el libro, va del siglo $\mathrm{X}$ al año de 1532.

Para comprender el destino teatral con que se abre el teatro que un día iba a llamarse mexicano, habría que señalar las influencias literarias y teatrales que sirvieron de materia prima para crearlo. Existen discrepancias en la documentación de la primera representación teatral en México. García Icazbalceta la fija el día de Corpus Christi de 1528, según consta en las actas del cabildo de ese año, que registran la solicitud de cesión de un solar de donde "saliesen sus oficios". Sin embargo, Usigli afirma que "a pesar de todo, nada aparece aún claramente con relación a las representaciones", y señala la del 20 de junio de 1538 como la primera representación en castellano citada por las crónicas, sin negar que hubiera otras anteriores de las que no tenemos noticia. Knapp Jones difiere dé los anteriores, y sugiere la representación en náhuatl de "El último juicio", referida por Motolinia en su Historia de los indios de la Nueva España, llevada a cabo en 1533 y con la posible autoría de Fray Andrés de Olmos (1491-1571). Por nuestra parte aceptamos el año de 1533 para la primera representación teatral en la Nueva España, por lo que el teatro en la geografía mexicana cuenta con una tradición de más de 450 años. Así que la primera pieza representada en los límites geográficos que hoy llamamos México fue un drama litúrgico de la Natividad, un año después del último drama presentado como medieval por el profesor Astey, el Oficio de Pentecostés, existente en la Cole- 


\section{RESEÑAS}

giata de la Halle y Fechado en 1532. Así que a un año de morir el teatro litúrgico medieval, nacía el teatro mexicano.

Ya antes de que el profesor Astey publicara el presente libro, nos había ofrecido un banquete del teatro medieval, aunque no estrictamente litúrgico, como las incomparables obras que él mismo ha editado en castellano de Hrotsvitha de Gandersheim, una religiosa del siglo X que escribió los mejores dramas no sacros, estrictamente hablando, porque la ficción roba el equilibrio dramático a los santos documentos. De esta escritora germana únicamente seis dramas han llegado hasta nosotros, pero son suficientes para comprender su genialidad. Es la única mujer-dramaturga que puede compararse con sor Juana Inés de la Cruz, autora de tres autos, de tres comedias y de numerosas loas y villancicos dramáticos, que coincidentemente están muy influidos por el teatro medieval.

¿En qué autores modernos se ve la huella del teatro medieval? Habría que mencionar al belga Maurice Maeterlinck, al francés Paul Claudel, y al teatro épico de Bertolt Brecht - que se llama épico porque es contado, como las baladas medievales o como ahora lo hacen los corridos mexicanos. El fársico ha sido el género por antonomasia del teatro moderno, y aunque debemos reconocer que aunque parte de la comedia griega y romana, fue el teatro medieval quien le dio carta de ciudadanía.

Otro aspecto que hay que tener en cuenta para respetar el contenido y los sabios comentarios del profesor Astey es el hecho de que el teatro medieval recorre cuando menos seis siglos, mientras que el que llamamos moderno apenas lleva unos cuatrocientos años. Valga como ejemplo los cuatro siglos de las siguientes obras de Shakespeare: The Comedy of Error, The Two Gentlemen of Verona y-The Taming of the Shrew y de las tragedias Titus Andronicus y Richard the III. En muchas obras del siglo de oro español aparecen geografías medievales, con fechas no especificadas pero con valores que hoy calificamos de medievales. Lope recurre en muchas ocasiones al Medievo, si no al tiempo, al menos a los valores de la sociedad que presenta, como lo señalan algunas de sus mejores piezas, entre otras, Fuente Ovejuna y El caballero de Olmedo. Los dramas litúrgicos o autos de Calderón de la Barca, y por consiguiente de Sor Juana Inés de la Cruz, no pudieron ser escritos sin los Dramas litúrgicos presentados en el libro del profesor Astey.

Qué interesante resulta el comentario de que no se puede diferenciar el drama litúrgico noble del plebeyo, porque así como podemos apuntar otros dramas indiscutiblemente escritos para ser representados exclusivamente en la corte, no podemos encontrar dramas medievales o renacentistas escritos para ser representados sólo ante las cortes, sino que siempre son cristianamente socializados - aún no podemos calificarlos de demócratas - porque estos dramas litúrgicos eran igualmente vistos por reyes y pordioseros. 
RESEÑAS

En los dramas litúrgicos europeos podemos encontrar los primeros vestigios de cómo escribir teatro. Los personajes y las acotaciones algunas veces no están bien diferenciados, y el resultado es una forma híbrida entre la narrativa y el teatro. Como ejemplo veamos una acotación: "Después de esto, Herodes sea roído por gusanos y, siendo retirado de su sitial, muerto, sea tomado por los diablos, que se regocijan enormemente. Y la corona de Herodes sea colocada sobre su hijo Arquelao" (625). Qué maravilla de escena podría crear un director del siglo XX con este final de obra.

Para tener una cabal ideal del impacto que estas cincuenta piezas tuvieron en el ánimo del pueblo medieval, hay que pensar en los medios de producción, que resultaban inusitados para la Edad Media: desde el lugar interior de la iglesia hasta la plaza central de la población, o en un teatro de origen romano. Una de las atracciones eran los animales exóticos - de los que sobreviven testimonios en las pinturas de Van Alsloot de Bruselas - junto a máscaras fantásticas que desviaban la atención del público hacia otros niveles de percepción, hacia un mundo metateatral habitado por seres teatrales, reflejo irónico y paródico de nuestra humanidad.

El interés por el teatro medieval no ha sido únicamente de profesores e investigadores, sino que ha vuelto una y otra vez a la escena, como las puestas de York y Chester, en Inglaterra, y recientemente las de Toronto. En Inglaterra existe un grupo de Medieval Players (Actores Medievales), y el Teatro Nacional Británico ha tenido enorme éxito en las adaptaciones de Tony Harrison del ciclo llamado The Mysteries (1985). Asimismo existe la Societé Internationale pour l'Etude du Theatre Mediéval. Yo he sido testigo del Corpus Christi que se lleva a cabo cada año en la ciudad de Valencia. Me escapé unas horas de la Reunión de Intelectuales y Artistas que celebró los cincuenta años de la reunión antifascista llevada a cabo en plena guerra civil española, para observar desde la torre de la catedral y desde la calle el desfile de la custodia y de los personajes metateatrales que desde el Medievo siguen visitando esa ciudad española. Nuestras pasiones y representaciones populares semisacras son también remanentes de los dramas litúrgicos del mundo medieval.

El nuevo amanuense y traductor del libro que hoy presentamos es Luis Astey Vázquez, nacido en Guadalajara y titulado de abogado en la Universidad Autónoma de Guadalajara. Su experiencia docente se inició en 1945 en el Instituto Tecnológico y de Estudios Superiores de Monterrey, donde colaboró en la época dorada del área humanística de esa institución, bajo los auspicios intelectuales de don Alfonso Rubio y Rubio, hasta 1973. Alli conoció a Manuel Rodríguez Vizcarra, quien descendía de una ilustre familia terrateniente colonial en lo que hoy es el Estado de Jalisco. Rodríguez Vizcarra editó al profesor Astey varios libros de Poesía en el Mundo, como el volumen 46, 73, 80, 91 y 130, en una de las colecciones más importantes de la provincia mexicana (donde me 


\section{RESEÑAS}

precio de tener dos libros: Nuestro señor Quetzalcóatl y La catedral humana. Esta última de mis piezas sucede, coincidentemente, durante el siglo XII y relata la construcción y caída de la catedral de San Pedro de Beuvais). Entre estas ediciones del profesor Astey descuella la del Pergamino Vindel, un hallazgo medieval de primerísima importancia. Posteriormente, el profesor Astey ha colaborado con la UNAM, con el Instituto Tecnológico Autónomo de México y con El Colegio de México.

Indiscutiblemente el profesor Astey con su magnífico libro nos obliga a reconsiderar el teatro medieval, y sobre todo a buscar y rebuscar lo que de medieval seguimos teniendo en Guadalajara, por ser parte de un país donde el tiempo vuela al siglo XXI mientras se encuentra aún aherrojado a otros tiempos de la historia, para bien de nosotros y del futuro, claro, porque nos permite todavía ser humanistas cuando la tecnocracia nos persigue. Las ubicuas pastorelas que nuestra ciudad tiene y que este año llegaron a tener hasta un certamen para seleccionar la mejor, parten de los dramas litúrgicos de la Natividad que están presentados en sus orígenes en el libro del profesor Astey; la importancia de la Semana Santa y de la Pascua no han llegado hasta nosotros con el teatro, pero sí como fiestas que hay que guardar; las peregrinaciones zapopanas son ecos de Medievo religioso que convertían la búsqueda de la escala celestial én una fiesta mundana, tan bien ejemplificada por Talpa, de Juan Rulfo, en un mundo actual que todavía conserva matices medievales, como en Al filo del agua, de Yáñez, y Pedro Páramo, también de Rulfo.

Este libro con sus 682 páginas es un atentado al ocio mexicano, que invita a

120 la molicie, y un homenaje al ocio griego, que invita a las labores del pensamiento. Así como podemos contar diez centurias de teatro medieval, también podemos contar orgullosos con casi cinco centurias de teatro hispánico en nuestro México. ¿Verdad que esta comparación nos hace reconsiderar el teatro medieval, sin que lo veamos únicamente de interés bibliográfico? En conclusión, el teatro medieval, tanto el secular como el litúrgico, está vigente hoy entre nosotros porque, para bien de México, ni el período protomexicano ni el colonial han desaparecido, y con ellos han quedado la idiosincrasia y muchos valores de lo que hoy llamamos Edad Media, pero que fue, desde mi perspectiva, una de las edades más plenas de la historia.

\section{GUILLERMO SCHMIDHUBER DE LA MORA, PHD Centro de Estudios Literarios Universidad de Guadalajara}




\section{RESEÑAS}

Edgardo Enríquez Froeden, En el nombre de una vida, México, UAM-X; 1994, 3 tomos, xxxp, ISBN 970-620-481-4

No pretendo hacer una reseña ortodoxa que dé cuenta de la calidad literaria o de la fidelidad histórica del autor; quiero dar a conocer este testimonio para que sea tomado en cuenta como el relato de la vida fructífera, digna, honesta y limpia de un hombre que no oculta que ha vivido y se ha involucrado apasionadamente con las causas más justas del pueblo chileno.

Estas memorias están escritas por Don Edgardo en una doble dimensión. Por una parte, su propia y - en mi concepto - extraordinaria existencia, esculpida con fuerza y consecuencia en la lucha por principios que son más fáciles proclamar que practicar. Él es un ejemplo de humanidad. Tan humano que no se permite en sus recuerdos olvidar de dar cuenta de sus pasiones, errores y rencores, algunos de los cuales compartimos con distinta intensidad numerosos chilenos. Por otra parte, son un jirón de la historia de Chile; para ser más precisos, una importante parte de la historia de Concepción (ciudad de industria y cultura, y por tanto de lucha y contradicciones, ubicada a unos quinientos kilómetros al sur de Santiago), donde desarrollará la mayor parte de su productiva vida, que deseamos continúe aún por mucho tiempo.

En mil cuatrocientos treinta y siete páginas nos cuenta de una época, de un país, de los sueños colectivos e individuales que entretejidos van formando la historia, el presente y el posible futuro de una nación, y en medio de la urdimbre de esperanzas, él, construyendo la propuesta principal de su vida: ser maestro.

Es en su vocación docente donde se percibe con mayor claridad la dimensión humanista de Edgardo Enríquez, como profesor y luego primer rector, electo por la comunidad, de la Universidad de Concepción. Es allí donde se puede observar su función principal de maestro, en el salón de clases, en la palabra, en el ejemplo de una vida. Bajo sus mismos principios crió cuatro hijos que respondieron a su enseñanza, dos de ellos pagaron con la vida su aprecio por la libertad y la justicia en los crueles años de la dictadura pinochetista que azotó a Chile entre 1973 y 1990. 


\section{RESEÑAS}

El relato de una vida tan caracterizada por la lucha y la honestidad pudiera hacer sospechar al lector que desconozca la trayectoria de Don Edgardo, que prevalece una tendencia a exagerar sus roles protagónicos. Para evitar esta sensación es necesario señalar que la mayoría de los hermanos Enríquez Froden ocuparon lugares destacados en la academia y en la política en Chile; todos tuvieron reputación de honestos, honor que en los días en que vivimos no es despreciable. Edgardo Enríquez ha manifestado además otro mérito extraordinario, no callar ante el poder o la autoridad cuando se comete una injusticia contra su persona o la de otros.

El relato en estas memorias nos da cuenta de muchos enfrentamientos contra actos injustos, por arbitrariedad o error, como el hecho que quiero destacar como ejemplo, que hoy es anécdota, pero en su momento tiene que haber tenido tintes casi trágicos. Cuenta en la página 254 del tercer tomo, que siendo "prisionero de guerra" de la junta de Gobierno encabezada por Pinochet, "un día de sol y calor en que fui a la comandancia a reclamar por algo, el comandante, que estaba me preguntó: y a usted ino le molesta la corbata?..." - a lo cual él respondió - "verá usted comandante, aquí lo que menos me molesta es la corbata". Hay que señalar que él, junto con un grupo de prisioneros, se encontraba en una inhóspita isla del sur de Chile en condiciones infrahumanas y que sus carceleros - personal de las fuerzas armadas - tenían como objetivo quebrar la moral y dignidad de los detenidos.

Don Edgardo en su narración nos habla de su condición de masón practicante durante gran parte de su vida, por la cual aprendería una de las virtudes más importantes de su personalidad: la tolerancia. Jamás fue un jacobino pero sí un hombre de principios. Señalo esto para que se comprenda mejor el relato de otro hecho protagonizado en el campo de concentración. Después de más de un mes como prisionero pide un sacerdote, lo que causa la extrañeza y la negativa del jefe del campo, quien conoce su calidad de masón: "tráigame entonces al venerable maestro de mi logia", demanda Don Edgardo, a lo que el otro responde, "imposible". Entonces invoca leyes tanto nacionales como internacionales para reclamar que no le pueden negar este derecho. Días después llegó un capellán y este encuentro refleja la estatura moral de un hombre digno. Le relata al extrañado sacerdote que lo ha solicitado porque por primera vez en su vida está empezando a odiar, "y yo no quiero odiar", le confiesa. Las condiciones a las cuales ha sido reducido con los suyos conduce a este hombre generoso al odio, pero él reniega de este sentimiento; la constatación de esa grandeza humana de enfrentar la tentación de odiar al carcelero y a sus jefes, lleva al sacerdote hasta las lágrimas. Fue a través de este representante de la Iglesia católica, que se supo dónde se encontraban los más importantes dirigentes del gobierno derrocado, además de otros cientos de prisioneros de la zona, y fue el 


\section{RESEÑAS}

inicio de la digna y fructífera labor de la "Vicaría de la solidaridad", de defensa de los perseguidos cuando en Chile reinaba el terror.

Expulsado del país por la junta militar, vive un tiempo en Inglaterra, donde será constante portavoz para la denuncia de los crímenes perpetrados por la dictadura. Su interés en aproximarse a la patria y la generosidad del pueblo mexicano lo traen a este país, donde se reincorpora a sus actividades docentes y se une a la resistencia contra Pinochet.

En México continuará dedicando importantes años a la educación. Varias ' generaciones de jóvenes estudiantes de medicina de la UNAM recibirán sus enseñanzas, y él, el fuego revitalizador que aportan los estudiantes a los viejos maestros. Sin embargo, Chile lo reclama, y en pos de ese llamado vuelve a su país, donde continúa su lucha por el esclarecimiento de los hechos que provocaron el asesinato y la desaparición de miles de compatriotas, entre los que se cuentan dos de sus hijos.

La historia reciente de Chile todavía está por escribirse, pero no podrá estar completa sin incorporar relatos como el que aquí comentamos.

\section{PATRICIO SEPÚLVEDA \\ Depto. Académico de Estudios Generales, ITAM}




\section{RESEÑAS}

Eduardo Milán, Resistir. Insistencias sobre el presente poético, 1994, México, Conaculta, 200 p. ISBN 968-29-6200-5

\section{La ergástula es oscura, pero no te arredres...}

(Georgie dixit)

No es necesario ser cabalista graduado para sospechar que alguien que se nombra con apellidos en concatenación intertextual está predestinado a las insistencias, como Milán Da Milano. Su libro, como el asedio a Jericó, procede por giros cada vez más estrechos en torno de lo mismo. Es que si no se torna sobre lo mismo es un errar sin retorno, y la ida va de vuelta si la podemos versar; las variaciones serán sobre el mismo tema o no serán sino sustituciones, divagaciones u otras peregrinas mociones. Esto ya lo sabía Bach, que para disimular tuvo la ocurrencia de llamar fugas a sus obsesivas recurrencias.

"Escribir es una condena" decía Rulfo, condenado además a romper lo escrito, es decir a resistir, a no soltar palabra, a no insistir vanamente, a no abundar sobre lo dicho; sobreponiéndose - seguro con excesivo escrúpulo - a la epidemia de logomaquia anémica que seca el seso. Es que los poetas de verdad, han sido tocados con el bendito don de la palabra, pero a diferencia del común de los mortales, no pueden hablar de cualquier cosa; fungen como dueños de la palabra, pero en realidad fingen, la tienen empeñada, sólo son sus testaferros. Por eso este guardián de la frontera que milita en el límite entre lo no dicho y lo decible, aun cuando se empeña sólo en hablar de poesía, imaginaria alerta al milagro de la palabra verdadera, no puede limitarse de hacer poesía.

"Lo que queda es obra de los poetas", reconocía Heidegger. Y Milán, ante la devastación, el simulacro y la impostura relativa ambiente, con un farol que recuerda al de Diógenes, desanda un itinerario histórico, geográfico y existencial, para relevar algunos síntomas, gérmenes y secuelas: "En un artista la crítica al mundo desprendida de la crítica a su propio arte es un juego irresponsable, 
RESEÑAS

imbécil." Porque la vida es juego, por supuesto, pero no chacota. Ni la mera inquietud acción, ni cualquier garabato escritura.

Resistir para Milán es hacerse fuerte, pero no resistencia al cambio, sino a la inerte inercia; es hacerse leve, pero no resistencia pasiva, sino vigilante escucha a la voz del aura. Resistir no es dejarse estar sino echarse a andar, errar. Errar es humano, demasiado humano, pero cuando el errante se conoce en su errar, su senda es divina, no está perdido, sólo anda demorado, haciendo tiempo, rastreando algún hilo de voz, buscando para volver. (Como Almotasim, que vislumbra el aura donde fuera su punto de partida, al cabo de rondar una vida.)

Sólo el error es demostrable - enseñaba Popper - y reconociéndolo podemos acercarnos a la verdad, incierta, inasible, inefable. Sólo errando es posible exilarse de lugares comunes, lugares vacíos poblados de ecos, hacer oídos sordos a los falsos poetas, rebelarse, contradecir, revelar sonidos más ciertos, proscribirse y prescribir.

"Escribir es siempre plantearse una estética de negación de la propia vida, reafirmar una suerte de no seguimiento. Deteniendo la duración, escribir es resistir." Este celo que Milán cultiva midiendo sus propias palabras, naturalmente se vuelve discreta denuncia de los escuadrones de la muerte del verbo que fusilan a mansalva sin juicio previo.

"Escribir es siempre un acto de transgresión de las propias imposibilidades... por eso resulta un llamado de atención la 'facilidad' con que escriben los poetas de hoy en día. Se diría que todo les resulta accesible."

El responsable de la escritura es el género lejano de una especie virtualmente extinta; inautenticidad, autocomplacencia y un insaciable afán de novedad hacen de éste, "el tiempo del mimetismo" dice Milán, "donde "hacer de cuenta que se es' equivalente a ser". Se refiere a esos estériles amanuenses solipsistas como Onán - precursor de toda virtualidad - que pluma en mano maquilan una "estética de la repetición", "sin riesgo, sin aventura y sin ninguna pasión".

Pero una poética narcisista, amanerada y convencional hasta en sus transgresiones, "capaz de inventarse todas las coartadas para eludir el pensamiento y el encuentro del hombre consigo mismo a través de la manifestación estética", en realidad es una expresión servil y legitimadora. "Lo que ha ocurrido realmente, aunque en apariencia resulte lo contrario, es una nueva sumisión del arte al estatuto social, frente a una sociedad del desencanto y del simulacro, un arte igualmente desencantado y simulador."

El'desgraciado reciclado donde "vale-todo... niega, esencialmente, la experimentación y el rigor", pues la permisividad total es insignificante, equivale a la represión absoluta de la autocensura, que inhibe la creación audaz de la auténtica originalidad. Guiños, complicidades y el artificio insustancial e insulso de un recalentado de letras, son síndrome de un arrancamiento de todo centro que ha sido también un desarraigo en el tiempo. "La falta de tensión del presente es 


\title{
RESEÑAS
}

lo que ha motivado al retorno a las formas y los contenidos del pasado. La estética del revival y del remake son síntomas evidentes de una necesidad temporal de lazo con el pasado, posibilitada por la emergencia de todos los tiempos que habían sido ahogados por la visión evolutiva y lineal de la historia."

El artista, como el individuo actual, junto con la memoria "ha perdido la capacidad de trascenderse". Desde el Renacimiento, remontar a abrevar en las fuentes ha sido un movimiento perpetuo del arte occidental y sobre todo durante el siglo pasado, pero nunca como en el presente ese recurso se había efectuado de manera tan irreflexiva, dando lugar a una insólita operación de vaciamiento de sentido. El autor se pretende poeta que regresa al útero, en realidad sólo se mira el ombligo.

Resistir al nihilismo con una insistencia que no es desvarío sino errar encaminado a la búsqueda del sentido; porque el futuro será poético o no será: "Cuando la razón y la verdad entran en cuestionamiento la que verdaderamente debe alterarse es la poesía, dada su condición de puente hacia la verdad o de otro respecto de la razón."

Parecen variables, pero en una ecuación vital cuya representación es una trayectoria donde el movimiento se demuestra errando para volver a dar en el centro, resistir, insistir y existir son tautologías constantes. Para los poetas, las oposiciones totales son falsas apariencias o mejor, auténticos secretos a voces; coicidentia oppositonum, la serpiente se ha mordido la cola: admirable caso de un hombre de palabra el de Milán, que literalmente cuando resiste no se amilana.

\author{
ALBERTO SAURET \\ Departamento Académico de \\ Estudios Generales, ITAM
}




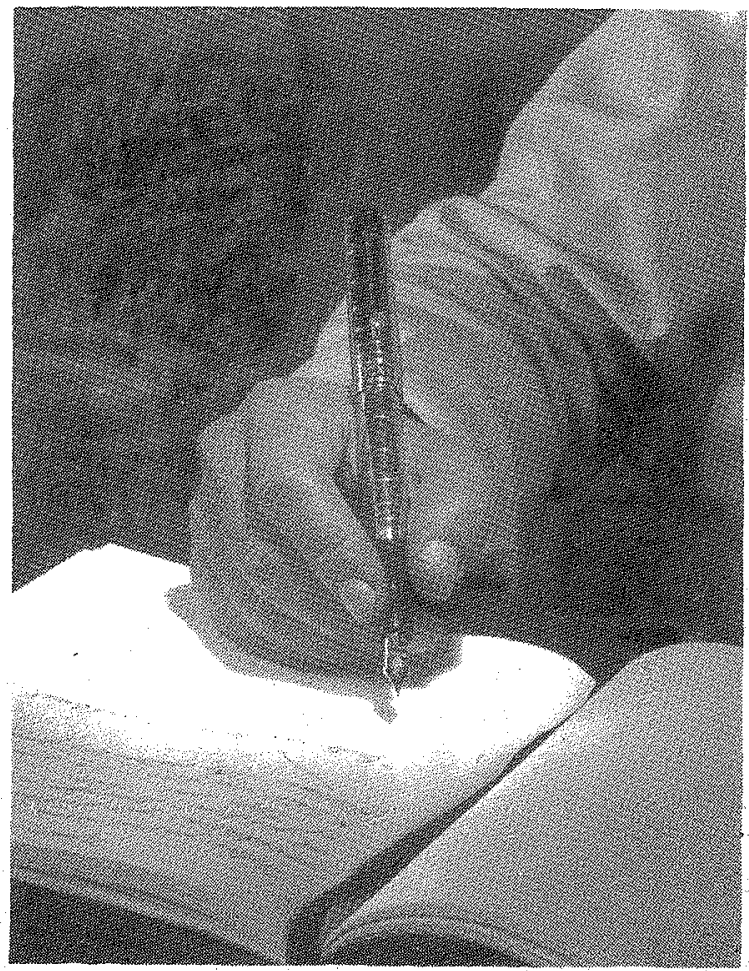

porque tenemos el valor de enfrentar una hoja en blanco...

en unomásuno tenemos un compromiso con nuestro lector, por eso le ofrecemos todo un año de información con el más detallado análisis desde diversos puntos de vista, por sólo 200 nuevos pesos...

\section{i i i suscribase al 563-99-1 1 !!!}

\section{unomásuno Lectura inteligente.}



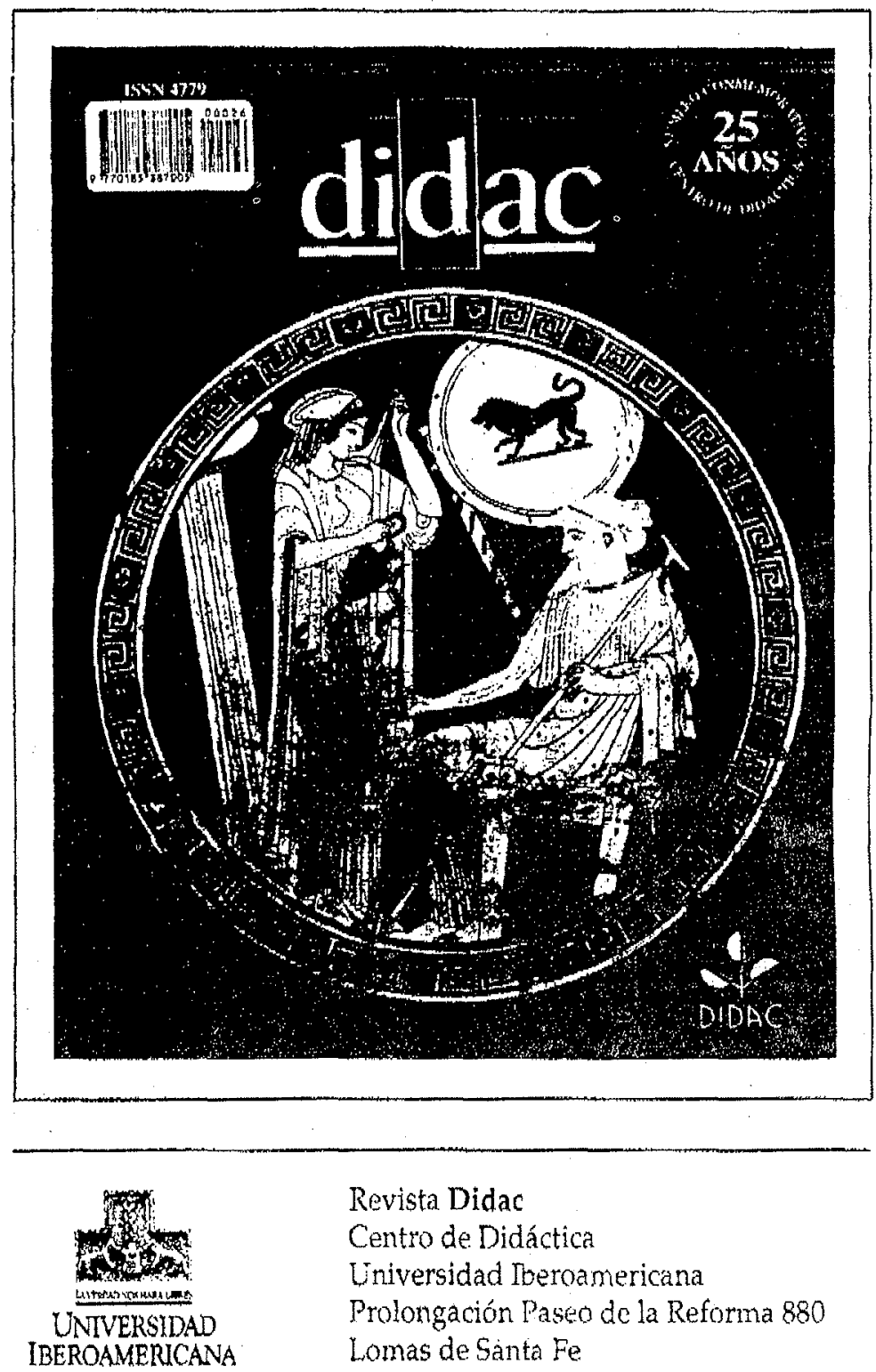

Revista Didac

Centro de Didáctica

Universidad Iberoamericana

Prolongación Paseo de la Reforma 880 Lomas de Santa Fe 01210, México, D.F.

Ejemplar:

$\mathrm{N} \$ 10.00$

Números atrasados: 12.00

Suscripción anual: 20.00

Suscripción bienal: 30.00 


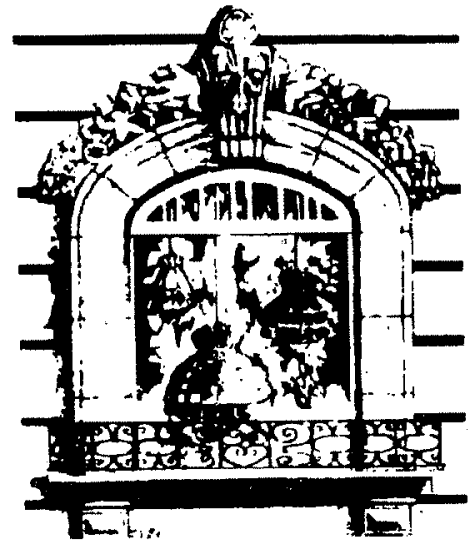

LA CASA DE Reservaciones: Vucatatia y Cazhuila. $\overline{C A N T E R A}$

Tels. $584-7597$ y $584-3825$

\section{EN NOVTEMBRE

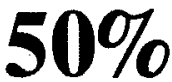

DE DESCUENTO

SÓLO EN ALIMENTOS Y PAGANDO EN EFECTIVO MÁS I.V.A.

- GRAN BUFFET• DE MARISCOS

Cortes de carne tipo americano

Comida internacional y mucho más...

* MÚSICA VIVA PARA BAILAR*

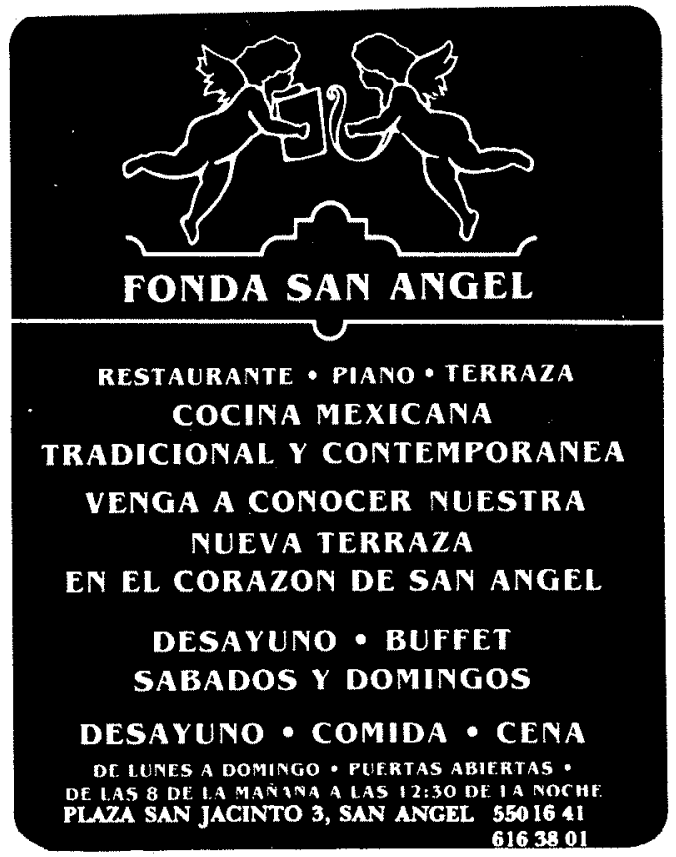




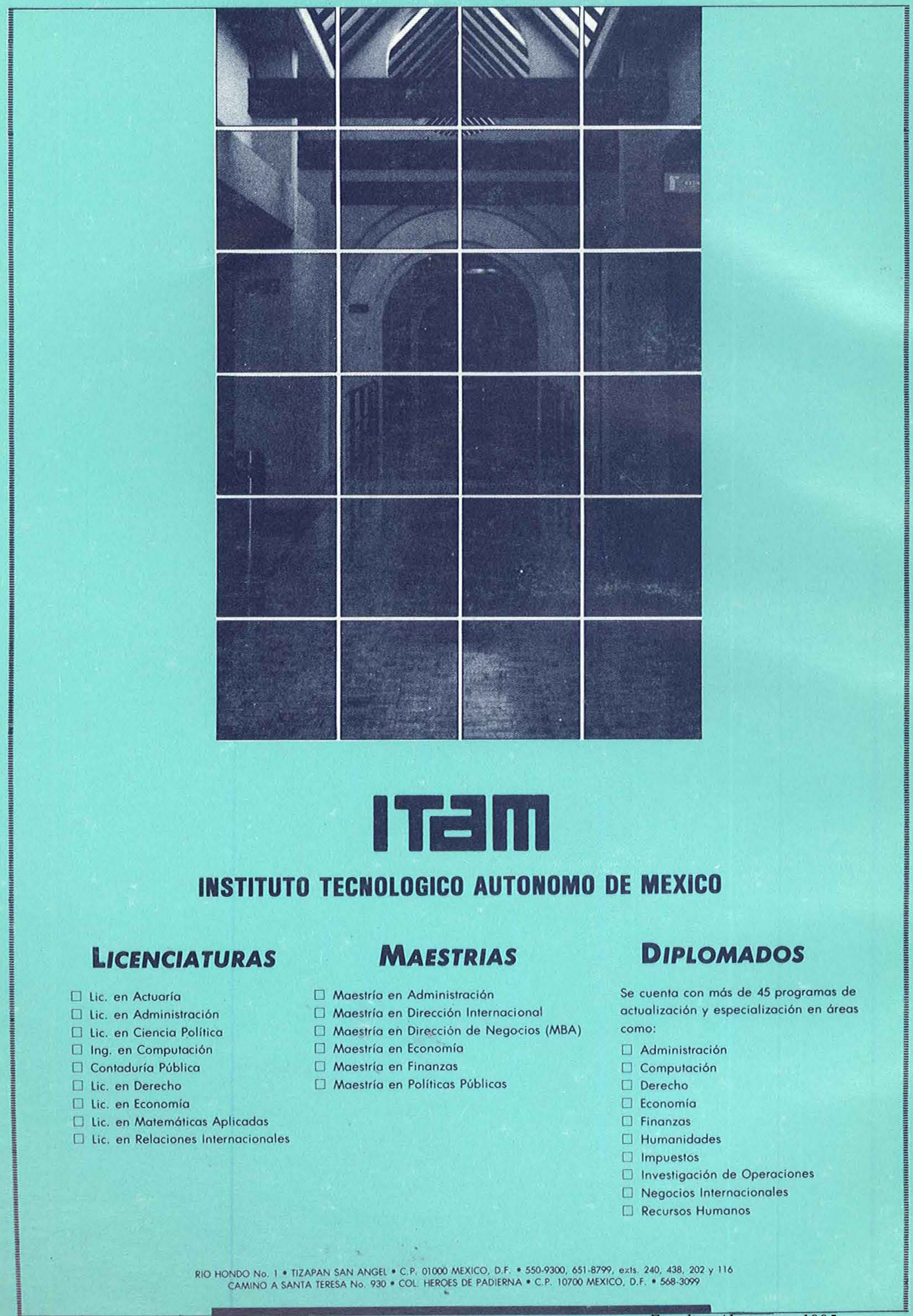

